\title{
ADUBAÇÃO BORATADA EM POMAR DE LARANJA PÊRA RIO AFETADO PELA CLOROSE VARIEGADA DOS CITROS
}

\author{
ISABELA RODRIGUES BOLOGNA
}

Dissertação apresentada à Escola Superior de Agricultura "Luiz de Queiroz", Universidade de São Paulo, para obtenção do título de Mestre em Agronomia, Área de Concentração: Solos e Nutrição de Plantas.

P I R A C I C A B A

Estado de São Paulo - Brasil

Maio - 2003 


\section{ADUBAÇÃO BORATADA EM POMAR DE LARANJA PÊRA RIO AFETADO PELA CLOROSE VARIEGADA DOS CITROS}

\section{ISABELA RODRIGUES BOLOGNA}

Engenheiro Agrônomo

\section{Orientador: Prof. Dr. GODOFREDO CESAR VITTI}

Dissertação apresentada à Escola Superior de Agricultura "Luiz de Queiroz", Universidade de São Paulo, para obtenção do título de Mestre em Agronomia, Área de Concentração: Solos e Nutrição de Plantas.

P I R A C I C A B A

Estado de São Paulo - Brasil

Maio - 2003 
Dados Internacionais de Catalogação na Publicação (CIP) DIVISÃO DE BIBLIOTECA E DOCUMENTAÇÃO - ESALQ/USP

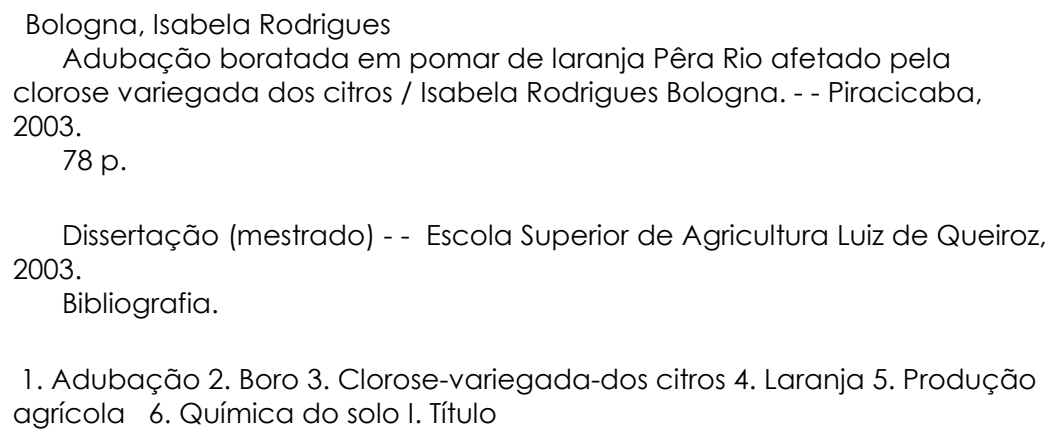

CDD 634.31

\section{"Permitida a cópia total ou parcial deste documento, desde que citada a fonte - $\mathrm{O}$ autor"}


Aos meus pais,

Renato e Lúcia Helena, pela oportunidade da vida e alimento da alma

OFEREÇO.

Aos meus irmãos,

Marcio e Samantha, pela honra da convivência e ajuda nas escolhas da vida;

Ao Adriano, pelo amor acima de tudo 


\section{AGRADECIMENTOS}

Ao Prof. Dr. Godofredo Cesar Vitti, pelos ensinamentos, amizade e formação profissional;

Aos professores Dr. Álvaro Pires da Silva, Dr. Quirino Augusto de Camargo Carmello e Dr. Takashi Muraoka, pelas críticas e sugestões apresentadas no exame de qualificação;

À Prof ${ }^{\mathrm{a}}$. Dra. Sônia Maria De Stefano Piedade, pela preciosa ajuda nas análises estatísticas;

Ao Conselho do Programa de Pós-Graduação em Solos e Nutrição de Plantas e a CAPES, pela oportunidade e concessão de bolsa de estudos para realização deste curso;

À Mitsui S/A Indústria e Comércio, pelo financiamento do projeto;

À Cargill Agrícola, e seus funcionários, pela concessão da área experimental e apoio na realização do trabalho;

À Universidade Federal de Uberlândia, especialmente ao Prof. Dr. Gaspar Korndörfer, pela ajuda nas análises e troca de experiências;

À grande amiga Mírian Cristina Gomes Costa, pela ajuda nos momentos difíceis e alegria das horas de paz;

Aos colegas Maria Ligia de Souza Silva e Gilmar Ribeiro Nachtigall pelo grande auxílio no momento de urgência;

Ao GAPE, especialmente aos amigos Daniela Ranali e Fernando Reis, pela ajuda na realização do projeto e pela oportunidade da feliz convivência; 


\section{SUMÁRIO}

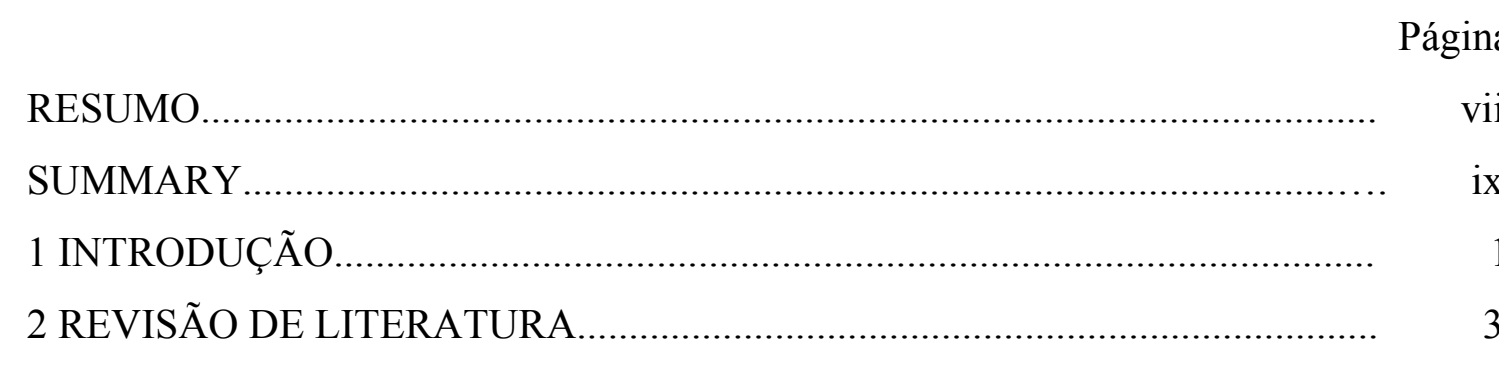

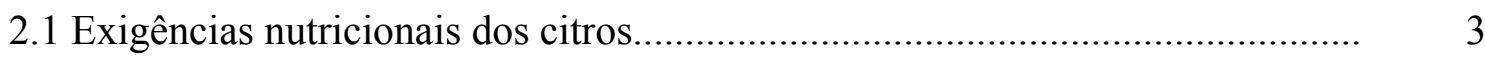

2.1.1 Importância do fósforo nas plantas........................................................... 4

2.1.2 Importância do cálcio nas plantas........................................................ 5

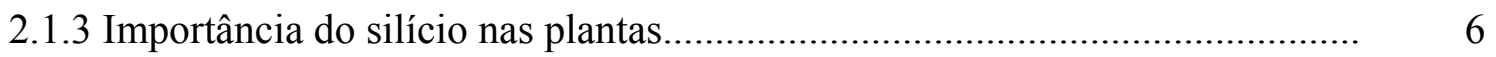

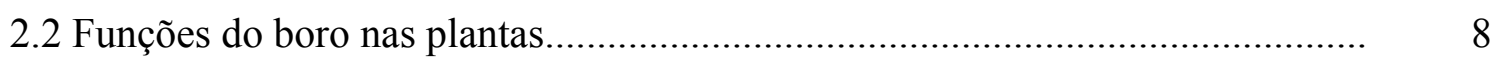

2.3 Sintomas de deficiência, toxidez e níveis foliares de boro na cultura dos citros. 11

2.4 Formas de aplicação do boro: solo X folha........................................................ 13

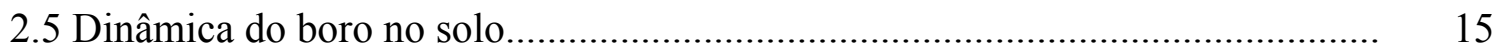

2.6 Teores de boro no solo e recomendações de adubação para a cultura dos citros. 18

2.7 Fontes de boro aplicadas no solo................................................................ 19

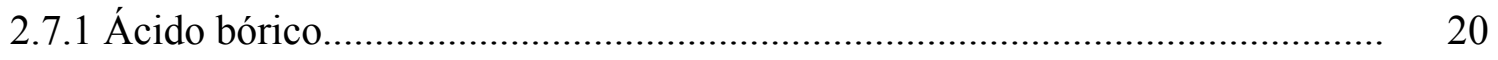

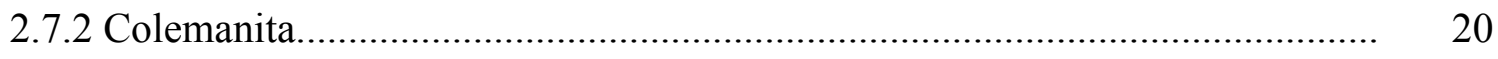

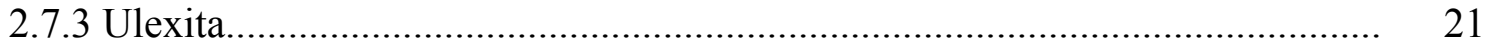

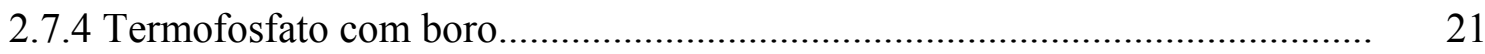

2.8 Eficiência agronômica e efeito residual das fontes de boro.............................. 22

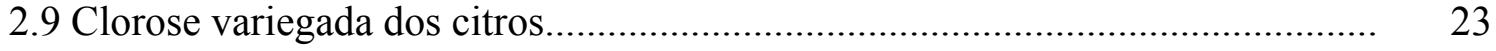

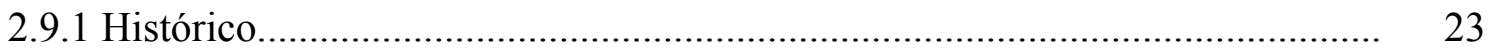

2.9.2 Desenvolvimento da doença e perdas provocadas...................................... 23 


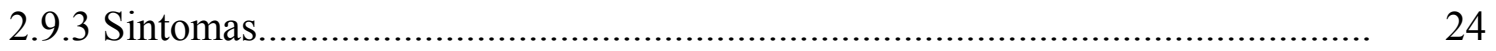

2.9.4 Caracterização, disseminação e modo de ação................................................. 25

2.9.5 Efeitos da doença na produção e qualidade dos frutos..................................... 27

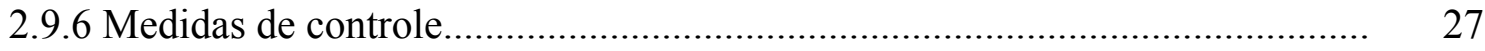

3 MATERIAL E MÉTODOS.................................................................... 29

3.1 Localização da área experimental, variedade, tipo de solo e avaliação do estado nutricional......................................................................................... 29

3.2 Delineamento experimental................................................................. 31

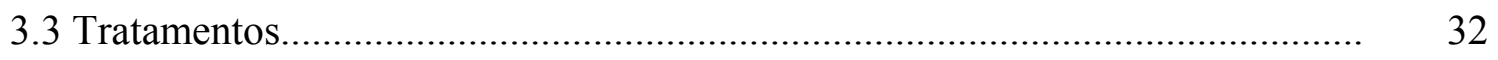

3.4 Calagem, adubações de cobertura e tratos culturais............................................. 34

3.5 Instalação do experimento............................................................................. 34

3.6 Amostragem e análise de folhas............................................................... 35

3.7 Amostragem e análise de solo..................................................................... 35

3.8 Determinação de produtividade e qualidade tecnológica..................................... 36

3.9 Análise estatística................................................................................... 36

4 RESULTADOS E DISCUSSÃO................................................................... 37

4.1 Avaliação do estado nutricional da cultura......................................................... 37

4.2 Avaliação de atributos químicos do solo............................................................ 46

4.3 Avaliação da produtividade dos citros.............................................................. 53

4.4 Avaliação dos atributos qualitativos dos frutos................................................ 55

4.4.1 Atributos tecnológicos dos frutos............................................................... 55

4.4.2 Atributos físicos dos frutos..................................................................... 59

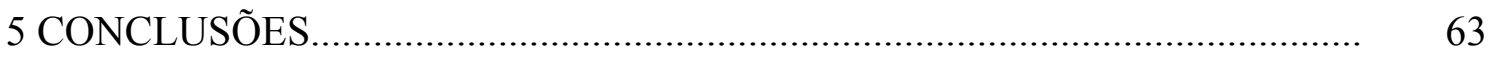

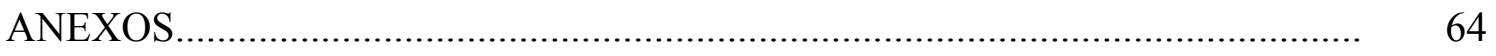

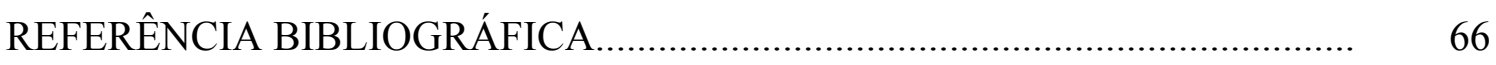




\title{
ADUBAÇÃO BORATADA EM POMAR DE LARANJA PÊRA RIO AFETADO PELA CLOROSE VARIEGADA DOS CITROS
}

\author{
Autora: ISABELA RODRIGUES BOLOGNA \\ Orientador: Prof. Dr. GODOFREDO CESAR VITTI
}

\section{RESUMO}

A cultura dos citros é extremamente dependente de uma nutrição mineral adequada para atingir maiores patamares de produção a menores custos, especialmente sob condições adversas, como no caso da ocorrência da clorose variegada dos citros (CVC). Neste contexto, o boro influencia diretamente a produção por proporcionar maior desenvolvimento radicular, aumentando o volume de solo explorado pelas raízes, maximizando o aproveitamento da água e dos fertilizantes, bem como por estar diretamente envolvido na formação da parede celular, contribuindo para aumento da resistência geral da planta. O presente trabalho foi desenvolvido a partir de um experimento de campo, conduzido no período de setembro de 2001 a agosto de 2002, em área de campo comercial localizada no município de Comendador Gomes (MG). Utilizou-se a variedade Pêra Rio enxertada sobre Limão Cravo no oitavo ano de produção, cultivada em LATOSSOLO VERMELHO-AMARELO Distrófico psamítico. O objetivo do estudo foi avaliar o uso de fontes de boro aplicadas ao solo em diferentes dosagens e sua influência na produção e qualidade do citros afetado pela CVC. Foram avaliados o estado nutricional das plantas, atributos químicos do solo, produtividade, bem como os atributos tecnológicos e físicos dos frutos. As fontes utilizadas foram: ulexita-pó, ulexita-granulada, colemanita-pó, ácido bórico e termofosfato com boro, nas 
dosagens de 1, 2, 3 e $4 \mathrm{~kg} \mathrm{ha}^{-1}$. O delineamento experimental utilizado foi inteiramente casualizado, com fatorial $5 \mathrm{X} 4$, além de dois tratamentos adicionais (testemunha e termofosfato magnesiano), em quatro repetições. A avaliação do estado nutricional foi feita pela análise química dos teores de nutrientes nas folhas amostradas seis meses após a aplicação dos tratamentos. Os atributos químicos do solo foram avaliados por meio de análises das amostras coletadas onze meses após a aplicação dos tratamentos, na profundidade de $0-20 \mathrm{~cm}$. A produção foi avaliada por ocasião da colheita, bem como os atributos tecnológicos e físicos dos frutos. Os resultados mostraram que todas as fontes de boro proporcionaram aumentos significativos nos teores foliares de boro, sendo o ácido bórico e a ulexita-pó as que promoveram os maiores aumentos, não havendo influência das fontes e doses nos teores foliares de $\mathrm{P}, \mathrm{Ca}$ e $\mathrm{Mg}$. Os teores de boro no solo permaneceram acima do nível considerado adequado, sendo observados maiores valores onde utilizou-se fontes menos solúveis como a colemanita e o termofosfato com boro. A produtividade e os atributos físicos dos frutos não tiveram influência da utilização de fontes e doses de boro no pomar com elevada CVC, sendo observado que o aumento da doses de boro aplicado no solo diminuiu a porcentagem de suco no fruto. 


\title{
BORON FERTILIZATION IN PÊRA RIO SWEET ORANGE AFFECTED BY CITRUS VARIEGATED CHLOROSIS
}

\author{
Author: ISABELA RODRIGUES BOLOGNA \\ Adviser: Prof. Dr. GODOFREDO CESAR VITTI
}

\section{SUMMARY}

Citrus crop is extremely dependent on an adequate mineral nutrition to reach bigger levels of production to fewer costs, especially under adverse conditions, as in the case of occurrence of citrus variegated chlorosis (CVC). In this context, boron directly influences the production because it provides a bigger root growth, what increases the volume of the explored soil by the roots, maximizes the use of water and fertilizers, as well as because it is directly involved in the cell wall biosynthesis, what contributes to the increase of the general resistance of the plant. The current study was developed from a field experiment and conducted in the period of September/2001 to August/2002, in a commercial field area located in the city of Comendador Gomes (state of MG). Pêra Rio variety grafted on Limão Cravo was used in the eighth year of production, cultivated in Typic Haplustox. The aim of the study was to evaluate the use of boron sources applied to soil in different dosages and its influence in the production and quality of the citrus affected by CVC. Plant nutritional condition, soil chemical attribute evaluations, productivity, and technical and physical attributes of the fruits were evaluated. The sources used were: ulexite fine, ulexite granular, colemanite fine, boric acid and fused 
boron phosphate, in 1, 2, 3 and $4 \mathrm{~kg} \mathrm{ha}^{-1}$ rates. The experimental design used was completely randomized, with $5 \mathrm{X} 4$ factorial, besides two additional treatments (control and fused magnesium phosphate), in four replications. The evaluation of the nutritional state was done by leaf chemical analysis sampled six months after the application of the treatments. The chemical attributes of the soil were evaluated through analysis of samples collected eleven months after the application of the treatments, at a depth of 0 $20 \mathrm{~cm}$. The production was evaluated on the occasion of the harvest, as well as the technological and physical attributes of the fruits. The results showed that all boron sources promoted significative increases on the leaf boron contents. The higher increase was promoted by boric acid and ulexite fine sources. However didn't happen source and dose influences on leaf contents of $\mathrm{P}, \mathrm{Ca}$ e Mg. The boron soil contents remained higher than the level considerate suitable. The higher soil boron content was observed when sources with low solubility like colemanite and fused boron phosphate were applied. Productivity and fruit physical attributes didn't were influenced by boron sources and dosages in plants with higher incidence of CVC. With the boron doses increase diminish the fruit juice contents. 


\section{INTRODUÇÃ̃O}

O Brasil é atualmente líder absoluto no comércio internacional de suco de laranja concentrado congelado (SLCC) detendo aproximadamente $85 \%$ do volume comercializado internacionalmente. Na produção mundial de laranjas, Brasil e Estados Unidos dividem a posição de liderança, com produções de 18 milhões e 11 milhões de toneladas, respectivamente (FNP, 2003).

Apesar da posição de destaque no cenário mundial citrícola, o país ainda deixa muito a desejar no que diz respeito a produtividade. A média nacional de produção encontra-se entre 2,1 a 2,3 caixas/planta, enquanto que nos Estados Unidos a média chega a 4 caixas/planta.

A expansão da citricultura para regiões marginais de produção, ou seja, para regiões não aptas à produção por apresentarem fatores restritivos, é um dos motivos que explica o baixo desempenho na produção brasileira.

Dentre estes fatores restritivos pode-se citar algumas características que comprometem a produtividade da cultura, entre elas a ocorrência de solos arenosos, distróficos e álicos, com baixa fertilidade natural e baixos teores de matéria-orgânica, suscetibilidade a veranicos, ocorrência de déficit hídrico e temperaturas elevadas. Todos estes fatores, se somados, influenciam a ocorrência e a gravidade de doenças da cultura, especialmente a clorose variegada dos citros (CVC).

A CVC tem afetado consideravelmente a produção, reduzindo a produtividade da cultura e aumentando os custos com defesa fitossanitária, diminuindo assim a lucratividade do setor. As regiões de maior incidência e severidade da doença (Norte do Estado de São Paulo e Sul de Minas Gerais) coincidem justamente com as atuais regiões de expansão da citricultura. 
Dentro deste cenário, a adequada nutrição mineral da cultura é extremamente importante para contribuir para maiores patamares de produção a menores custos. $\mathrm{O}$ estado nutricional da cultura afeta a produtividade de modo direto e também tem efeitos indiretos, proporcionando maior resistência ao déficit hídrico pelo maior desenvolvimento do sistema radicular e maior resistência ao ataque de pragas e doenças.

Neste contexto, o boro assume efeitos diretos, ou seja, o elemento proporciona maior desenvolvimento radicular aumentando assim o volume de solo explorado pelas raízes, maximizando o aproveitamento da água e dos fertilizantes. O elemento também atua diretamente na formação da parede celular, auxiliando a deposição de cálcio nesses tecidos, contribuindo para o aumento da resistência da plantas a efeitos adversos, como por exemplo o ataque de pragas e doenças.

Atualmente tem sido observado crescente preocupação com a adubação boratada na cultura dos citros, com especial atenção para a escolha das fontes e doses mais adequadas que garantam o fornecimento do nutriente durante todo o ciclo da cultura.

Assim, o presente trabalho objetivou estudar o efeito de diversas fontes de boro aplicadas ao solo em diferentes dosagens, na produção e qualidade do citros em produção afetado pela clorose variegada dos citros. 


\section{REVISÃO DE LITERATURA}

\subsection{Exigências nutricionais dos citros}

O citros é uma cultura extremamente exigente em nutrição adequada e equilibrada para atingir maiores patamares de produtividade. Esta alta exigência deve-se ao fato da absorção de elementos pela cultura ocorrer durante todo ano, sendo observados picos de absorção durante o florescimento e durante o crescimento vegetativo, ou seja, durante a formação de folhas e ramos novos (Kampfer \& Uexkull, 1966).

De acordo com Mattos Jr. et al. (2001), para bom desenvolvimento e alta produtividade da cultura há necessidade de atenção para alguns fatores, tais como correta diagnose do estado nutricional e disponibilidade dos nutrientes no solo que garanta seu fornecimento nas quantidades e épocas adequadas.

Dentre os macronutrientes, o cálcio é o elemento que as plantas cítricas contém em mais alta proporção. Os teores totais desse macronutriente superam os de potássio e nitrogênio, que são os nutrientes comumente encontrados em maiores quantidades nas plantas. Devido a esta característica, Rodriguez (1991) cita que as plantas cítricas podem ser chamadas de plantas calcífilas.

De acordo com Kampfer \& Uexkull (1966) pode-se encontrar dentre os macronutrientes a seguinte ordem decrescente de teores foliares nas laranjeiras: $\mathrm{Ca}$ $(4,2 \%)>\mathrm{N}(2,22 \%)>\mathrm{K}(1,31 \%)>\operatorname{Mg}(0,25 \%) \geq \mathrm{S}(0,25 \%)>\mathrm{P}(0,18 \%)$. Para os micronutrientes encontra-se a seguinte ordem decrescente de teores no fruto: $\mathrm{B}>\mathrm{Fe}>$ $\mathrm{Mn}=\mathrm{Zn}>\mathrm{Cu}($ Storey \& Treeby, 2000).

Devido a alta porcentagem de cálcio encontrada na planta cítrica, o 
micronutriente de importância fundamental para a manutenção destes altos valores é o boro. Isto ocorre porque o boro tem relação direta com o metabolismo e incorporação do cálcio na parede celular (Yamauchi et al., 1986). Portanto, o cálcio necessita diretamente do boro para compor as membranas e paredes celulares das plantas. Tendo em vista este aspecto, o correto fornecimento de boro às plantas é extremamente importante para manter os níveis de cálcio nos tecidos.

A expansão da citricultura para regiões marginais de produção, como exemplo regiões antes ocupadas por cerrados nativos como é o caso da região norte do Estado de São Paulo e o sul de Minas Gerais, agrava ainda mais a preocupação na nutrição adequada da cultura. Estas regiões são caracterizadas por solos arenosos, geralmente distróficos e álicos, pobres em matéria orgânica refletindo em baixo aporte de micronutrientes, especialmente o boro.

Encontra-se ainda nestas regiões baixa fertilidade natural, ocorrendo baixos teores de fósforo e cálcio. Tais regiões apresentaram intenso processo de dessilificação, o qual promoveu a retirada do silício do solo (Malavolta \& Kliemann, 1985). Assim, há necessidade de especial atenção na reposição destes nutrientes ao solo por meio das adubações.

Dentre as fontes de boro utilizadas experimentalmente avaliou-se o uso do termofosfato com boro, o qual contém em sua composição, além do boro, fósforo, cálcio e silício, devido esta característica torna-se válido citar a importância destes nutrientes às plantas.

\subsubsection{Importância do fósforo nas plantas}

O fósforo é dentre os macronutrientes primários o exigido em menores quantidades pelas plantas, porém é o mais utilizado em adubações no Brasil. Isto pode ser explicado pela carência generalizada deste elemento nos solos brasileiros e também devido sua forte interação com o solo (Raij, 1991). 
Malavolta \& Violante Netto (1989) citam que o fósforo faz parte de muitos compostos orgânicos, entre eles ésteres de carboidratos, fosfolipídios, coenzimas, núcleo-proteínas e trifosfato de adenosina (ATP).

De acordo com Tibau (1984) o fósforo tem grande importância nos processos de reprodução, multiplicação das células, formação de grãos e sementes e influi diretamente no desenvolvimento e ativação das raízes, o que reflete diretamente na produção das culturas.

As plantas cítricas posuem baixo requerimento de fósforo, para produção de uma tonelada de frutos há exportação de $200 \mathrm{~g}$ de fósforo, portanto para a produção de 40 toneladas de frutos por hectare haverá exportação de $8 \mathrm{~kg}$ de fósforo (Smith, 1966). Porém, Pratt \& Jones (1956) observaram que a cultura dos citros absorve entre 5 a 10 vezes mais fósforo que a quantidade exportada pelos frutos.

Os sintomas de deficiência de fósforo podem ser citados pela perda de brilho ou bronzeamento da folhagem, redução do tamanho das folhas com possível secamento nas pontas e margens, desfolha com aparecimento de galhos desfolhados e redução no crescimento da planta (Smith, 1966).

De acordo com o Grupo Paulista de Adubação e Calagem dos Citros (1994) os teores de fósforo nas folhas de citros geradas na primavera, com 6 meses de idade e de ramos com frutos podem ser classificados de acordo com as seguintes faixas: baixo $\left(<1,2 \mathrm{~g} \mathrm{~kg}^{-1}\right)$, adequado $\left(1,2-1,6 \mathrm{~g} \mathrm{~kg}^{-1}\right)$ e excessivo $\left(>2,0 \mathrm{~g} \mathrm{~kg}^{-1}\right)$.

Bingham et al. (1957) realizando ensaios de adubação de citros com fósforo nas

dosagens de 0 a $1800 \mathrm{~kg} \mathrm{ha}^{-1}$ demonstraram que doses de até $900 \mathrm{~kg} \mathrm{ha}^{-1}$ provocaram maior crescimento das plantas e doses superiores reduziram o crescimento havendo a ocorrência de sintomas de deficiência de cobre, redução na absorção de boro e zinco e aumento na absorção de magnésio e manganês.

\subsubsection{Importância do cálcio nas plantas}

Segundo Epstein (1975), uma das principais funções do cálcio é atuar como agente cimentante, principalmente na forma de pectato de cálcio. O cálcio está 
diretamente relacionado com a atividade meristemática, desempenhando importante papel no desenvolvimento e funcionamento das raízes, multiplicação e crescimento celular.

Malavolta (1987) afirma que o cálcio estimula o desenvolvimento das raízes, aumenta a resistência a pragas e doenças, auxilia na fixação do nitrogênio e aumenta o pegamento da florada.

De acordo com o Grupo Paulista de Adubação e Calagem dos Citros (1994) as faixas adequadas de teores foliares de cálcio, em folhas de 6 meses de idade, geradas na primavera e de ramos com frutos são: baixo $\left(<35 \mathrm{~g} \mathrm{~kg}^{-1}\right)$, adequado $\left(35\right.$ a $\left.45 \mathrm{~g} \mathrm{~kg}^{-1}\right) \mathrm{e}$ excessivo $\left(>50 \mathrm{~g} \mathrm{~kg}^{-1}\right)$.

\subsubsection{Importância do silício nas plantas}

$\mathrm{Na}$ solução do solo a forma predominante de silício é o ácido silícico [ $\left.\mathrm{Si}(\mathrm{OH})_{4}\right]$. O ácido silícico é semelhante ao ácido bórico (ácidos fracos em solução aquosa), os quais possuem a capacidade de interagir com pectinas e fenóis na parede celular dos vegetais, aumentando a resistência dessas estruturas. Ao contrário do boro, a essencialidade do silício para as plantas superiores só foi demonstrada para pequena quantidade de espécies. Porém, o silício é elemento benéfico para muitas espécies e sua omissão em solução nutritiva contribui para ocorrência de estresse ambiental atípico (Marschner, 1995a).

Plantas superiores diferem em sua capacidade de absorver silício, assim, dependendo de seu conteúdo de silício, as plantas podem ser divididas em três grandes grupos: gramíneas de solos inundados, gramíneas de solos secos e algumas dicotiledôneas (Marschner, 1995a).

Segundo Bennett (1982), a silificação da endoderme deve atuar como barreira efetiva contra a invasão de patógenos e parasitas. A deposição preferencial de silício no apoplasma das células epidérmicas e tricomas é refletida nas similaridades entre características da superfície da folha e estruturas de depósitos de silício (Lanning \& Eleuterius, 1989). As paredes das células epidérmicas são impregnadas com uma 
camada firme de silício e torna-se barreira efetiva contra insetos, doenças e até mesmo contra a perda de água pela transpiração cuticular.

Há relatos que o silício aumenta a resistência das plantas contra doenças tanto em monocotiledôneas como em dicotiledôneas. Estudos dos efeitos do silício sobre as doenças das plantas têm envolvido a absorção de silício do solo ou de outros substratos (Menzies et al., 1992).

A aplicação do silício no solo para que o elemento contribua no controle de doenças exige grandes quantidades, principalmente pela ocorrência da interação deste elemento com o solo. Assim, foi necessário aplicar de 250 a $500 \mathrm{~kg} \mathrm{ha}^{-1}$ de silicato de sódio para reduzir a ferrugem do arroz (Mathai et al., 1978). Para reduzir a incidência de um patógeno do pepino foi preciso aplicar de 2000 a $4000 \mathrm{~kg} \mathrm{ha}^{-1}$ de silicato de cálcio ou 2250 a $4500 \mathrm{~kg} \mathrm{ha}^{-1}$ de silicato de potássio (Miyake \& Takahashi, 1983).

De maneira geral, Korndörfer et al. (2002) citam como benefícios do silício nas plantas maior absorção de cálcio e magnésio, redistribuição de manganês nas plantas, maior resistência da parede celular, folhas mais eretas e com maior taxa fotossintética, maior resistência ao ataque de pragas e doenças, mais especificamente insetos sugadores e mastigadores e fungos, redução dos efeitos das geadas, maior regulação da evapotranspiração (menor perda de água) e aumento da produtividade.

O teor de silício nas plantas varia de 1 a $100 \mathrm{~g} \mathrm{~kg}^{-1}$, sendo que na cultura dos citros os teores foliares variam de $0,4 \mathrm{a}_{2 \mathrm{~g} \mathrm{~kg}^{-1}}$ (Matichenkov et al., 1999).

Segundo Whutscher (1989), pouca atenção tem sido dada ao papel do silício na cultura dos citros. Um experimento foi desenvolvido para avaliar os efeitos do silício em plantas de citros de um ano de idade da variedade Hamilin e dois anos da variedade Valência, crescidas durante 7 meses em solução suficiente em silício (66 ppm) e deficiente $(<1 \mathrm{ppm})$. Foi observado que o maior acúmulo de silício ocorre nos tecidos foliares da planta, sendo encontrados os seguintes valores nas variedades Valência e Hamilin, com e sem tratamento com silício: 1,356 e 0,408 $\mathrm{g} \mathrm{kg}^{-1}$ e 1,467 e 0,432 $\mathrm{g} \mathrm{kg}^{-1}$, respectivamente. Foi também encontrada correlação positiva entre o nível de silício e os níveis de fósforo, enxofre, magnésio, ferro, manganês, zinco, cobre e molibdênio. 
Matichenkov et al. (1999) amostraram folhas de plantas cítricas com 1-2 meses de idade e folhas com 1-2 anos e observaram que folhas mais novas apresentaram níveis foliares em torno de 1,3 a 2,8 $\mathrm{g} \mathrm{kg}^{-1}$ e as mais velhas 1,7 a $3,6 \mathrm{~g} \mathrm{~kg}^{-1}$ de silício. Em outro experimento, mudas de grapefruit foram tratadas com soluções de 5, 10 e 20 ppm de $\mathrm{H}_{4} \mathrm{SiO}_{4}$ (ácido monosilícico), sendo observado aumento de peso das raízes de 0,162 $\mathrm{g}$ (controle) para 0,272 g (20ppm).

De acordo com Malavolta et al. (1997) foi observada interação positiva entre o silício e o boro em Brassica napus, pois a adição de silício aumentou a matéria seca da raiz e da parte aérea em níveis baixos de suprimento por boro, sugerindo que o silício estimula a absorção e o transporte de boro nestas condições, com aumento significativo da fotossíntese.

Segundo Korndörfer \& Pereira (2002) o papel do silício nas plantas cítricas ainda tem que ser melhor entendido. Apesar dos poucos estudos, é comum observar que a fertilização com silício pode melhorar a proteção dessas plantas contra efeito de estresse de natureza biótica (ex.: ataque de insetos e infecções) e abiótica (ex.: toxidez provocada por Al, Mn, metais pesados, salinidade e ocorrência geadas e falta de água), potencializando o crescimento e desenvolvimento das plantas.

\subsection{Funções do boro nas plantas}

O boro é um micronutriente que difere dos demais pela não identificação de sua participação na composição de qualquer composto ou enzima específica, sendo sua essencialidade determinada pelo critério indireto (Dechen et al., 1991).

A deficiência em boro causa muitas alterações anatômicas, fisiológicas e bioquímicas nas plantas, porém a maioria destas mudanças provavelmente são decorrentes de efeitos secundários da deficiência (Shelp, 1993).

Apesar do boro não fazer parte de nenhum composto específico, são várias as funções que este elemento desempenha nas plantas. Dentre essas funções, seu papel no crescimento radicular é, sem dúvida, um dos mais importantes. 
O crescimento radicular é resultante dos processos de divisão e elongação celular. De acordo com Shelp (1993), o boro é necessário em ambos processos, e a ocorrência de deficiência inibe o desenvolvimento radicular. Exemplos desta inibição podem ser observados nos trabalhos realizados por Grassi Filho (1991 e 1995).

Grassi Filho (1991) estudando os efeitos de doses de boro (0,065, 0,125, 0,25 e 0,5 ppm), cálcio (50,100, 200 e 400 ppm) e a interação desses dois nutrientes no crescimento radicular do limoeiro Cravo, observou que a dose máxima de boro proporcionou maior comprimento das raízes, não sendo observado interação positiva entre os níveis de cálcio e boro no parâmetro avaliado. Grassi Filho (1995) trabalhando com 3 níveis de boro $\left(0,5,1,5\right.$ e 4,5 $\left.\mathrm{mg} \mathrm{dm}^{-3}\right)$ aplicados em cova de plantio do limoeiro Siciliano enxertado sobre limão Cravo, observou diminuição no peso seco e no comprimento radicular na menor dose de boro testada, sendo que a dose máxima mostrou-se prejudicial ao desenvolvimento da cultura com a ocorrência de queima nas folhas, brotos terminais e pontas dos ramos.

Outra evidência da importância do boro no desenvolvimento radicular foi observada nos trabalhos realizados por Lenoble et al. (1993). Estes autores observaram que os sintomas de toxidez por alumínio e deficiência por boro se apresentam primeiramente como inibição no crescimento radicular. Tendo em vista estes sintomas similares, os autores desenvolveram a hipótese de que a toxidez por alumínio poderia ser agravada pela deficiência de boro. Vários experimentos foram realizados para determinar se altos ou adequados níveis de boro poderiam minimizar os sintomas de toxidez por alumínio, especialmente por meio do incremento no crescimento radicular. Estes experimentos realizados com a cultura da alfafa mostraram que a aplicação de 2,24 $\mathrm{kg} \mathrm{ha}^{-1}$ de boro na forma de ácido bórico "protegeram" as raízes em situações de elevados teores de alumínio, os quais seriam prejudiciais ao seu desenvolvimento. Esta observação tem especial importância para as condições dos solos de regiões tropicais, nos quais comumente encontra-se teores tóxicos de alumínio em profundidade, prejudicando assim o crescimento radicular, especialmente em culturas perenes que exploram maiores profundidades do solo. 
Pode-se encontrar ainda relações do boro na translocação de açúcares, amidos e carboidratos, pois este elemento facilita a translocação destes compostos devido a habilidade de ligar-se aos mesmos, formando complexos que atravessam mais facilmente as membranas celulares do que as moléculas originais, as quais apresentam alto peso molecular (Shelp, 1993).

Outra importante função do boro está relacionada ao metabolismo ou incorporação do cálcio na parede celular (Yamauchi et al., 1986), ou seja, este elemento atua na biossíntese da parede celular auxiliando o cálcio na deposição e formação de pectatos envolvidos na construção destas estruturas. A deficiência em boro altera a estrutura e a organização celular das membranas e exemplo desta desestruturação pode ser observado em trabalho desenvolvido por Cakmak et al. (1995). Estes autores compararam folhas de girassol deficientes em boro com folhas de teores normais, observando extravasamento de potássio, sacarose e aminoácidos nos valores respectivamente de 35, 45 e 7 vezes maiores para folhas deficientes.

Além disso, uma das conseqüências da deficiência de boro é o aumento na concentração do ácido endol acético (IAA), pois a atividade da IAA oxidase é inibida, resultando em acúmulo de compostos fenólicos nas regiões de crescimento das plantas, mais notadamente raízes e gemas terminais (Graham \& Webb, 1991).

Efeitos diretos do elemento na produção das culturas são atribuídos ao fato do boro desempenhar função no crescimento do tubo polínico e na germinação do grão de pólen, explicando a maior demanda deste nutriente na fase de formação das sementes em relação a fase de crescimento vegetativo (Marschner, 1995a). Mengel \& Kirkby (1982) citam que plantas inadequadamente supridas por boro apresentam distúrbios na germinação do tubo polínico prejudicando a formação dos frutos.

Agarwala et al. (1981) testaram vários níveis de boro na cultura do milho e observaram que plantas cultivadas em baixos níveis de boro $(0,066 \mathrm{ppm})$ desenvolveram pouca germinação do grão de pólen, mesmo não sendo observado sintomas foliares da deficiência deste nutriente. Os mesmos autores concluíram que o baixo desenvolvimento de pólen em plantas deficientes em boro demonstra a relação do nutriente no 
desenvolvimento reprodutivo, afetando a formação de gametas funcionais, ou seja, prejudicando a viabilidade do grão de pólen.

O boro também afeta a quantidade e a composição dos açúcares do néctar das flores tornando-as mais atrativas à polinização por insetos (Ericksson'; citado por Marschner, 1995a).

$\mathrm{Na}$ cultura dos citros, Vitti (1992) cita que os principais efeitos do boro estão relacionados ao tamanho e a qualidade do fruto, pois este elemento atua diretamente no funcionamento e formação da parede celular, germinação do grão de pólen, crescimento do tubo polínico e transporte de carboidratos.

\subsection{Sintomas de deficiência, toxidez e níveis foliares de boro na cultura dos citros}

O teor total de boro nas plantas sofre variação de acordo com a espécie estudada e com o tipo de solo onde esta é cultivada. De modo geral, espécies dicotiledôneas exigem maiores quantidades do nutriente do que as monocotiledôneas.

Malavolta \& Kliemann (1985) citam que as principais causas para a ocorrência da deficiência por boro são os baixo teores totais no solo; solos formados a partir de rochas ígneas ácidas ou rochas sedimentares; solos lixiviados, ácidos, neutros ou alcalinos; baixos teores de matéria-orgânica; uso excessivo de adubos nitrogenados e calagem excessiva ou mal feita.

Devido a imobilidade e ausência de redistribuição deste nutriente, os sintomas de deficiência na planta aparecem primeiramente nas folhas novas e nas regiões terminais, como raízes e meristemas.

De acordo com Smith (1966) os sintomas de deficiência em boro podem ser caracterizados como vegetação nova de cor verde sem brilho, rala e com algumas folhas deformadas apresentando, às vezes, cortiça nas nervuras; frutos com muito albedo e goma próxima da pele, podendo ocorrer também nos lóculos; queda excessiva de frutos

\footnotetext{
${ }^{1}$ ERICKSSON, M. The effect of boron on nectar production and seed setting of red clover. Sweden Journal of Agricultural Research, n.9, p.37-41. 1979.
} 
novos e sementes abortadas. Pode ocorrer também colapso interno do floema, acarretando vários sintomas indiretos decorrentes deste acinturamento.

Bradford (1966) classifica os teores de boro nas folhas do ciclo primaveril com idade entre 4 a 10 meses como: deficiente quando menor que $15-20 \mathrm{mg} \mathrm{kg}^{-1}$, baixo entre 15-40 mg kg-1, satisfatório entre 50-200 mg kg-1, alto entre $200-250 \mathrm{mg} \mathrm{kg}^{-1}$ e excessivo quando superior a $250 \mathrm{mg} \mathrm{kg}^{-1}$.

Malavolta \& Violante Netto (1989) citam como sintomas de toxidez de boro em citros amarelecimento das folhas nas pontas e margens e em seguida entre as nervuras, refletindo aspecto de clorose malhada; desenvolvimento de pontuações ou pequenas áreas necróticas no limbo ou na margem; queda de folhas, e em casos severos, os autores relatam diminuição do tamanho das mesmas e, no lançamento seguinte, as folhas podem ser brancas, exceto ao longo das nervuras, onde continua de coloração verde.

$\mathrm{Na}$ cultura dos citros, níveis de boro maiores que 50 a $100 \mathrm{mg} \mathrm{kg}^{-1}$ podem causar sintomas de toxidez nas folhas e, em casos mais severos, acarretam redução na produção. Porém, de acordo com Smith (1954), não foram encontradas quedas nas produções de laranjeiras com níveis foliares maiores que $392 \mathrm{mg} \mathrm{kg}^{-1}$. A redução na produção foi apenas observada quando níveis foliares chegaram a $940 \mathrm{mg} \mathrm{kg}^{-1}$ sendo que, no ano seguinte, o nível foliar de boro reduziu para $279 \mathrm{mg} \mathrm{kg}^{-1}$, não observando-se mais a redução na produção.

Segundo Del Rivero (1964) a absorção de boro pelos citros provoca diminuição no teor de fósforo das folhas e favorece a relação $\mathrm{K}: \mathrm{Ca}$, aumentando o conteúdo de potássio e diminuindo o de cálcio. O mesmo autor cita que o excesso de boro pode causar desfolha prematura, queda no vigor geral da planta cítrica, diminuição nos teores foliares de manganês e nos teores de vitamina $\mathrm{C}$ e ácido cítrico dos frutos.

Devido a estreita faixa entre a suficiência e a toxidez deste elemento pode-se comumente encontrar sintomas de excesso de boro decorrentes do seu uso excessivo ou mal direcionado.

De acordo com Mattos Jr. et al. (2001) tem sido observado, em condições de campo, toxidez por boro em pomares cítricos recém implantados quando utilizada a dosagem de $2 \mathrm{~kg} \mathrm{ha}^{-1}$ com aplicação localizada ao redor das mudas, sendo esta 
concentração a razão principal para o aparecimento dos sintomas de toxidez e, em muitos casos, para a morte das plantas.

Outro aspecto importante a ser observado é a relação $\mathrm{Ca}: \mathrm{B}$ no tecido vegetal, pois esta relação pode ser considerada como indicadora do estado nutricional para o boro. Elevadas relações $\mathrm{Ca}: \mathrm{B}$ indicam deficiência em $\mathrm{B}$ devido provavelmente a altas concentrações de cálcio nos tecidos foliares (Gupta, 1993).

Relações Ca:B maiores que 1370 na cultura da cevada (Gupta, 1972) e 3300 em nabo (Gupta \& Cutcliffe, 1972) indicam deficiência em boro. O aumento no nível de boro nas plantas provoca reduções nas relações $\mathrm{Ca}: \mathrm{B}$.

Sintomas visuais de deficiência de boro são acentuados pela deficiência de cálcio, sendo menos evidente quando o cálcio encontra-se em excesso (Chatterjie et al., 1987).

Porém, a observação isolada da concentração total destes dois nutrientes é muito importante, bem como a deficiência ou toxidez de um ou ambos pode dar falsa relação da condição nutricional da planta. Assim, Gupta (1993) sugere que a observação da relação $\mathrm{Ca}: \mathrm{B}$ não pode ter a mesma importância do que o teor dos elementos quando analisados individualmente.

\subsection{Formas de aplicação de boro: solo $X$ folha}

Existem duas maneiras de fornecer o elemento boro às culturas, uma é sua aplicação direta no solo e a outra é o fornecimento por meio de pulverizações foliares.

A aplicação direta no solo poder ser feita pelo uso de adubos boratados simples ou com o uso de adubos mistos que contenham boro em sua formulação, aplicando-se em área total ou concentrando a aplicação em faixas de adubação.

A aplicação de micronutrientes conjunta aos fertilizantes N-P-K resulta em maior uniformidade na distribuição, devido ao fato de que a quantidade de micronutriente a ser aplicada é muito menor se comparada às utilizadas nas adubações N-P-K. Isto torna-se especialmente importante no caso da adubação boratada, pois o limite entre a suficiência 
e a toxicidade é muito estreito e a obtenção de homogeneidade na aplicação é desejável. Outra vantagem é a redução nos custos com a aplicação conjunta dos fertilizantes.

Estudos realizados por Gupta \& Cutcliffe (1978) mostraram que a aplicação localizada de boro na dosagem de $1,12 \mathrm{~kg} \mathrm{ha}^{-1}$ resultou em maiores níveis foliares deste elemento na cultura do trevo em relação a aplicação de $2,24 \mathrm{~kg} \mathrm{ha}^{-1}$ em área total. Isto pode ser explicado pelo fato de que a aplicação localizada direciona a maior concentração do elemento na zona radicular, ou seja, promove maior concentração do elemento em uma pequena área, proporcionando rápida absorção pelas plantas.

A aplicação foliar, de modo geral, resulta em menores níveis foliares do elemento do que a aplicação no solo. Isto é explicado pelo fato do boro possuir pouca mobilidade no floema, sendo ausente a redistribuição para diferentes partes da planta, ou seja, o elemento não possui a característica de se deslocar de partes velhas da planta para regiões de crescimento (partes novas) e consequentemente de maior demanda. Exceções de mobilidade são feitas às plantas que produzem polióis; que são compostos com característica de complexar o boro tornando-o móvel no floema, como é o caso das amendoeiras, macieiras e nectarinas (Yamada, 2000).

Exemplo da imobilidade do elemento foi observado no estudo de Martini \& Thellier (1980), onde mais de 98\% do boro aplicado foliarmente na cultura do trevo branco permaneceu no mesmo local de aplicação e apenas $2 \%$ do total aplicado foi utilizado para o crescimento de outras partes da planta.

Conforme mostrado por Gupta (1993), em experimento realizado com a cultura da cevada, a aplicação no solo de $2 \mathrm{~kg} \mathrm{ha}^{-1}$ de boro resultou em maiores teores foliares deste elemento $\left(11,9 \mathrm{mg} \mathrm{kg}^{-1}\right)$ do que a aplicação da mesma quantidade fornecida em pulverizações foliares $\left(7,7 \mathrm{mg} \mathrm{kg}^{-1}\right)$, indicando a maior eficiência das raízes em absorver boro quando comparada às folhas.

Porém, de acordo com Foroughi et al. ${ }^{2}$ citados por Mengel \& Kirkby (1982), tanto a aplicação no solo de 50 a $200 \mathrm{~g}$ de boro por planta, quanto a pulverização foliar de 15 a $60 \mathrm{mg}$ de boro por planta foram efetivas na correção dos sintomas de deficiência

${ }^{2}$ FOROUGHI, M.; MARSCHNER, H.; DÖRING, H.W. Occurrence of boron deficiency in Citrus aurantium L. (bitter orange) at the Caspian Sea (Iran). Z. Pflanzenernähr Bodenk, n.136, p.220$228,1973$. 
de boro na cultura da laranja, sendo que a correção da deficiência promoveu aumento considerável na qualidade da fruta.

Segundo Malavolta \& Kliemann (1985), em virtude da dificuldade de translocação do boro no floema, sua aplicação no solo é muito mais eficiente, pois além de elevar rapidamente o seu teor na folha possui também efeito mais duradouro em relação à aplicação foliar feita por contínuas pulverizações.

De acordo com Mattos Jr. et al. (2001), a aplicação de boro via solo em plantas cítricas que apresentam sintomas de deficiência, reativa o sistema de condução da seiva para as raízes que crescem rapidamente, provocando brotações exuberantes na parte aérea, com formação de ramos longos e folhas maiores do que as deficientes.

Barnard et al. (1973) testaram em laranja Washington Navel o uso de boro no solo e em pulverizações foliares e observaram que o teor nas folhas foi significativamente maior quando o elemento foi aplicado na forma de bórax no solo e não nas folhas.

Cabrita (1993) estudando o efeito das aplicações de boro no solo na forma de óxidos silicatados e foliarmente na forma de ácido bórico, durante três anos consecutivos em pomares em início de produção (5 anos) e em plena produção (16 anos), observou que o boro teve seus níveis foliares aumentados principalmente pela aplicação no solo evidenciando ser esta a melhor forma de elevar os teores deste nutriente nas folhas.

De modo geral, a aplicação foliar poderá ser mais vantajosa em condições específicas, tais como na ocorrência de sintomas visuais de deficiência do elemento, a qual necessita de rápida correção, em casos onde o boro foi excluído da adubação no solo ou ainda como uma complementação da adubação de boro no solo.

\subsection{Dinâmica do boro no solo}

São vários os fatores relacionados ao solo que influenciam a disponibilidade do boro na solução do solo e, conseqüentemente, sua absorção pelas plantas. Dentre estes fatores tem-se o $\mathrm{pH}$ como um dos mais importantes. 
A espécie de boro predominante na solução do solo entre pH 5 a 9 é a molécula não ionizada $\mathrm{H}_{3} \mathrm{BO}_{3}{ }^{0}$, sua natureza não iônica faz com que este elemento torne-se altamente móvel no solo e, conseqüentemente, muito lixiviado nestas condições de $\mathrm{pH}$. A valores de $\mathrm{pH}$ maiores que 9,2 ocorre a hidrolização do boro que passa de $\mathrm{H}_{2} \mathrm{BO}_{3}{ }^{-}$a $\mathrm{H}_{4} \mathrm{BO}_{4}^{-}$(Tisdale et al., 1985). Moraghan \& Mascagni (1991) também citam que o boro está presente no solo na forma de $\mathrm{H}_{3} \mathrm{BO}_{3}{ }^{0}$ a $\mathrm{pH}$ abaixo de 7 , sendo esta forma não adsorvida pela fração coloidal do solo; aumentos de $\mathrm{pH}$ acima deste valor incrementam a concentração da forma $\mathrm{H}_{4} \mathrm{BO}_{4}{ }^{-}$, proporcionando queda na atividade do elemento na solução do solo devido a adsorção desta forma de boro às superfícies dos minerais de argila e hidróxidos de alumínio.

Pavan e Correa (1988) avaliando a adsorção do boro em solos do Estado do Paraná observaram que a maior taxa de adsorção foi encontrada no intervalo de $\mathrm{pH}$ entre 6,5 e 8,0, resultado explicado pelo aumento do número de sítios ativos de adsorção e pela maior proporção do íon borato $\left(\mathrm{H}_{4} \mathrm{BO}_{4}{ }^{-}\right)$em relação ao ácido bórico molecular $\left(\mathrm{H}_{3} \mathrm{BO}_{3}{ }^{0}\right)$. Estes autores citam ainda que a reacidificação dos solos provocou aumento nos teores de boro solúvel, indicando que a adsorção de boro por solos altamente intemperizados, submetidos a calagem para elevação do $\mathrm{pH}$ a valores entre 6,0-6,5, é caracterizada por uma reação química rápida e reversível entre o boro adsorvido e o boro solúvel, sugerindo que a calagem causa deficiência de boro apenas em solos com teores iniciais próximos do limite de deficiência.

A textura do solo é um fator que também afeta a disponibilidade de boro, principalmente pelo fato de que parte do boro do solo encontra-se adsorvido por partículas de argila com maior ou menor energia de adsorção.

Biggar \& Fireman (1960) e Singh (1964) observaram maior capacidade de retenção de boro em solos de textura mais fina quando comparado aos de textura arenosa.

Gupta (1968) trabalhando com dois tipos de solos, arenoso e argiloso, observou que os teores de boro total e solúvel em água quente foram maiores em solos de textura mais fina, havendo menor recuperação do boro adicionado ao solo arenoso. 
Segundo Mortvedt (1994) a maioria dos solos apresentam, até certa forma, limitação na mobilidade do boro, porém em solos arenosos sob condições de elevada precipitação ou irrigação este elemento pode ser altamente lixiviado.

Page \& Cooper ${ }^{3}$ citados por Gupta (1993) demonstraram que as perdas por lixiviação em solos arenosos chegaram a $85 \%$ do total do boro aplicado após a adição de 12,5 cm de água, situação explicada pelo baixo poder de fixação do elemento neste tipo de solo e, conseqüentemente, maior movimentação e lixiviação do boro.

Correa et al. (1985) estudaram a resposta de mudas de café à aplicação de boro em dois tipos de solos, um Latossolo Roxo distrófico com 75\% de argila e um Latossolo Vermelho-Escuro distrófico com 11\% de argila, observando que o Latossolo com maior porcentagem de argila adsorveu 4,25 $\mathrm{mg} \mathrm{kg}^{-1}$ de boro, o correspondente a $8,5 \mathrm{~kg}$ de boro por hectare, na camada de 0-20 $\mathrm{cm}$ para a maior produção de matéria-seca $(23,6 \mathrm{~g} / \mathrm{planta})$. Já o solo com $11 \%$ de argila adsorveu cerca de $2,05 \mathrm{mg} \mathrm{kg}^{-1}$ de boro $(4,1$ $\mathrm{kg}$ de boro por hectare) com produção de 21,5g/planta, porém com maiores níveis foliares de boro. Estes valores de adsorção (8,5 e 4,1 kg de B por hectare) contrastam com a recomendação oficial da Comissão de Fertilidade do Solo do Estado de Minas Gerais (1999) para a cultura do café, a qual é de $3 \mathrm{~kg} \mathrm{ha}^{-1}$.

Outro fator a ser considerado é que o boro movimenta-se no solo através dos processos de difusão e fluxo de massa e a falta de água no solo dificulta o processo de movimentação do elemento até a superfície radicular. Segundo Dantas (1991) outras hipóteses são levantadas para explicar o fato da diminuição no teor de água do solo afetar a disponibilidade de boro no solo, tais como diminuição na taxa de mineralização da matéria-orgânica; diminuição no teor de boro prontamente disponível às plantas; redução no crescimento radicular, gerando menor exploração de solo pelas raízes e, conseqüentemente, menor absorção de boro pela planta.

Em relação a presença de outros nutrientes no solo afetando a disponibilidade do boro, Tisdale et al. (1985) observaram que quando há elevada disponibilidade do cálcio no solo a exigência de boro pelas culturas é maior. Assim, em condições de deficiência

\footnotetext{
${ }^{3}$ PAGE, N.R.; COOPER, H.P. Less-soluble boron compounds for correcting boron nutricional deficiencies. Journal of Agricultural Food Chemicals, n.3, p.222-231, 1955.
} 
de cálcio no solo, as plantas apresentaram baixa tolerância e conseqüente toxidez por boro.

Bingham et al. (1957) estudaram o efeito da adubação fosfatada, em 4 dosagens $(85,2,404,1010$ e $2020 \mathrm{~kg}$ de fósforo por hectare), na absorção de boro por mudas de citros em 9 tipos de solos diferentes, observaram que com o aumento da aplicação de $\mathrm{Ca}\left(\mathrm{H}_{2} \mathrm{PO}_{4}\right)_{2}$ houve redução nos teores de boro foliar, em média de $40 \%$. A explicação encontrada pelos autores para tais resultados é a de que a adição de cálcio por meio da fonte fosfatada contribuiu para a formação de boratos de cálcio de menor solubilidade e também que os ânios de fosfato competem com o borato pela absorção das plantas.

O contrário foi encontrado por Tanaka ${ }^{4}$ citado por Gupta (1993). Trabalhando com rabanete, o autor observou que a absorção de boro pela cultura aumentou com o acréscimo do fornecimento de fósforo. A interação positiva entre estes dois nutrientes foi observada por Wojeik (1999) trabalhando com a cultura da maçã, onde a aplicação de boro no solo aumentou a absorção de fósforo, o que pode ser comprovado por meio do aumento na concentração de fósforo foliar.

\subsection{Teores de boro no solo e recomendação de adubação para a cultura dos citros}

De acordo com o Grupo Paulista de Adubação e Calagem para Citros (GPACC) (1994), os valores de boro no solo para a cultura dos citros podem ser classificados da seguinte forma: baixo $\left(<0,20 \mathrm{mg} \mathrm{dm}^{-3}\right)$, médio $\left(0,20\right.$ a $\left.0,60 \mathrm{mg} \mathrm{dm}^{-3}\right)$ e alto $(>0,60 \mathrm{mg}$ $\left.\mathrm{dm}^{-3}\right)$.

Devido ao estreito limite entre deficiência e toxidez, Mortvedt (1994) recomenda a aplicação de 0,2 a 3,0 kg de boro por hectare, com especial atenção à uniformidade na aplicação do adubo em condições de campo, para que se evite a concentração do elemento em uma mesma área.

\footnotetext{
${ }^{4}$ TANAKA, H. Boron adsorption by crop plants as affected by other nutrients of the medium. Soil Science and Plant Nutrition, v.13, n.41, p.233-241, 1967.
} 
Para a cultura dos citros, as recomendações de boro devem tomar por base a análise de solo para o nutriente, porém é recomendado o uso de dose máxima de $2 \mathrm{~kg}$ de boro por hectare.

Segundo o GPACC (1994), a recomendação da adubação boratada é indicada para solos que apresentam níveis deficientes de boro (abaixo de 0,2 $\mathrm{mg} \mathrm{dm}^{-3}$ ). A dose indicada para pomares em produção é de $1,5 \mathrm{~kg} \mathrm{ha}^{-1}$, sendo também recomendado ao menos uma aplicação foliar deste elemento, preferencialmente na época de florescimento, logo após a queda das pétalas, com a pulverização de solução à concentração de $0,1 \%$ de boro.

Observa-se que as recomendações oficiais para a cultura não consideram alguns fatores importantes que afetam a disponibilidade do elemento, tais como o tipo de solo, variedade e população de plantas na área cultivada, o que pode refletir em certas ocasiões, em adubações com dosagens menores do que a necessária.

\subsection{Fontes de boro aplicadas no solo}

A escolha da melhor fonte de boro para aplicação no solo depende do tipo de solo, da cultura e do regime hídrico. A maioria dos adubos boratados apresentam alta solubilidade, estando sujeitos a maior mobilidade no solo e, conseqüentemente, maior grau de lixiviação, principalmente em solos arenosos. Devido a estes fatores têm sido observado uso crescente de fontes com solubilidade lenta, portanto menos suscetíveis a perdas por lixiviação (Mortvedt, 1994).

Segundo Hortenstine et al. (1958), o uso de fontes de boro de alta solubilidade apresenta algumas desvantagens, como exemplo a alta disponibilidade inicial, podendo

gerar sintomas de toxidez em plantas mais sensíveis ao elemento; alto potencial de lixiviação, principalmente em solos arenosos e irregular disponibilização do elemento durante o crescimento da cultura.

Estes fatores tornam-se especialmente importantes às culturas perenes instaladas em solos arenosos, as quais necessitam do uso de fontes que garantam o fornecimento 
adequado e abaixo do nível de toxidez do nutriente durante todo o ciclo e que sejam resistentes a perdas excessivas por lixiviação.

Existem várias fontes de boro usadas em aplicações via solo, algumas delas estão descritas a seguir.

\subsection{1 Ácido bórico}

Apresenta-se na forma de cristais de ácido bórico $\left(\mathrm{H}_{3} \mathrm{BO}_{3}\right)$, com teor de boro na faixa de 17-18\%. Devido sua alta solubilidade em água e baixa reatividade com o solo, esta fonte é extremamente suscetível a lixiviação, principalmente em solos arenosos e em locais sujeitos a elevada precipitação (Byers et al., 2001). A alta disponibilidade inicial pode provocar sintomas de toxidez em culturas susceptíveis e em estágios iniciais de desenvolvimento.

\subsubsection{Colemanita}

Caracteriza-se por ser um borato de cálcio $\left(\mathrm{Ca}_{2} \mathrm{~B}_{6} \mathrm{O}_{11} .5 \mathrm{H}_{2} \mathrm{O}\right)$, de ocorrência na natureza, muitas vezes associada a ulexita, podendo até mesmo ser resultante de sua alteração. Seu teor em boro é variável de 10-16\%, de acordo com seu grau de hidratação. Serve como matéria-prima para fabricação de outros adubos boratados mais solúveis (ex.: bórax). Possue ainda 15-20\% de cálcio.

Apresenta moderada solubilidade, que pode ser aumentada dependendo de sua granulometria. Foi uma das primeiras fontes de boro avaliada como sendo de lenta liberação.

A colemanita é usada com maior freqüência em solos arenosos, pois é considerada a fonte de boro menos solúvel e portanto menos sujeita a lixiviações neste tipo de solo (Murphy \& Walsh, 1972). 


\subsubsection{Ulexita}

É um borato de sódio e cálcio $\left(\mathrm{NaCaB}_{5} \mathrm{O}_{2} .8 \mathrm{H}_{2} \mathrm{O}\right)$. Dentre os boratos de cálcio é o mais solúvel, liberando boro mais lentamente de acordo com sua granulometria. Sua solubilidade depende diretamente da proporção entre $\mathrm{Na}$ e $\mathrm{Ca}$ presentes no mineral (Byers et al., 2001). O teor de boro varia de 10-15\% e o de cálcio está em torno de 12$14 \%$.

Pode-se encontrar no mercado a ulexita na forma granulada obtida por meio do processo de granulação com a utilização de ácido sulfúrico, o qual proporciona aumento na solubilidade, em torno de $90 \%$ de solubilidade em água, apresentando ainda um teor residual de enxofre por volta de $4 \%$.

\subsubsection{Termofosfato com boro}

Os termofosfatos são definidos como fertilizantes resultantes do tratamento térmico de rochas fosfatadas com ou sem adição de outros materiais. O tratamento térmico visa converter o fósforo em formas mais disponíveis, ou seja mais solúveis. $\mathrm{O}$ fosfato natural, enriquecido com silicato de magnésio é derretido em forno elétrico à temperatura de $1500^{\circ} \mathrm{C}$, tornando-se um produto incandescente que é submetido a choque térmico com jato de água, sendo posteriormente seco e moído (Souza \& Yasuda, 1995).

Possui a característica de não ser higroscópico e ser insolúvel em água, porém totalmente solúvel em ácido cítrico. A fonte de boro comumente adicionada neste processo de fabricação é a colemanita, sendo que o tratamento térmico proporciona aumento em sua solubilidade natural. Sua composição obedece as seguintes garantias: $17 \% \mathrm{P}_{2} \mathrm{O}_{5}$ total, $20 \% \mathrm{Ca}, 7 \% \mathrm{Mg}, 0,4 \% \mathrm{~B}$ e $23 \% \mathrm{SiO}_{2}$. 


\subsection{Eficiência agronômica e efeito residual das fontes de boro}

Vários autores citam que a escolha da fonte de boro depende da cultura e do sistema de plantio. Hunter et al. (1990) sugerem o uso da ulexita ou colemanita granuladas como sendo as melhores fontes para culturas perenes, como o caso do pinus. Byers et al. (2001) indicam a colemanita como a fonte mais eficiente no fornecimento de boro quando comparada às fontes sódio-boratadas mais solúveis para a cultura do algodão instalado em solos arenosos mais sujeitos a lixiviação. Segundo estes autores é recomendado o uso de fontes de alta solubilidade no momento do plantio, sendo que a manutenção dos teores de boro durante o desenvolvimento da cultura anual deverá ser feita com o uso de fontes menos solúveis; já para culturas perenes recomenda-se fontes de liberação lenta, como o caso dos boratos de cálcio granulados.

Lavín (1988) conduziu experimento para avaliar o grau de toxidez da aplicação por 2 anos consecutivos de 25 g ulexita por planta em várias espécies frutíferas sob irrigação por gotejamento. Foi observado grande diferença na suscetibilidade das culturas ao excesso de boro. As culturas de framboesa, caqui, pistache e nogueira foram as que apresentaram maiores sintomas de toxidez, com níveis foliares de boro em torno de $841,1030,699$ e $900 \mathrm{mg} \mathrm{kg}^{-1}$, respectivamente. Os sintomas de toxidez não foram observados nas culturas do damasco, pêra, nectarina e maçã. A remissão dos sintomas de toxidez foram conseguidas por meio do uso de irrigação por inundação repetidas vezes, com o intuito de lixiviar o boro presente na zona radicular. Dois anos após a última aplicação, a maior parte das árvores haviam se recuperado dos danos causados pelo excesso de boro, sendo que algumas cresceram com maior velocidade que a observada antes da aplicação do mesmo.

O efeito residual do adubo boratado no solo depende do tipo do solo e da forma de boro aplicada. O maior efeito residual é observado em solos com altos teores de silte e argila quando comparado com solos arenosos. Fontes de boro de baixa solubilidade também proporcionam maior efeito residual.

Hunter at al. (1990) testaram o uso de diferentes formas de boro (borato de sódio, colemanita pó e granulada e ulexita pó e granulada) na dosagem de $6 \mathrm{~kg}$ por hectare de 
boro e suas influências nos teores foliares de boro na cultura do pinus durante 4 anos consecutivos. Os autores observaram que as fontes que proporcionaram melhores efeito residual ao longo dos anos foram a colemanita e ulexita granulada, garantindo teores foliares de boro adequados durante os 4 anos observados. Já o uso do borato de sódio, por ser uma fonte extremamente solúvel, provocou sintomas de excesso de boro logo no primeiro ano de aplicação, com níveis foliares maiores que $80 \mathrm{mg} \mathrm{kg}^{-1}$.

\subsection{Clorose variegada dos citros (CVC)}

\subsubsection{Histórico}

A clorose variegada dos citros (CVC), também conhecida pelo nome de amarelinho dos citros é uma doença causada pela bactéria Xylella fastidiosa transmitida pelo inseto vetor cigarrinha (Hemiptera: Cicadellidae) que foi observada pela primeira vez no Brasil no ano de 1987 no município de Colina/SP e logo depois no Triângulo Mineiro e nas regiões norte e noroeste do Estado de São Paulo (De Negri, 1990).

Desde a sua primeira constatação até a certeza de que a doença era causada por uma bactéria, muitas hipóteses para sua ocorrência foram levantadas, dentre elas citamse: provável causa virótica, desequilíbrio nutricional (Vitti et al., 1989; Malavolta et al., 1992; Malavolta \& Prates, 1991) e sintomas de toxidez provocada pelo uso excessivo de herbicidas (Castro, 1992). Porém, em 1989 houve a confirmação, por meio de estudos de microscopia eletrônica, de que fora encontrada a bactéria Xylella fastidiosa colonizando os vasos do xilema de tecidos sintomáticos (Rossetti \& De Negri, 1990). A partir de então ficou provado que todas as outras possíveis causas para a ocorrência da doença eram na verdade conseqüência da mesma.

\subsubsection{Desenvolvimento da doença e perdas provocadas}

Desde a primeira constatação da doença em 1987 surgiu a necessidade de se quantificar seu grau de incidência. De acordo com Malavolta \& Prates (1991) foram 
realizados levantamentos da porcentagem de incidência da doença nas regiões Norte e Noroeste do Estado de São Paulo e no Sul do Estado de Minas Gerais, nos anos de 1989 e 1990 onde constatou-se que $2,23 \%$ dos pomares visitados apresentaram os sintomas da CVC. Os sintomas encontrados eram mais expressivos em plantas com idade entre 2 a 8 anos. Segundo os mesmos autores, novos levantamentos foram realizados nas mesmas regiões, entre os anos de 1990 e 1991, sendo observado crescimento no grau de incidência para 2,83\%, com maior expressividade em plantas entre 2 a 6 anos de idade.

De acordo com Laranjeira (1997), após 10 anos da primeira constatação da clorose variegada dos citros em pomares do Estado de São Paulo, foi observado que 23 a $25 \%$ dos pomares paulistas já apresentavam sintomas foliares da doença.

No último levantamento realizado pelo Fundecitrus (2003), 36,44\% dos pomares do Estado de São Paulo e do Triângulo Mineiro apresentaram sintomas da doença, sendo que $24,07 \%$ destes sintomas enquadram-se no grau de severidade 2 (plantas com sintomas foliares e frutos miúdos). A região mais afetada é o Norte do Estado de São Paulo (região de Barretos e Bebedouro) e a idade da planta em que é observada a maior porcentagem de incidência da doença é entre os 6 a 10 anos.

Gonçalves (2002) estimou que as perdas provocadas pela doença no ano de 2000 foram de aproximadamente 650 milhões de reais.

\subsubsection{Sintomas}

Os sintomas da clorose variegada dos citros se manifestam nas folhas, ramos e frutos das plantas atacadas. Nas folhas são observadas manchas cloróticas internervais na parte superior, com desenvolvimento de pequenas bolhas de coloração vermelhomarrom correspondendo ao lado inferior (Rossetti \& De Negri, 1990). Os ramos afetados podem apresentar entrenós curtos que conferem aspecto de "envassouramento" sendo que as gemas destes ramos tendem a brotar com maior freqüência e vigor dando origem a novos ramos doentes (Laranjeira, 1997). 
Segundo Machado et al. (1994), as folhas de plantas afetadas pela CVC apresentam sintomas de deficiência hídrica associados a decréscimos na taxa de fotossíntese, transpiração, condutância estomática e potencial de água.

Nos frutos os sintomas se expressam sempre após os sintomas foliares e em ramos já afetados. Há ocorrência de amarelecimento precoce, redução no tamanho e endurecimento, tornando-os imprestáveis para o comércio (Rossetti \& De Negri, 1990).

\subsubsection{Caracterização, disseminação e modo de ação}

A Xylella fastidiosa é uma bactéria gram negativa endofítica parasita que habita exclusivamente os elementos de vasos ou traqueídeos constituintes do xilema da planta hospedeira (Purcell \& Hopkins, 1996).

Weels et al. (1987) descrevem ainda como sendo uma bactéria não móvel, aeróbica estrita, não-fermentativa, não-halofítica e não-pigmentada, com hábito nutricional fastidioso. $\mathrm{O} \mathrm{pH}$ e temperatura ótimos de crescimento variam entre 6,5-6,9 e $26-28^{\circ} \mathrm{C}$, respectivamente.

Este parasita possui vários hospedeiros, entre eles mono e dicotiledôneas, incluindo espécies frutíferas, árvores, plantas ornamentais e ervas daninhas (Purcell \& Hopkins, 1996; Hopkins, 1989; Raju \& Wells, 1986; Lima et al., 1996; Leu \& Su, 1993 e Travensolo \& Leite Jr., 1996 ).

Os agentes vetores da Xylella fastidiosa são as cigarrinhas sugadoras de seiva do xilema, pertencentes às famílias Cicadellidae e Cercopidae da ordem Hemiptera subordem Homoptera (Gravena et al., 1997). As espécies comprovadamente transmissoras da bactéria à cultura da laranja são três: Dilopterus costalimai, Acrogonia sp. e Oncometopia facialis, mais conhecidas como: "Dilo", "Acro"e "Onco", as quais preferem se alimentar de hastes tenras logo abaixo das folhas dos ponteiros e de folhas novas e nas nervuras das folhas. Somente a "Onco" prefere ramos mais desenvolvidos, porém ainda não lenhoso (Yamamoto \& Roberto, 1997).

Os insetos destas duas famílias necessitam sugar grandes quantidades de seiva da planta, pois devido a baixa concentração de nutrientes, o aproveitamento é muito 
pequeno. Por esse motivo, estes insetos apresentam câmara de sucção hiperdesenvolvida com fortes músculos dilatadores que permitem a sucção da seiva mesmo em condições de tensão negativa no xilema (Gravena et al., 1997 ).

A bactéria, além de sobreviver no xilema, é capaz de alojar-se no aparelho bucal das cigarrinhas desde o momento de sua infecção em uma planta contaminada até sua fase adulta, fato que contribui muito para a disseminação da doença (Lopes., 1996).

Outra forma de transmissão da bactéria é por meio da enxertia de borbulhas infectadas (Jacomino et al., 1993) e também por garfagem de ramos afetados.

Existem várias hipóteses que explicam os mecanismos de patogenicidade da doença. Hopkins (1989) cita que os prejuízos podem ser causados devido às obstruções do sistema vascular pelas deposições de gomas pela bactéria, produção de toxinas (fitotoxinas) ou possíveis alterações hormonais causadas pela presença da bactéria.

Medina (2002a) trabalhando com plantas afetadas pela CVC em condições de deficiência hídrica encontrou como principal mecanismo de patogenicidade a obstrução dos vasos do xilema. Este resultado foi obtido com a observação de que folhas afetadas pela CVC apresentaram-se murchas durante o dia, com os estômatos parcialmente fechados, impedindo o acesso do $\mathrm{CO}_{2}$ na folha, interferindo na realização da fotossíntese e proporcionando redução no crescimento da planta e dos frutos. Foi constatado também que plantas com CVC submetidas a deficiência hídrica tiveram seus sintomas agravados e que folhas de plantas infectadas quando submetidas a menor pressão de vapor desidrataram-se mais rapidamente, inativando a fotossíntese, resultando em reflexos no crescimento da planta e dos frutos.

De acordo com Machado et al. (1994) plantas afetadas pela CVC apresentam disfunção no funcionamento dos estômatos, aumento na resistência ao fluxo da água ou absorção de água pelas raízes, tornando-as mais sensíveis à deficiência hídrica. Oliveira et al. (2000) observaram, em condições de campo, que laranjeiras das variedades Natal e Pêra com CVC apresentam fluxo de seiva até $70 \%$ menor que as plantas sadias. 


\subsubsection{Efeitos da doença na produção e qualidade dos frutos}

Palazzo (1993) estimando as perdas na produção da laranjeira da variedade Natal em dois anos consecutivos, decorrentes da ocorrência da CVC, observou que no primeiro ano as plantas doentes produziram maior quantidade de frutos, no entanto o peso médio dos frutos de plantas sadias foi superior ao das plantas doentes, provocando perda de produção de 19,7\%, devido a ocorrência da doença. No ano seguinte, tanto produção quanto o peso médio dos frutos, foram menores para plantas doentes em comparação às sadias, com ocorrência de perdas estimadas em 71,5\%.

Laranjeira \& Palazzo (1999) complementando o estudo iniciado em 1993, avaliaram os efeitos da incidência da CVC nas características físicas e químicas de frutos de plantas de laranja da variedade Natal. Os autores verificaram que as alterações foram mais relacionadas à diminuição no tamanho dos frutos do que a um efeito direto no metabolismo de ácidos e açúcares. Foram observados aumentos no ${ }^{\circ}$ Brix e no rendimento industrial de frutos afetados pela CVC, porém os autores justificaram que tal aumento é ilusório, tendo em vista que a quantidade total de sólidos solúveis diminuiu nos frutos de plantas doentes.

\subsubsection{Medidas de controle}

Segundo Feichtenberger et al. (1997) existem algumas sugestões para manejo de pomares com incidência de CVC, tais como: uso de mudas livres de Xylella fastidiosa em plantios novos e replantes; controle de plantas daninhas no pomar; realização de inspeções freqüentes nos pomares para identificar focos iniciais da doença; poda de ramos afetados (20-30 cm abaixo da última folha inferior com sintomas); manutenção do pomar em boas condições nutricionais e fitossanitárias e uso de quebra-vento.

É preciso saber que nenhuma destas medidas tomadas isoladamente ou em conjunto é capaz de impedir a disseminação do patógeno (Carvalho, 1996). É necessário proporcionar as melhores condições para bom desenvolvimento da cultura, 
principalmente em termos nutricionais, aumentando a resistência da planta à ocorrência de eventos adversos, entre eles a CVC.

Medina (2002b) cita que plantas bem nutridas e sem limitações nutricionais que impeçam as atividades metabólicas podem sobreviver melhor à CVC por atingir melhores taxas de fotossíntese e rápido crescimento, o que dilui a população bacteriana nos tecidos, pois as bactérias crescem lentamente, reduzindo seus efeitos deletérios. O contrário é observado em plantas subnutridas, as quais apresentam os sintomas da doença agravados. 


\section{MATERIAL E MÉTODOS}

\subsection{Localização da área experimental, variedade, tipo de solo e avaliação do estado nutricional}

O estudo foi conduzido em área de campo comercial da Fazenda Vale Verde (Cargill - Agrocitrus Ltda), no município de Comendador Gomes/MG, em um pomar de laranja em produção.

A variedade utilizada foi a Pêra-Rio (Citrus sinensis L. Osbeck) enxertada sobre Limão-Cravo (Citrus limonia L.Osbeck), instalada no ano de 1993 em espaçamento de $7 \mathrm{~m} \mathrm{X} \mathrm{3m,} \mathrm{correspondendo} \mathrm{à} \mathrm{população} \mathrm{de} 476$ plantas por hectare.

Devido ao fato das plantas da área experimental apresentarem sintomas típicos de infestação pela clorose variegada dos citros (CVC), foram excluídas das unidades experimentais as plantas que apresentavam sintomas graves da doença. A seleção foi realizada por intermédio da diagnose visual, utilizando a escala de notas proposta por Ayres (2000).

A escala baseia-se em notas, que podem variar de 0 a 3 de acordo com o nível de incidência da doença, a saber: nota 0 , ausência de sintomas; nota 1, plantas com sintomas restritos às folhas; nível 2, plantas apresentando um ramo com frutos de diâmetro inferior a $5 \mathrm{~cm}$ e com sintomas foliares que podem estar além deste ramo e nível 3, planta em definhamento, com frutos de diâmetro inferior a $5 \mathrm{~cm}$ em mais de um ramo e sintomas foliares generalizados.

O solo da área foi classificado como LATOSSOLO VERMELHO-AMARELO Distrófico psamítico (Embrapa, 1999), cujas características químicas por ocasião da instalação do experimento (setembro/2001) podem ser observadas nas Tabelas 1 e 2 . 
Tabela 1. Teores de macronutrientes e características químicas do solo da área experimental $^{(*)}$

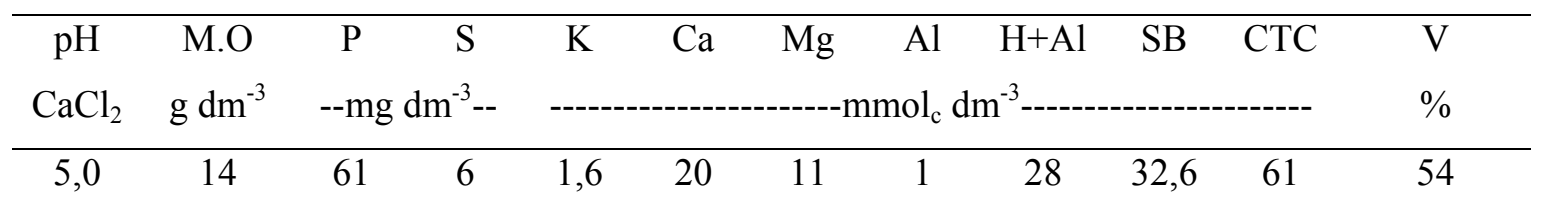

${ }^{(*)}$ profundidade de amostragem: $0-20 \mathrm{~cm}$.

$\mathrm{pH}-\mathrm{CaCl}_{2}$ 0,01 mol L-1 (Raij et al., 2001).

M.O. - Matéria orgânica, método colorimétrico (Raij et al., 2001).

P - Extração por resina trocadora de íons e determinação por colorimetria (Raij et al., 2001).

$\mathrm{S}-\mathrm{NH}_{4} \mathrm{OAc} 0,5 \mathrm{~N}$ em HOAc 0,25N (Vitti, 1988).

$\mathrm{K}$ - Extração por resina trocadora de íons e determinação por fotometria de chama (Raij et al., 2001).

$\mathrm{Ca}$ e $\mathrm{Mg}$ - Extração por resina trocadora de íons e determinação por espectrometria de absorção atômica (Raij et al., 2001).

$\mathrm{H}+\mathrm{Al}$ - Determinação por potenciometria em solução tampão SMP (Raij et al., 2001).

$\mathrm{Al}-\mathrm{KCl} 1 \mathrm{~N}$.

Tabela 2. Teores de micronutrientes no solo da área experimental ${ }^{(*)}$

\begin{tabular}{ccccc}
\hline $\mathrm{B}$ & $\mathrm{Cu}$ & $\mathrm{Fe}$ & $\mathrm{Mn}$ & $\mathrm{Zn}$ \\
\hline 0,78 & 3,5 & 46 & 3,2 & 2,6 \\
\hline
\end{tabular}

${ }^{(*)}$ profundidade de amostragem: 0-20 cm.

$\mathrm{B}-\mathrm{BaCl}_{2} .2 \mathrm{H}_{2} \mathrm{O} 0,125 \%$ microondas (Raij et al., 2001).

$\mathrm{Cu}, \mathrm{Fe}, \mathrm{Mn}, \mathrm{Zn}$ - DTPA-TEA pH 7,3 (Raij et al., 2001).

Com o intuito de avaliar o estado nutricional da cultura antes da instalação do experimento foram realizadas amostragens de folha (março/2001), no período recomendado por Malavolta et al. (1997). Os resultados podem ser observados na Tabela 3. 
Tabela 3. Teores foliares de macro e micronutrientes antes da instalação da área experimental

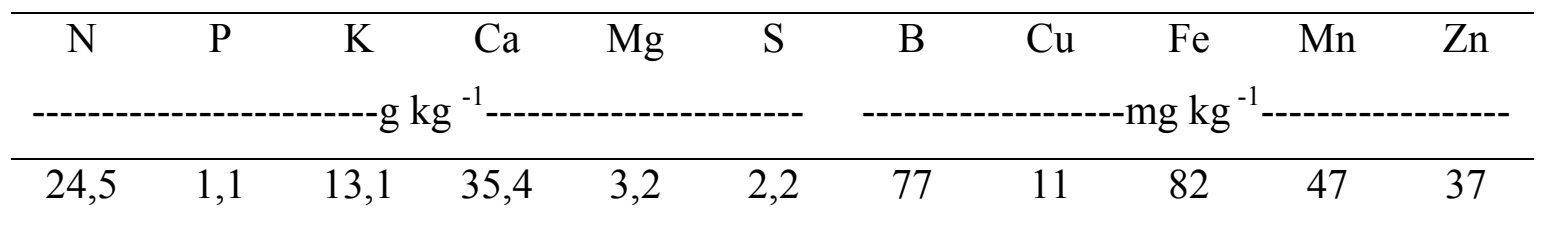

$\mathrm{N}$ - Digestão sulfúrica e determinação pelo método semi-micro Kjeldahl (Malavolta et al., 1997).

P- Digestão nítrico-perclórica e determinação por colorimetria (Malavolta et al., 1997) . K - Digestão nítrico-perclórica e determinação por fotometria de chama (Malavolta et al., 1997).

$\mathrm{Ca}, \mathrm{Mg}, \mathrm{Cu}, \mathrm{Fe}, \mathrm{Mn}, \mathrm{Zn}$ - Extração nítrico-perclórica e determinação por espectrometria de absorção (Malavolta et al., 1997).

S - Digestão nítrico-perclórica e determinação por turbidimetria do sulfato de bário (Malavolta et al., 1997).

B - Digestão seca e determinação por colorimetria da azometina-H (Malavolta et al., 1997).

Apesar da maioria dos nutrientes estarem dentro das faixas consideradas adequadas para a cultura, tanto no solo quanto foliarmente, especialmente no caso do boro, optou-se por manter a área experimental, tendo em vista a adequada distribuição dos sintomas da clorose variegada dos citros (CVC).

\subsection{Delineamento experimental}

O delineamento experimental utilizado foi o inteiramente casualizado, no esquema fatorial $5 \mathrm{X} 4$, com dois tratamentos adicionais, em quatro repetições, totalizando cem unidades experimentais. Cada unidade experimental constituiu-se de 5 plantas úteis, com 3 metros de espaçamento entre plantas e ainda 3 plantas utilizadas como bordadura. 


\subsection{Tratamentos}

Os tratamentos avaliados no experimento constituíram-se de seis fontes (ulexitapó, colemanita, ulexita-granulada, termofosfato magnesiano contendo boro, ácido bórico e termofosfato magnesiano sem boro), em quatro dosagens diferentes, incluindo o tratamento testemunha. Os tratamentos são visualizados na Tabela 4.

Tabela 4. Descrição dos tratamentos

\begin{tabular}{|c|c|c|c|c|}
\hline FONTE & $\begin{array}{c}\text { BORO } \\
\left(\text { g planta }^{-1}\right)\end{array}$ & $\begin{array}{c}\text { FONTE } \\
\left(\text { g planta }^{-1}\right)\end{array}$ & $\begin{array}{c}\text { BORO } \\
\left(\mathrm{kg} \mathrm{ha}^{-1}\right)\end{array}$ & $\begin{array}{c}\text { TERMOFOSFATO } \\
\text { MAGNESIANO } \\
\left(\text { g planta }^{-1}\right)\end{array}$ \\
\hline T1- Ulexita-pó & 2 & 17,4 & 1 & 525,2 \\
\hline T2- Ulexita-pó & 4 & 35,0 & 2 & 1050,4 \\
\hline T3- Ulexita-pó & 6 & 52,5 & 3 & 1575,6 \\
\hline T4- Ulexita-pó & 8 & 70,0 & 4 & 2100,8 \\
\hline T5- Colemanita-pó & 2 & 18,9 & 1 & 525,2 \\
\hline T6- Colemanita-pó & 4 & 37,8 & 2 & 1050,4 \\
\hline T7- Colemanita-pó & 6 & 56,7 & 3 & 1575,6 \\
\hline T8-Colemanita-pó & 8 & 75,6 & 4 & 2100,8 \\
\hline T9-Ulexita-gran. & 2 & 21,0 & 1 & 525,2 \\
\hline T10- Ulexita-gran. & 4 & 42,0 & 2 & 1050,4 \\
\hline T11- Ulexita-gran. & 6 & 63,0 & 3 & 1575,6 \\
\hline T12- Ulexita-gran. & 8 & 84,0 & 4 & 2100,8 \\
\hline T13- Termofosf.-B & 2 & 525,2 & 1 & - \\
\hline T14- Termofosf.-B & 4 & 1050,4 & 2 & - \\
\hline T15- Termofosf.-B & 6 & 1575,6 & 3 & - \\
\hline T16- Termofosf.-B & 8 & 2100,8 & 4 & - \\
\hline T17- Ácido bórico & 2 & 11,9 & 1 & 525,2 \\
\hline T18- Ácido bórico & 4 & 23,8 & 2 & 1050,4 \\
\hline T19- Ácido bórico & 6 & 35,7 & 3 & 1575,6 \\
\hline
\end{tabular}


Tabela 4. Descrição dos tratamentos

\begin{tabular}{lcccc}
\hline FONTE & $\begin{array}{c}\text { BORO } \\
\left(\mathrm{g} \mathrm{planta}^{-1}\right)\end{array}$ & $\begin{array}{c}\text { FONTE } \\
\left(\mathrm{g} \mathrm{planta}^{-1}\right)\end{array}$ & $\begin{array}{c}\text { BORO } \\
\left(\mathrm{kg} \mathrm{ha}^{-1}\right)\end{array}$ & $\begin{array}{c}\text { TERMOFOSFATO } \\
\text { MAGNESIANO } \\
\left(\mathrm{g} \mathrm{planta}^{-1}\right)\end{array}$ \\
\hline T20- Ácido bórico & 8 & 47,6 & 4 & 2100,8 \\
T21-Termof.-Mg & - & - & - & 525,2 \\
T22- Termof.-Mg & - & - & - & 1050,4 \\
T23- Termof.-Mg & - & - & - & 1575,6 \\
T24- Termof.-Mg & - & - & - & 2100,8 \\
T25- Testemunha & - & - & - & - \\
\hline
\end{tabular}

Na Tabela 5 visualiza-se a composição química das fontes utilizadas.

Tabela 5. Composição química dos produtos utilizados

\begin{tabular}{lcccccc}
\hline \multicolumn{1}{c}{ PRODUTO } & $\mathrm{B}$ & $\begin{array}{c}\mathrm{P}_{2} \mathrm{O}_{5} \\
\text { (total) }\end{array}$ & $\mathrm{Ca}$ & $\mathrm{Mg}$ & $\mathrm{S}$ & $\mathrm{SiO}_{2}$ \\
& & & & & \\
\hline Ulexita-pó & 12,0 & - & - & - & - & - \\
Colemanita-pó & 11,0 & - & - & - & - & - \\
Ulexita-granulada & 10,0 & - & - & - & 4,0 & - \\
Termofosfato-B & 0,40 & 18,0 & 20,0 & 9,0 & - & 23,0 \\
Ácido bórico & 17,0 & - & - & - & - & - \\
Termofosfato & - & 18,0 & 20,0 & 9,0 & - & 23,0 \\
\hline
\end{tabular}

Os tratamentos com boro receberam as mesmas dosagens de fósforo, cálcio, magnésio e silício que foram adicionadas pelo tratamento de termofosfato com boro, com o intuito de balancear os demais nutrientes não adicionados pelas fontes de boro que não os contém. A adição destes nutrientes foi realizada pela adição de termofosfato magnesiano. 


\subsection{Calagem, adubações de cobertura e tratos culturais}

Foi realizada calagem no mês de junho de 2001 (antes da instalação do experimento), com a aplicação de calcário calcítico na dose de uma tonelada por hectare, com o intuito de elevar a saturação por bases para $70 \%$, conforme o recomendado para a cultura.

As adubações de cobertura com nitrogênio e potássio foram realizadas no mês de outubro de 2001 (após a instalação do experimento), utilizando-se como fonte de nitrogênio o nitrato de amônio na dosagem de $352 \mathrm{~g}$ por planta e como fonte de potássio o cloreto de potássio na dose de 130 g por planta. Não foram realizadas adubações de cobertura com fósforo.

Foram realizadas 3 pulverizações com adubo foliar quelatizado, nos meses de outubro/2001, janeiro/2002 e março/2002, na dose de 6,4 L por planta. A composição do

adubo foliar segue as seguintes garantias: N 10\% (129 $\left.\mathrm{g} \mathrm{L}^{-1}\right), \mathrm{Zn} \mathrm{4 \%}\left(51,6 \mathrm{~g} \mathrm{~L}^{-1}\right), \mathrm{Mn}$ $2 \%\left(25,8 \mathrm{~g} \mathrm{~L}^{-1}\right), \operatorname{Mg} 2 \%\left(25,8 \mathrm{~g} \mathrm{~L}^{-1}\right)$ e $\mathrm{B} 0,5 \%\left(6,45 \mathrm{~g} \mathrm{~L}^{-1}\right)$.

O manejo fitossanitário e controle de ervas daninhas do pomar foram os mesmos utilizados como padrão da fazenda, seguindo as recomendações técnicas para a cultura.

\subsection{Instalação do experimento}

A instalação do experimento foi realizada no mês de setembro de 2001, quando foram feitas as demarcações da área e escolha das plantas a serem utilizadas experimentalmente. A escolha obedeceu a escala de nível de incidência de CVC, de acordo com o citado por Ayres (2000), excluindo-se as árvores que apresentavam sintomas mais severos da doença.

Os tratamentos foram aplicados no solo, manualmente, de forma localizada, em faixa lateral de projeção da copa. 


\subsection{Amostragem e análise de folhas}

Foram coletadas amostras de folhas no mês de fevereiro de 2002, seis meses após aplicação dos tratamentos. Coletaram-se as folhas recém-maduras, geradas na primavera e de ramos com frutos, totalizando 4 folhas por planta, uma de cada quadrante na altura mediana da planta, tomando-se o cuidado de amostrar a $3^{\mathrm{a}}$ ou $4^{\mathrm{a}}$ folha à partir do fruto, perfazendo um total de 20 folhas por parcela.

Após a coleta, as amostras foram armazenadas em sacos de papel identificados e levadas ao laboratório. As folhas frescas foram submetidas à lavagem inicialmente em água deionizada, a seguir com detergente neutro e em seguida em solução de $\mathrm{HCl} 3 \%$ e uma última lavagem com água deionizada. Imediatamente após a lavagem as amostras foram submetidas a secagem em estufa com circulação forçada de ar na temperatura de $65^{\circ} \mathrm{C}$ e moagem em moinho do tipo Wiley com peneira de 20 mesh.

O material moído foi analisado para determinação de $\mathrm{P}, \mathrm{Ca}, \mathrm{Mg}, \mathrm{B}, \mathrm{Si} . \mathrm{O}$ fósforo, cálcio, magnésio foram extraídos pela digestão nítrico-perclórica, o boro pela digestão seca e o silício pela digestão em auto-clave. As determinações analíticas foram realizadas de acordo com as metodologias descritas por Malavolta et al. (1997).

Também foi avaliada as relações Ca:B no tecido foliar, com o intuito de analisar o estado nutricional para boro.

\subsection{Amostragem e análise de solo}

Foram realizadas amostragens de solo no mês de julho de 2002, onze meses após a aplicação dos tratamentos, em todas as parcelas experimentais, obedecendo-se o prazo de sessenta dias após a última adubação de cobertura. Foram coletadas amostras de solo na profundidade de $0-20 \mathrm{~cm}$, com o uso de sonda, abrangendo toda a faixa adubada dos dois lados da planta, totalizando 10 sub-amostras por parcela.

As amostras foram acondicionadas em sacos plásticos identificados e encaminhadas para o laboratório, onde foram secas em estufa de circulação forçada, com 
temperatura não superior a $40^{\circ} \mathrm{C}$. Após a secagem, foram feitas determinações de $\mathrm{P}, \mathrm{Ca}$, $\mathrm{Mg}$ e B, conforme as metodologias propostas por Raij et al. (2001).

\subsection{Determinação de produtividade e qualidade tecnológica}

A colheita do experimento foi realizada no mês de agosto de 2002. Para determinação da produtividade, colheram-se todos frutos das cinco plantas tratadas de cada parcela experimental e pesou-se a produção total destas cinco árvores. Com o resultado da produção de cada parcela, calculou-se a produção em toneladas por hectare.

Por ocasião da colheita também foi realizada amostragem para avaliação da qualidade tecnológica dos frutos, tomando-se uma amostra composta por 36 frutos por parcela. As amostras foram acondicionadas em sacos de ráfia, identificados e enviados no mesmo dia para análise no laboratório da indústria da Cargill Agrocitrus Ltda., na cidade de Bebedouro. Foram determinados sólidos solúveis, ${ }^{\circ}$ BRIX, Ratio, \% de suco e número de frutos por caixa.

No momento da colheita também foi retirada uma amostra composta de 10 frutos por parcela para avaliação de parâmetros físicos do fruto, como diâmetro e espessura de casca, sendo estas medições realizadas com auxílio de paquímetro graduado em milímetro.

\subsection{Análise estatística}

Os dados obtidos foram analisados inicialmente considerando 25 tratamentos através do teste $\mathrm{F}$ da análise da variância e posteriormente através do teste de Tukey a nível de 5\% de probabilidade. Para completar a análise foi desdobrado o fatorial 5X4 aplicando o teste de Tukey para fontes e regressão polinomial para doses. 


\section{RESULTADOS E DISCUSSÃO}

\subsection{Avaliação do estado nutricional da cultura}

$\mathrm{Na}$ Tabela 6 observa-se a influência da aplicação dos tratamentos nos teores foliares de fósforo $(\mathrm{P})$, cálcio $(\mathrm{Ca})$, magnésio $(\mathrm{Mg})$, silício $(\mathrm{Si})$, boro $(\mathrm{B})$, bem como a relação cálcio/boro (Ca:B), seis meses após a aplicação dos mesmos. Verifica-se que não houve diferença estatística significativa nos níveis foliares de $\mathrm{P}, \mathrm{Ca}, \mathrm{Mg}$ e $\mathrm{Si}$. Os teores de fósforo mantiveram-se ligeiramente abaixo da faixa considerada adequada para a cultura (1,2-1,6 $\left.\mathrm{g} \mathrm{kg}^{-1}\right)$, conforme citado por Malavolta et al. (1997) e GPACC (1994), indicando que a adubação fosfatada adicionada em todos os tratamentos, excluindo-se a testemunha, por meio do termofosfato magnesiano, não foi eficiente para elevar os teores de fósforo foliar aos níveis considerados adequados no período avaliado. Os teores de cálcio encontram-se adequados para cultura, de acordo com Malavolta et al. (1997) (30-49), porém de acordo com GPACC (1994)(35-45 $\mathrm{g} \mathrm{kg}^{-1}$ ) os tratamentos T15 $(34,4)$ e T18 $\left(33,3 \mathrm{~g} \mathrm{~kg}^{-1}\right)$ encontram-se abaixo dos níveis de suficiência. O mesmo ocorre para o magnésio, pois de acordo com GPACC (1994) todos os teores são considerados adequados (2,5-4,0), porém em T6 $(2,8)$ e T19 $\left(2,9 \mathrm{~g} \mathrm{~kg}^{-1}\right)$, de acordo com Malavolta et al. (1997) (3-5 $\left.\mathrm{g} \mathrm{kg}^{-1}\right)$ são considerados baixos. Os teores de silício em todos os tratamentos, inclusive a testemunha, encontram-se acima do apresentado por Matichenkov et al. (1999) para a cultura dos citros (1,3-3,6 $\left.\mathrm{g} \mathrm{kg}^{-1}\right)$.

Pode-se observar que houve diferença estatística significativa nos teores de B e na relação $\mathrm{Ca}: \mathrm{B}$, de acordo com os tratamentos aplicados. Os maiores teores de boro na folha podem ser observados em T20 (283), T4 (270), T3 (255), T19 (248) e T8 (228 mg

$\mathrm{kg}^{-1}$ ), os quais correspondem, respectivamente, as fontes ácido bórico, ulexita-pó, ácido 
bórico e colemanita nas doses de 4, 4, 3, 3 e $4 \mathrm{~kg}$ de boro $\mathrm{ha}^{-1}$. Os menores teores de boro foram observados nos tratamentos T22 (109), T14 (106), T13 (106), T23 (106) e T24 (91 $\mathrm{mg} \mathrm{kg}^{-1}$ ), respectivamente, termofosfato magnesiano sem boro, termofosfato com boro, termofosfato com boro, termofosfato magnesiano sem boro e termofosfato magnesiano sem boro, nas doses $0 \mathrm{~kg} \mathrm{~B} \mathrm{ha}^{-1}$ (500 kg de termofosfato ha ${ }^{-1}$ ), $2 \mathrm{~kg}$ de B ha ${ }^{1}$ (500 kg de termofosfato ha $\left.{ }^{-1}\right), 1 \mathrm{~kg}$ de B ha $^{-1}\left(250 \mathrm{~kg}\right.$ de termofosfato ha $\left.{ }^{-1}\right), 0 \mathrm{~kg}$ de B $\mathrm{ha}^{-1}\left(750 \mathrm{~kg} \mathrm{ha}^{-1}\right)$ e $0 \mathrm{~kg}$ de B ha ${ }^{-1}\left(1000 \mathrm{~kg}\right.$ de termofosfato ha $\left.{ }^{-1}\right)$. Houve aumento nos teores foliares de boro em todos os tratamentos, inclusive a testemunha e os tratamentos com aplicação apenas de termofosfato magnesiano, indicando que as duas pulverizações foliares, realizadas antes o período de amostragem das folhas, com produto contendo boro foram eficiente no fornecimento do nutriente, contrariando o observado por Cabrita (1993). Observa-se ainda que nos tratamentos T20 (ácido bórico, $4 \mathrm{~kg}$ de B ha ${ }^{-1}$ ), T4 (ulexita-pó, $4 \mathrm{~kg}$ de $\mathrm{B} \mathrm{ha}{ }^{-1}$ ) e T3 (ulexita-pó, $3 \mathrm{~kg}$ de $\mathrm{B} \mathrm{ha}^{-1}$ ) os teores foliares de boro ultrapassaram a faixa considerada excessiva $\left(>250 \mathrm{mg} \mathrm{kg}^{-1}\right)$, conforme o citado por GPACC (1994), sem que tenha ocorrido aparecimento de sintomas de toxidez por boro, conforme o sugerido por Smith (1955), indicando maior solubilidade dessas fontes em relação principalmente à colemanita, fonte esta que apresenta o boro ligado a cálcio.

A relação $\mathrm{Ca}: \mathrm{B}$ é usada como indicadora do estado nutricional para boro. Observa-se que a maior relação Ca:B (435) foi encontrada no T24 (0 kg de B ha ${ }^{-1}$ e 1000 $\mathrm{kg}$ de termofosfato magnesiano $\mathrm{ha}^{-1}$ ) e o menor valor (128) no T20 (ácido bórico, $4 \mathrm{~kg}$ de $\mathrm{B} \mathrm{ha}^{-1}$ e $1000 \mathrm{~kg}$ de termofosfato ha ${ }^{-1}$ ), confirmando-se que o uso de fontes com altos teores de boro solúvel elevam os teores de boro nas folhas, reduzindo a relação Ca:B. 
Tabela 6. Teores foliares de $\mathrm{P}, \mathrm{Ca}, \mathrm{Mg}, \mathrm{Si}, \mathrm{B}$ e relação $\mathrm{Ca}: \mathrm{B}$

\begin{tabular}{|c|c|c|c|c|c|c|}
\hline Tratamento & $\begin{array}{c}\mathrm{P} \\
-\end{array}$ & $\mathrm{Ca}$ & $\mathrm{Mg}$ & $\mathrm{Si}$ & $\begin{array}{c}\text { B } \\
---\mathrm{mg} \mathrm{kg}^{-1}---\end{array}$ & $\mathrm{Ca}: \mathrm{B}$ \\
\hline $\mathrm{T} 1$ & $1,1 \mathrm{a}$ & $35,9 a$ & $3,2 \mathrm{a}$ & $4,6 a$ & 139efghij & 264,2bcdefgh \\
\hline $\mathrm{T} 2$ & $1,1 \mathrm{a}$ & $39,0 \mathrm{a}$ & $3,8 \mathrm{a}$ & $4,5 \mathrm{a}$ & 195bcdefgh & 211,7defghi \\
\hline $\mathrm{T} 3$ & $1,1 \mathrm{a}$ & $36,8 \mathrm{a}$ & $3,4 a$ & $3,6 a$ & $255 \mathrm{abc}$ & $146,7 \mathrm{hi}$ \\
\hline $\mathrm{T} 4$ & $1,1 \mathrm{a}$ & $36,8 \mathrm{a}$ & $3,6 a$ & $3,5 \mathrm{a}$ & $270 \mathrm{ab}$ & 139,2hi \\
\hline $\mathrm{T} 5$ & $1,1 \mathrm{a}$ & $38,0 \mathrm{a}$ & $3,3 a$ & $4,5 \mathrm{a}$ & 132fghij & 294,7 bcdefg \\
\hline T6 & $1,1 \mathrm{a}$ & $37,5 \mathrm{a}$ & $2,8 \mathrm{a}$ & $4,7 \mathrm{a}$ & $216 \mathrm{abcde}$ & 180,7ghi \\
\hline $\mathrm{T} 7$ & $1,0 \mathrm{a}$ & $39,9 a$ & $3,3 a$ & $4,1 \mathrm{a}$ & 197bcdefg & 203,0efghi \\
\hline $\mathrm{T} 8$ & $1,1 \mathrm{a}$ & $35,5 a$ & $3,6 a$ & $3,4 a$ & $228 \mathrm{abcd}$ & 160,0hi \\
\hline T9 & $1,0 \mathrm{a}$ & $36,8 \mathrm{a}$ & $3,2 \mathrm{a}$ & $5,0 \mathrm{a}$ & 124ghij & $301,7 \mathrm{bcdefg}$ \\
\hline $\mathrm{T} 10$ & $1,0 \mathrm{a}$ & $36,2 \mathrm{a}$ & $3,4 a$ & $4,1 \mathrm{a}$ & 159defghij & 229,2cdefghi \\
\hline $\mathrm{T} 11$ & $1,0 \mathrm{a}$ & $36,4 a$ & $3,2 \mathrm{a}$ & $4,0 \mathrm{a}$ & 181cdefghi & 201,0efghi \\
\hline $\mathrm{T} 12$ & $1,0 \mathrm{a}$ & $39,1 \mathrm{a}$ & $3,3 a$ & $4,4 a$ & 207abcdef & 195,2fghi \\
\hline $\mathrm{T} 13$ & $1,1 \mathrm{a}$ & $36,3 a$ & $3,3 a$ & $3,9 \mathrm{a}$ & $106 \mathrm{ij}$ & $353,7 \mathrm{abc}$ \\
\hline $\mathrm{T} 14$ & $1,0 \mathrm{a}$ & $37,5 \mathrm{a}$ & $3,4 a$ & $4,2 \mathrm{a}$ & $106 \mathrm{ij}$ & $362,5 \mathrm{ab}$ \\
\hline $\mathrm{T} 15$ & $1,1 \mathrm{a}$ & $34,4 \mathrm{a}$ & $3,4 a$ & $3,8 \mathrm{a}$ & $114 \mathrm{ij}$ & $306,2 \mathrm{abcdefg}$ \\
\hline $\mathrm{T} 16$ & $1,0 \mathrm{a}$ & $35,9 a$ & $3,2 \mathrm{a}$ & $3,8 \mathrm{a}$ & 119ghij & $312,5 \mathrm{abcdef}$ \\
\hline $\mathrm{T} 17$ & $0,9 \mathrm{a}$ & $37,1 \mathrm{a}$ & $3,2 \mathrm{a}$ & $4,2 \mathrm{a}$ & 152defghij & 249,2 bcdefghi \\
\hline $\mathrm{T} 18$ & $1,0 \mathrm{a}$ & $33,3 \mathrm{a}$ & $3,0 \mathrm{a}$ & $4,1 \mathrm{a}$ & $204 \mathrm{bcdef}$ & $163,5 \mathrm{hi}$ \\
\hline T19 & $1,0 \mathrm{a}$ & $35,8 \mathrm{a}$ & $2,9 a$ & $4,0 \mathrm{a}$ & $248 \mathrm{abc}$ & 145,0hi \\
\hline $\mathrm{T} 20$ & $1,0 \mathrm{a}$ & $36,1 \mathrm{a}$ & $3,3 a$ & $3,9 \mathrm{a}$ & $283 a$ & $128,2 \mathrm{i}$ \\
\hline $\mathrm{T} 21$ & $1,0 \mathrm{a}$ & $37,0 \mathrm{a}$ & $3,2 \mathrm{a}$ & $4,1 \mathrm{a}$ & $114 \mathrm{ij}$ & $328,2 \mathrm{abcde}$ \\
\hline $\mathrm{T} 22$ & $1,0 \mathrm{a}$ & $35,8 \mathrm{a}$ & $3,4 a$ & $4,0 \mathrm{a}$ & $109 \mathrm{ij}$ & 330,2 abcde \\
\hline $\mathrm{T} 23$ & $1,0 \mathrm{a}$ & $34,9 a$ & $3,3 a$ & $4,0 \mathrm{a}$ & $106 \mathrm{ij}$ & $335,7 \mathrm{abcd}$ \\
\hline $\mathrm{T} 24$ & $1,1 \mathrm{a}$ & $39,2 \mathrm{a}$ & $3,9 \mathrm{a}$ & $5,2 \mathrm{a}$ & $91 \mathrm{j}$ & $435,2 \mathrm{a}$ \\
\hline $\mathrm{T} 25$ & $1,1 \mathrm{a}$ & $37,2 \mathrm{a}$ & $3,7 \mathrm{a}$ & $3,7 \mathrm{a}$ & 118hij & $324,7 \mathrm{abcdef}$ \\
\hline Valor F & $1,1 \mathrm{~ns}$ & $0,7 \mathrm{~ns}$ & $0,8 \mathrm{~ns}$ & $0,8 \mathrm{~ns}$ & $16,3 * *$ & $12,3 * *$ \\
\hline CV (\%) & 8,2 & 9,7 & 17,0 & 23,9 & 17,6 & 19,2 \\
\hline DMS & 0,2 & 9,6 & 1,5 & 2,6 & 78,8 & 130,2 \\
\hline
\end{tabular}

Médias de quatro repetições contidas em colunas, seguidas de mesma letra não diferem entre si pelo teste de Tukey. ${ }^{*}$ e ${ }^{* *}$ : nível de significância de 5 e $1 \%$ respectivamente. ns: não significativo

Com relação aos tratamentos envolvendo apenas fontes de boro, pode-se observar que não houve diferença estatística significativa no teor de fósforo foliar para as fontes testadas (Tabela 7). Este resultado deve-se ao fato de todos os tratamentos terem recebido adição de fósforo, por meio do termofosfato magnesiano, a fim de se balancear os nutrientes destas fontes com os presentes no termofosfato com boro. $\mathrm{O}$ 
mesmo observa-se para o magnésio (Tabela 8), indicando fornecimento balanceado de outros nutrientes, não envolvidos no estudo.

Tabela 7. Teores foliares de fósforo, em $\mathrm{g} \mathrm{kg}^{-1}$, nas diferentes fontes e doses de boro utilizadas

\begin{tabular}{lcccc}
\hline Fonte & \multicolumn{4}{c}{ Doses B $\left(\mathrm{kg} \mathrm{ha}^{-1}\right)$} \\
& 1 & 2 & 3 & 4 \\
\hline Ulexita- pó & $1,0 \mathrm{a}$ & $1,0 \mathrm{a}$ & $1,1 \mathrm{a}$ & $1,1 \mathrm{a}$ \\
Colemanita- pó & $1,1 \mathrm{a}$ & $1,1 \mathrm{a}$ & $1,0 \mathrm{a}$ & $1,1 \mathrm{a}$ \\
Ulexita- gran. & $1,0 \mathrm{a}$ & $1,0 \mathrm{a}$ & $1,0 \mathrm{a}$ & $1,0 \mathrm{a}$ \\
Termofosfato-B & $1,1 \mathrm{a}$ & $1,0 \mathrm{a}$ & $1,1 \mathrm{a}$ & $1,0 \mathrm{a}$ \\
Ácido bórico & $0,9 \mathrm{a}$ & $1,0 \mathrm{a}$ & $1,0 \mathrm{a}$ & $1,0 \mathrm{a}$ \\
\hline
\end{tabular}

Médias de quatro repetições seguidas de mesma letra na coluna não diferem entre si pelo teste de Tukey a 5\% de significância

Tabela 8. Teores foliares de magnésio, em $\mathrm{g} \mathrm{kg}^{-1}$, nas diferentes fontes e doses de boro utilizadas

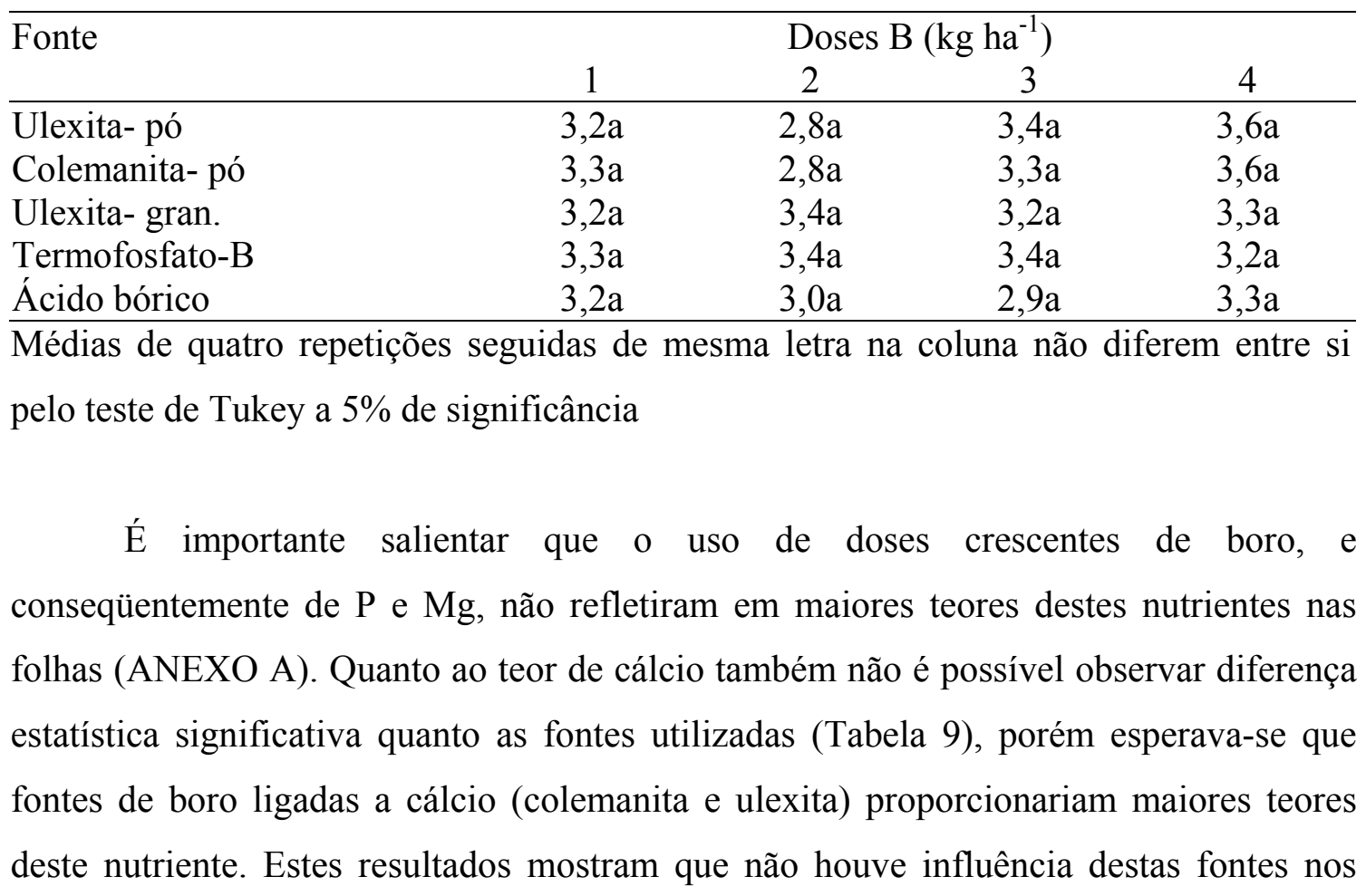


teores de cálcio, e sim influência do uso do termofosfato magnesiano, que possue $20 \%$ de cálcio em sua composição ou ainda da calagem realizada no mês de junho de 2001, com o uso de calcário calcítico, os quais acrescentam proporcionalmente maiores quantidades de cálcio, em relação às fontes de boro contendo esse nutriente.

Tabela 9. Teores foliares de cálcio, em $\mathrm{g} \mathrm{kg}^{-1}$, nas diferentes fontes e doses de boro utilizadas

\begin{tabular}{lcccc}
\hline Fonte & \multicolumn{4}{c}{ Doses B $\left(\mathrm{kg} \mathrm{ha}^{-1}\right)$} \\
& 1 & 2 & 3 & 4 \\
\hline Ulexita- pó & $35,9 \mathrm{a}$ & $39,0 \mathrm{a}$ & $36,8 \mathrm{a}$ & $36,8 \mathrm{a}$ \\
Colemanita- pó & $38,0 \mathrm{a}$ & $37,5 \mathrm{a}$ & $39,9 \mathrm{a}$ & $35,5 \mathrm{a}$ \\
Ulexita- gran. & $36,8 \mathrm{a}$ & $36,2 \mathrm{a}$ & $36,4 \mathrm{a}$ & $39,1 \mathrm{a}$ \\
Termofosfato-B & $36,3 \mathrm{a}$ & $37,5 \mathrm{a}$ & $34,4 \mathrm{a}$ & $35,9 \mathrm{a}$ \\
Ácido bórico & $37,1 \mathrm{a}$ & $33,3 \mathrm{a}$ & $35,8 \mathrm{a}$ & $36,1 \mathrm{a}$ \\
\hline
\end{tabular}

Médias de quatro repetições seguidas de mesma letra na coluna não diferem entre si pelo teste de Tukey a 5\% de significância

$\mathrm{Na}$ Tabela 10 pode-se observar que o uso de diferentes fontes de boro não influenciaram significativamente os teores de silício foliar, porém na Figura 1 observase efeito linear negativo significativo $(p>0,05)$ do aumento das doses de boro na diminuição dos teores foliares de silício. Este resultado explica-se pelo fato de que junto com o aumento das doses de boro foram adicionadas maiores quantidades de termofosfato magnesiano, o qual contém P e Si em sua composição. Os ânions fosfato e silicato possuem comportamento semelhante no solo, o qual caracteriza-se pela capacidade de adsorção às superfícies dos óxidos de ferro e alumínio da fração argila, havendo inclusive competição entre o Si e o P pelos mesmos sítios de adsorção. Porém o silício têm preferência na ordem de fixação e sua aplicação no solo reduz a fixação e aumenta a disponibilidade do fósforo (Sanchez \& Uehara, 1980); portanto a adição de doses crescentes de silício através do uso de termofostato não foram suficientes para promover maiores teores de silício foliar devido, provavelmente, ao maior grau de fixação deste elemento no solo. Resultados semelhantes foram obtidos por Rothbur \& Scott (1957), utilizando silício radioativo, mostraram que a adição de fósforo reduz a 
quantidade de silício absorvida pelo trigo. Roy ${ }^{1}$ citado por Gurgel (1979) também mostrou que a presença de fósforo em solução nutritiva inibiu a absorção de silício pela planta, sendo maior essa inibição quando ambos os nutrientes foram fornecidos às plantas nas mesmas proporções.

Tabela 10. Teores foliares de silício, em $\mathrm{g} \mathrm{kg}^{-1}$, nas diferentes fontes e doses de boro utilizadas

\begin{tabular}{lcccc}
\hline Fonte & \multicolumn{4}{c}{ Doses B $\left(\mathrm{kg} \mathrm{ha}^{-1}\right)$} \\
& 1 & 2 & 3 & 4 \\
\hline Ulexita- pó & $4,6 \mathrm{a}$ & $4,5 \mathrm{a}$ & $3,6 \mathrm{a}$ & $3,5 \mathrm{a}$ \\
Colemanita- pó & $4,5 \mathrm{a}$ & $4,7 \mathrm{a}$ & $4,1 \mathrm{a}$ & $3,4 \mathrm{a}$ \\
Ulexita- gran. & $5,0 \mathrm{a}$ & $4,1 \mathrm{a}$ & $4,0 \mathrm{a}$ & $4,4 \mathrm{a}$ \\
Termofosfato-B & $3,9 \mathrm{a}$ & $4,2 \mathrm{a}$ & $3,8 \mathrm{a}$ & $3,8 \mathrm{a}$ \\
Ácido bórico & $4,2 \mathrm{a}$ & $4,1 \mathrm{a}$ & $4,0 \mathrm{a}$ & $3,9 \mathrm{a}$ \\
\hline
\end{tabular}

Médias de quatro repetições seguidas de mesma letra na coluna não diferem entre si pelo teste de Tukey a 5\% de significância

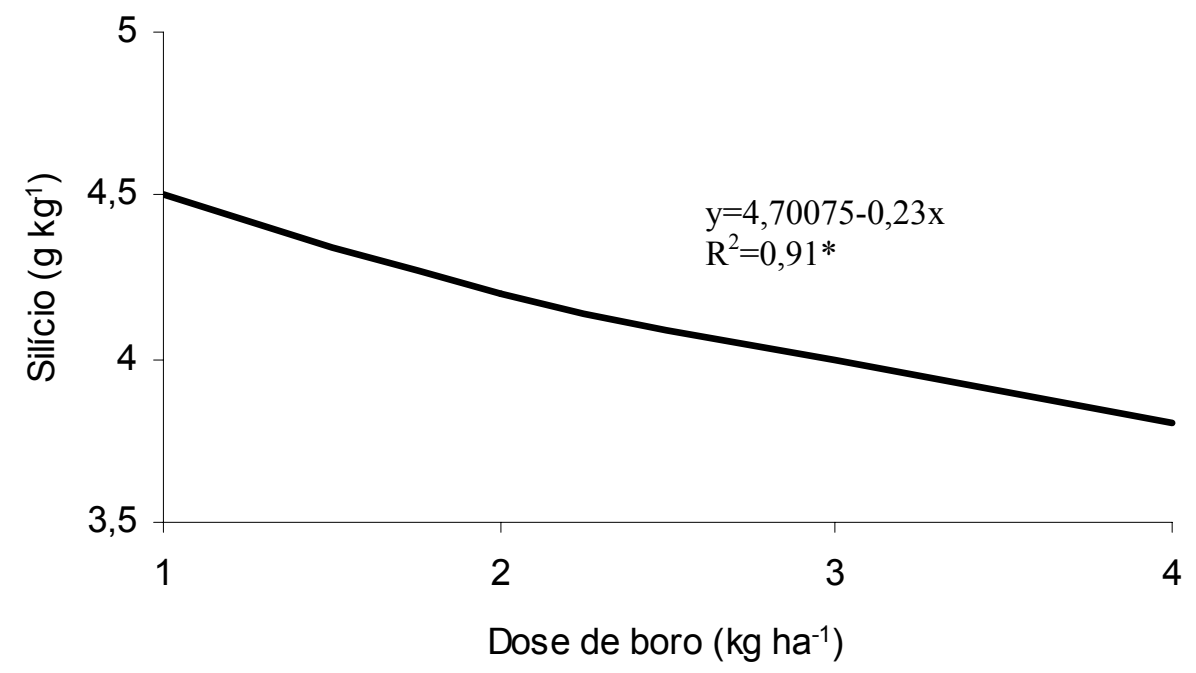

Figura 1- Correlação entre doses de boro aplicadas no solo e teores foliares de silício

\footnotetext{
${ }^{1}$ ROY, A.C. Phosphorus-silicon interactions in soils and plants. Ph.D. Thesis, University of Hawaii, 1969. 190p.
} 
Em relação ao teor de boro foliar e o uso de diferentes fontes do mesmo, pode-se observar na Tabela 11 que dentro de todas as doses testadas, o termofosfato com boro proporcionou os menores teores foliares do elemento, o que pode ser explicado pela menor solubilidade, enquanto que o ácido bórico e a ulexita-pó proporcionaram maiores teores, seja pela maior solubilidade do ácido bórico e da ulexita por ter parte do boro ligado a sódio, aliada a sua forma em pó, permitindo maior contato com o solo e conseqüentemente maiores condições de solubilização.

Tabela 11. Teores foliares de boro, em $\mathrm{mg} \mathrm{kg}^{-1}$, nas diferentes fontes e doses de boro utilizadas

\begin{tabular}{lcccc}
\hline Fonte & \multicolumn{4}{c}{ Doses B $\left(\mathrm{kg} \mathrm{ha}^{-1}\right)$} \\
& 1 & 2 & 3 & 4 \\
\hline Ulexita- pó & $139 \mathrm{a}$ & $195 \mathrm{a}$ & $255 \mathrm{a}$ & $270 \mathrm{a}$ \\
Colemanita- pó & $132 \mathrm{a}$ & $217 \mathrm{a}$ & $197 \mathrm{ab}$ & $228 \mathrm{ab}$ \\
Ulexita- gran. & $124 \mathrm{a}$ & $159 \mathrm{ab}$ & $181 \mathrm{~b}$ & $207 \mathrm{~b}$ \\
Termofosfato-B & $106 \mathrm{a}$ & $106 \mathrm{~b}$ & $114 \mathrm{c}$ & $119 \mathrm{c}$ \\
Ácido bórico & $152 \mathrm{a}$ & $204 \mathrm{a}$ & $248 \mathrm{a}$ & $283 \mathrm{a}$ \\
\hline
\end{tabular}

Médias de quatro repetições seguidas de mesma letra na coluna não diferem entre si pelo teste de Tukey a $1 \%$ de significância

Na Tabela 12 retifica-se, através da média do teor foliar de boro para cada fonte testada, que o ácido bórico é a que proporciona os maiores teores foliares de boro no ano da aplicação dos tratamentos, sem diferir estatisticamente dos tratamentos com ulexitapó e colemanita-pó. Observa-se que a colemanita-pó e a ulexita-granulada não diferiram estatisticamente, confirmando o citado por Byers et al. (2001) que a granulometria da ulexita influencia diretamente sua solubilidade, portanto quando comparamos uma fonte menos solúvel como a colemanita (a qual apresenta todo boro ligado a cálcio), porém aplicada na forma de pó, com uma fonte considerada mais solúvel como a ulexita (parte do boro ligado a cálcio e parte ligado a sódio), porém na forma granulada, observa-se não haver diferença significativa entre os teores de boro. $\mathrm{O}$ termofosfato com boro continua sendo a fonte que proporciona os menores teores de boro foliar no ano de sua aplicação. 
Tabela 12. Média dos teores foliares de boro para cada fonte utilizada

\begin{tabular}{lc}
\hline Fonte & $\mathrm{B}\left(\mathrm{mg} \mathrm{kg}^{-1}\right)$ \\
\hline Ácido bórico & $222 \mathrm{a}$ \\
Ulexita-pó & $215 \mathrm{a}$ \\
Colemanita-pó & $194 \mathrm{ab}$ \\
Ulexita-gran. & $168 \mathrm{~b}$ \\
Termofosfato-B & $111 \mathrm{c}$ \\
Valor F & $55,8^{* *}$ \\
CV $(\%)$ & 13,1 \\
DMS & 28,9 \\
\hline
\end{tabular}

Médias de quatro doses e quatro repetições seguidas de mesma letra não diferem entre si pelo teste de Tukey a $1 \%$ de significância. **: nível de significância de $1 \%$

Também pode-se observar na Figura 2 a influência significativa do aumento das doses de boro nos teores foliares deste elemento. Todas as fontes, excluindo-se o termofosfato com boro, proporcionaram aumento significativo $(\mathrm{p}>0,01)$ e linear nos teores de boro foliar com o aumento progressivo das doses, sendo que o ácido bórico, a ulexita granulada, a ulexita-pó foram as fontes que apresentaram os maiores coeficientes de determinação $\left(\mathrm{R}^{2}\right)$ a 1\% de significância, respectivamente: $0,99,0,99$ e 0,95 .

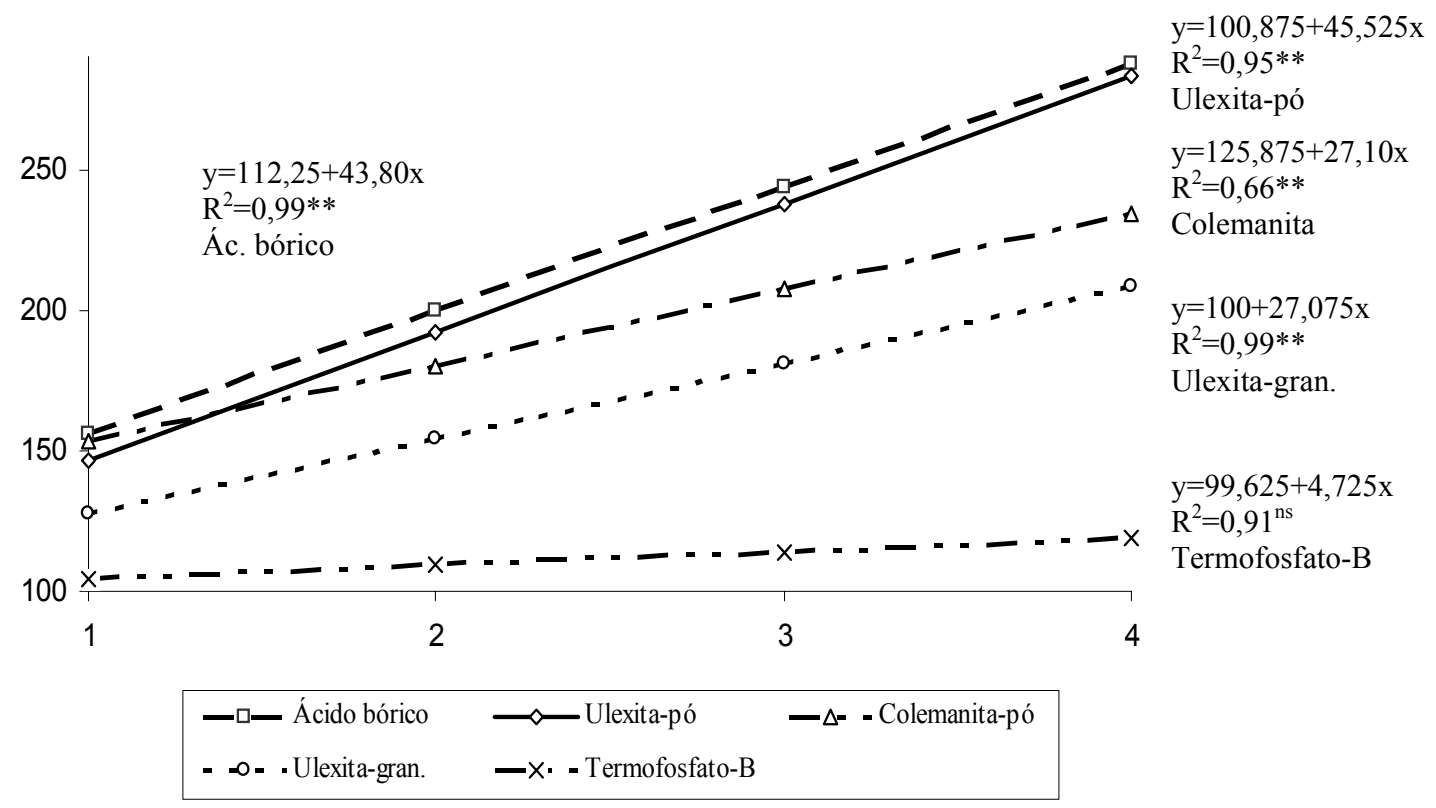

Figura 2- Correlação entre as doses de boro aplicadas no solo e teores foliares de boro 
A relação Ca:B, conforme citado por Gupta (1993), é indicadora do estado nutricional de boro na planta. Elevadas relações (entre 1000 e 3000) indicam predomínio de cálcio no tecido foliar e conseqüentemente maior suscetibilidade ao aparecimento de sintomas de deficiência de boro. Na Tabela 13 pode-se observar que o uso de diferentes fontes de boro, contendo ou não cálcio em sua composição, não influenciaram significativamente a relação $\mathrm{Ca}: \mathrm{B}$, o que é resultado da maior influência do cálcio adicionado pelo uso do termofosfato magnesiano em todas as fontes de boro testadas e pelo fornecimento através da calagem.

Tabela 13. Relação Ca:B foliar, nos diferentes tratamentos utilizados

\begin{tabular}{lcccc}
\hline Fonte & \multicolumn{4}{c}{ Dose B $\left(\mathrm{kg} \mathrm{ha}^{-1}\right)$} \\
& 1 & 2 & 3 & 4 \\
\hline Ulexita- pó & $264,2 \mathrm{a}$ & $211,7 \mathrm{a}$ & $146,7 \mathrm{a}$ & $139,2 \mathrm{a}$ \\
Colemanita- pó & $294,7 \mathrm{a}$ & $180,7 \mathrm{a}$ & $203,0 \mathrm{a}$ & $160,0 \mathrm{a}$ \\
Ulexita- gran. & $301,7 \mathrm{a}$ & $229,2 \mathrm{a}$ & $201,0 \mathrm{a}$ & $195,2 \mathrm{a}$ \\
Termofosfato-B & $353,7 \mathrm{a}$ & $362,5 \mathrm{a}$ & $306,2 \mathrm{a}$ & $312,5 \mathrm{a}$ \\
Ácido bórico & $249,2 \mathrm{a}$ & $163,5 \mathrm{a}$ & $145,0 \mathrm{a}$ & $128,2 \mathrm{a}$ \\
\hline
\end{tabular}

Médias de quatro repetições seguidas de mesma letra na coluna não diferem entre si pelo teste de Tukey a 5\% de significância

Na Figura 3 observa-se diminuição significativa $(p>0,01)$ e linear da relação $\mathrm{Ca}$ :B foliar com o aumento das doses de boro testadas, confirmando a eficiência no fornecimento de boro em todas as fontes e doses avaliadas. 


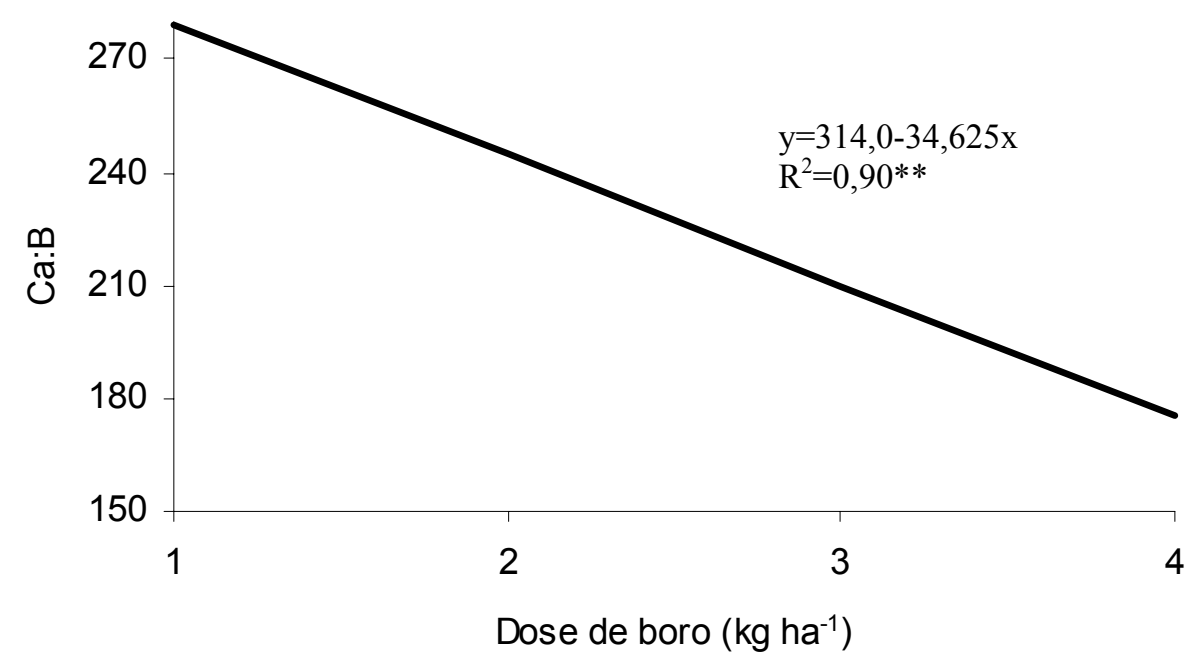

Figura 3- Correlação entre doses de boro aplicadas no solo e as relações foliares

\subsection{Avaliação de atributos químicos do solo}

A Tabela 14 apresenta o efeito dos tratamentos nos teores no solo de fósforo $(\mathrm{P})$, cálcio $(\mathrm{Ca})$, magnésio $(\mathrm{Mg})$, boro $(\mathrm{B})$, bem como a influência na saturação por bases $(\mathrm{V} \%$ ), para a profundidade de amostragem de $0-20 \mathrm{~cm}$. Verifica-se que não houve diferença estatística significativa para $\mathrm{P}, \mathrm{Ca}$ e V\%.

Pode-se observar diferença significativa para $\mathrm{Mg}$ e $\mathrm{B}$. O maior teor de magnésio é observado em T20 (ácido bórico, $4 \mathrm{~kg} \mathrm{~B} \mathrm{ha}^{-1}+$ termofosfato magnesiano, $1000 \mathrm{~kg} \mathrm{ha}^{-1}$ ) e o menor teor em T2 (ulexita-pó, $2 \mathrm{~kg} \mathrm{~B} \mathrm{ha}^{-1}+$ termofosfato magnesiano, $500 \mathrm{~kg} \mathrm{ha}^{-1}$ ). Em relação aos teores de boro no solo observa-se nos tratamentos T16 (termofosfato com B, $4 \mathrm{~kg} \mathrm{~B} \mathrm{ha}^{-1}$ ) e T8 (colemanita, $4 \mathrm{~kg} \mathrm{~B} \mathrm{ha}^{-1}+$ termofosfato magnesiano, $1000 \mathrm{~kg}$ $\mathrm{ha}^{-1}$ ) os maiores valores após onze meses da aplicação dos tratamentos, confirmando o citado por Byers et al. (2001) que fontes de boro menos solúveis permitem a manutenção de maiores teores de boro no solo, principalmente em condições de solos arenosos. Os tratamentos que não receberam boro (termofosfato magnesiano e testemunha) foram os que apresentaram os menores valores deste nutriente no solo, aliado ao fato de todos os 
tratamentos apresentarem altos valores de saturação por bases (V\%), condição esta favorável a maior lixiviação do elemento, pelo aumento de cargas negativas dependentes de $\mathrm{pH}$.

Tabela 14. Atributos químicos do solo amostrado onze meses após aplicação dos tratamentos na profundidade de $0-20 \mathrm{~cm}$

\begin{tabular}{|c|c|c|c|c|c|}
\hline \multirow[t]{2}{*}{ Tratamento } & $\mathrm{P}$ & $\mathrm{Ca}$ & $\mathrm{Mg}$ & \multirow{2}{*}{$\begin{array}{c}\text { B } \\
\text {----mg dm}{ }^{-3}---\end{array}$} & \multirow{2}{*}{$\begin{array}{c}\mathrm{V} \\
-----\%----\end{array}$} \\
\hline & $---\mathrm{mg} \mathrm{dm}^{-3}---$ & \multicolumn{2}{|c|}{$---\mathrm{mmol}_{\mathrm{c}} \mathrm{dm}^{-3}$} & & \\
\hline T1 & $62 \mathrm{a}$ & $42,2 \mathrm{a}$ & $22,2 \mathrm{ab}$ & $0,8 \mathrm{ab}$ & $75,5 \mathrm{a}$ \\
\hline $\mathrm{T} 2$ & $62 \mathrm{a}$ & $28,7 \mathrm{a}$ & $13,0 \mathrm{~b}$ & $0,8 \mathrm{ab}$ & $68,7 \mathrm{a}$ \\
\hline $\mathrm{T} 3$ & $63 a$ & $46,0 \mathrm{a}$ & $26,0 \mathrm{ab}$ & $0,8 \mathrm{ab}$ & $77,5 \mathrm{a}$ \\
\hline $\mathrm{T} 4$ & $128 \mathrm{a}$ & $56,6 \mathrm{a}$ & $36,2 \mathrm{ab}$ & $1,0 \mathrm{ab}$ & $80,7 \mathrm{a}$ \\
\hline T5 & $73 a$ & $59,7 \mathrm{a}$ & $25,0 \mathrm{ab}$ & $0,6 \mathrm{ab}$ & $84,2 \mathrm{a}$ \\
\hline T6 & $56 a$ & $37,7 \mathrm{a}$ & $19,7 \mathrm{ab}$ & $0,9 \mathrm{ab}$ & $73,2 \mathrm{a}$ \\
\hline $\mathrm{T} 7$ & $96 \mathrm{a}$ & $48,0 \mathrm{a}$ & $24,5 \mathrm{ab}$ & $0,9 \mathrm{ab}$ & $77,5 \mathrm{a}$ \\
\hline $\mathrm{T} 8$ & $108 \mathrm{a}$ & $49,7 \mathrm{a}$ & $31,7 \mathrm{ab}$ & $1,0 \mathrm{a}$ & $79,7 \mathrm{a}$ \\
\hline T9 & $45 \mathrm{a}$ & $38,7 \mathrm{a}$ & $22,2 \mathrm{ab}$ & $0,7 \mathrm{ab}$ & $73,7 \mathrm{a}$ \\
\hline $\mathrm{T} 10$ & $55 \mathrm{a}$ & $36,0 \mathrm{a}$ & $18,2 \mathrm{ab}$ & $0,8 \mathrm{ab}$ & $72,5 \mathrm{a}$ \\
\hline $\mathrm{T} 11$ & $74 a$ & $41,5 \mathrm{a}$ & $24,2 \mathrm{ab}$ & $0,9 \mathrm{ab}$ & $72,2 \mathrm{a}$ \\
\hline $\mathrm{T} 12$ & $78 \mathrm{a}$ & $54,5 \mathrm{a}$ & $27,5 \mathrm{ab}$ & $0,7 \mathrm{ab}$ & $82,0 \mathrm{a}$ \\
\hline $\mathrm{T} 13$ & $56 a$ & $39,7 \mathrm{a}$ & $17,7 \mathrm{ab}$ & $0,6 \mathrm{ab}$ & $76,0 \mathrm{a}$ \\
\hline T14 & $49 a$ & $37,7 \mathrm{a}$ & $15,5 \mathrm{ab}$ & $0,8 \mathrm{ab}$ & $74,7 \mathrm{a}$ \\
\hline $\mathrm{T} 15$ & $59 a$ & $46,2 \mathrm{a}$ & $28,7 \mathrm{ab}$ & $0,7 \mathrm{ab}$ & $78,5 \mathrm{a}$ \\
\hline T16 & $61 \mathrm{a}$ & $34,2 \mathrm{a}$ & $21,2 \mathrm{ab}$ & $1,0 \mathrm{a}$ & $73,7 \mathrm{a}$ \\
\hline T17 & $60 \mathrm{a}$ & $40,5 \mathrm{a}$ & $26,7 \mathrm{ab}$ & $0,8 \mathrm{ab}$ & $74,2 \mathrm{a}$ \\
\hline T18 & $82 a$ & $46,5 \mathrm{a}$ & $34,0 \mathrm{ab}$ & $0,9 \mathrm{ab}$ & $79,2 \mathrm{a}$ \\
\hline T19 & $68 \mathrm{a}$ & $35,5 \mathrm{a}$ & $19,5 \mathrm{ab}$ & $0,9 \mathrm{ab}$ & $73,5 \mathrm{a}$ \\
\hline $\mathrm{T} 20$ & $102 a$ & $72,0 \mathrm{a}$ & $48,7 \mathrm{a}$ & $0,8 \mathrm{ab}$ & $85,0 \mathrm{a}$ \\
\hline $\mathrm{T} 21$ & $74 a$ & $44,7 \mathrm{a}$ & $21,5 \mathrm{ab}$ & $0,6 \mathrm{ab}$ & $77,2 \mathrm{a}$ \\
\hline $\mathrm{T} 22$ & $61 \mathrm{a}$ & $46,5 \mathrm{a}$ & $23,2 \mathrm{ab}$ & $0,6 \mathrm{ab}$ & $75,7 \mathrm{a}$ \\
\hline $\mathrm{T} 23$ & $67 a$ & $51,1 \mathrm{a}$ & $25,5 \mathrm{ab}$ & $0,7 \mathrm{ab}$ & $75,5 \mathrm{a}$ \\
\hline $\mathrm{T} 24$ & $77 \mathrm{a}$ & $49,7 \mathrm{a}$ & $20,2 \mathrm{ab}$ & $0,5 b$ & $80,0 \mathrm{a}$ \\
\hline $\mathrm{T} 25$ & $51 \mathrm{a}$ & $38,0 \mathrm{a}$ & $16,7 \mathrm{ab}$ & $0,6 a b$ & $75,2 \mathrm{a}$ \\
\hline Valor F & $1,5 \mathrm{~ns}$ & $1,0 \mathrm{~ns}$ & $1,3^{*}$ & $2,0^{*}$ & $0,7 \mathrm{~ns}$ \\
\hline CV (\%) & 46,4 & 40,6 & 54,4 & 26,2 & 12,4 \\
\hline DMS & 88,1 & 49,0 & 35,6 & 0,5 & 25,6 \\
\hline
\end{tabular}

Médias de quatro repetições contidas em colunas, seguidas de mesma letra não diferem entre si pelo teste de Tukey. * e **: nível de significância de 5\% e 1\% respectivamente. ns: não significativo 
Avaliando-se os efeitos apenas dos tratamentos compostos pelas fontes de boro observa-se não haver efeito estatístico significativo das fontes utilizadas nos teores no solo de fósforo (Tabela 15), magnésio (Tabela 16), cálcio (Tabela 17), boro (Tabela 19), bem como no valor da saturação por bases (Tabela 18). Em relação os teores de $\mathrm{P}$ e $\mathrm{Mg}$, esperava-se não haver diferença entre as fontes, uma vez que todas receberam as mesmas doses de termofosfato magnesiano, incluindo portanto $\mathrm{P}$ e $\mathrm{Mg}$.

Tabela 15. Teores de fósforo no solo, em $\mathrm{mg} \mathrm{dm}^{-3}$, nas diferentes fontes e doses de boro utilizadas

\begin{tabular}{lcccc}
\hline Fonte & \multicolumn{4}{c}{ Doses B $\left(\mathrm{kg} \mathrm{ha}^{-1}\right)$} \\
\\
\hline Ulexita- pó & 1 & 2 & 3 & 4 \\
Colemanita- pó & $62 \mathrm{a}$ & $62 \mathrm{a}$ & $63 \mathrm{a}$ & $128 \mathrm{a}$ \\
Ulexita- gran. & $73 \mathrm{a}$ & $56 \mathrm{a}$ & $96 \mathrm{a}$ & $108 \mathrm{a}$ \\
Termofosfato-B & $45 \mathrm{a}$ & $55 \mathrm{a}$ & $74 \mathrm{a}$ & $78 \mathrm{a}$ \\
Ácido bórico & $56 \mathrm{a}$ & $49 \mathrm{a}$ & $59 \mathrm{a}$ & $61 \mathrm{a}$ \\
\hline
\end{tabular}

Médias de quatro repetições seguidas de mesma letra na coluna não diferem entre si pelo teste de Tukey a 5\% de significância

Tabela 16. Teores de magnésio no solo, em $\mathrm{mmol}_{\mathrm{c}} \mathrm{dm}^{-3}$, nas diferentes fontes e doses de boro utilizadas

\begin{tabular}{lcccc}
\hline Fonte & \multicolumn{4}{c}{ Doses B $\left(\mathrm{kg} \mathrm{ha}^{-1}\right)$} \\
& 1 & 2 & 3 & 4 \\
\hline Ulexita- pó & $22,2 \mathrm{a}$ & $13,0 \mathrm{a}$ & $26,0 \mathrm{a}$ & $36,2 \mathrm{a}$ \\
Colemanita- pó & $25,0 \mathrm{a}$ & $19,7 \mathrm{a}$ & $24,5 \mathrm{a}$ & $31,7 \mathrm{a}$ \\
Ulexita- gran. & $22,2 \mathrm{a}$ & $18,2 \mathrm{a}$ & $24,2 \mathrm{a}$ & $27,5 \mathrm{a}$ \\
Termofosfato-B & $17,7 \mathrm{a}$ & $15,5 \mathrm{a}$ & $28,7 \mathrm{a}$ & $21,2 \mathrm{a}$ \\
Ácido bórico & $26,7 \mathrm{a}$ & $34,0 \mathrm{a}$ & $19,5 \mathrm{a}$ & $48,7 \mathrm{a}$ \\
\hline
\end{tabular}

Médias de quatro repetições seguidas de mesma letra na coluna não diferem entre si pelo teste de Tukey a 5\% de significância

$\mathrm{Na}$ Figura 4 pode-se observar que o teor de $\mathrm{P}$ aumentou significativamente ( $\mathrm{p}>0,01)$ e de forma linear com as doses de boro aplicadas no solo, resultado do 
aumento crescente da dose de fósforo adicionada conjuntamente a fonte de boro. $\mathrm{O}$ mesmo ocorre para o magnésio (Figura 5).

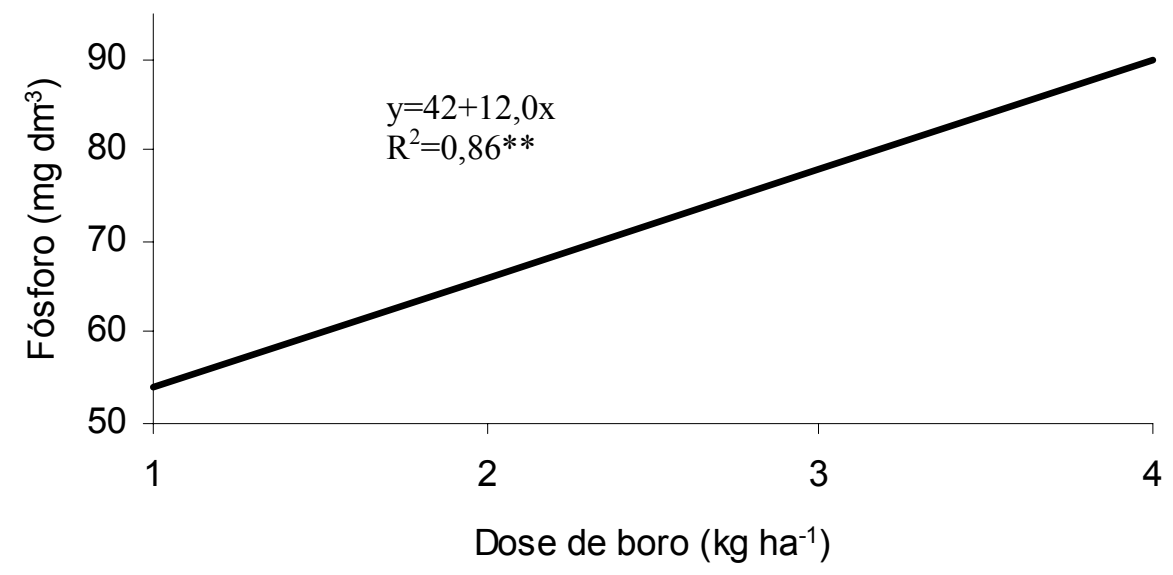

Figura 4- Correlação entre as doses de boro e teores de fósforo no solo

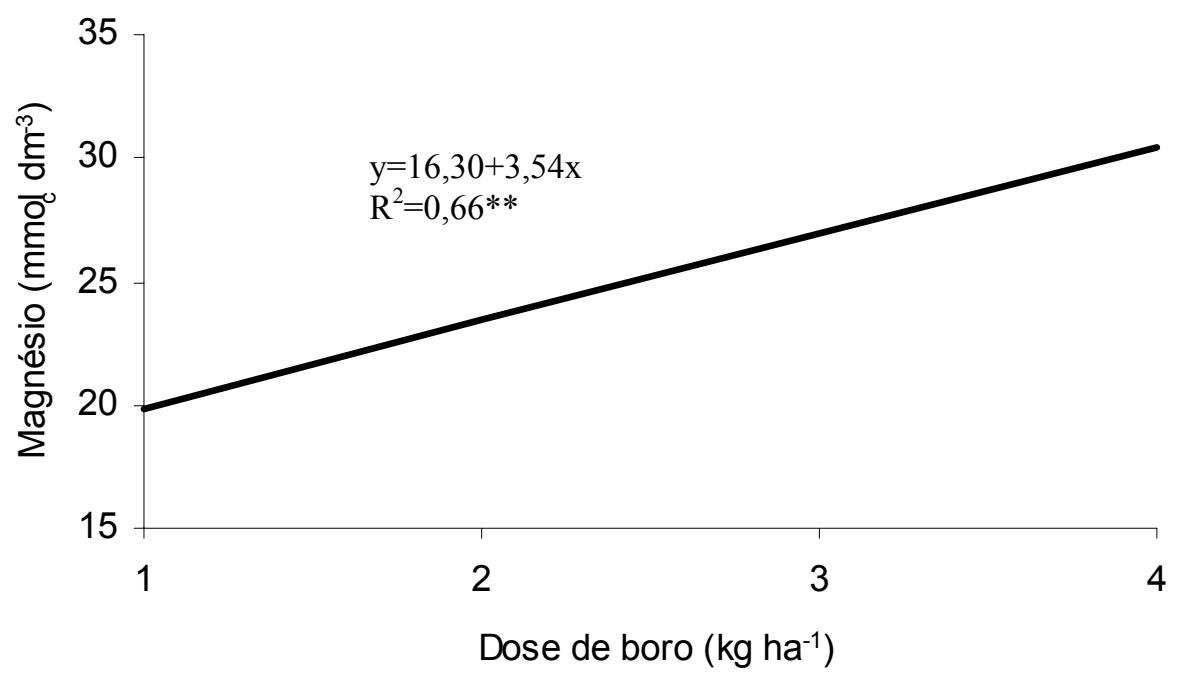

Figura 5- Correlação entre as doses de boro e teores de magnésio no solo 
O teor de cálcio (Tabela 17) e o valor da saturação por bases (Tabela 18) apresentam comportamentos semelhantes, uma vez que o cálcio é um dos componentes da soma de bases (SB). A não ocorrência de diferença significativa entre as fontes de boro nos teores de cálcio mostra que as fontes de boro que contém cálcio na composição não influenciaram os teores deste elemento no solo.

Tabela 17. Teores de cálcio no solo, em $\mathrm{mmol}_{\mathrm{c}} \mathrm{dm}^{-3}$, nas diferentes fontes e doses de boro utilizadas

\begin{tabular}{lcccc}
\hline Fonte & \multicolumn{4}{c}{ Doses B $\left(\mathrm{kg} \mathrm{ha}^{-1}\right)$} \\
& 1 & 2 & 3 & 4 \\
\hline Ulexita- pó & $42,2 \mathrm{a}$ & $28,7 \mathrm{a}$ & $46,0 \mathrm{a}$ & $56,5 \mathrm{a}$ \\
Colemanita- pó & $59,7 \mathrm{a}$ & $37,7 \mathrm{a}$ & $48,0 \mathrm{a}$ & $49,7 \mathrm{a}$ \\
Ulexita- gran. & $38,7 \mathrm{a}$ & $36,0 \mathrm{a}$ & $41,5 \mathrm{a}$ & $54,5 \mathrm{a}$ \\
Termofosfato-B & $39,7 \mathrm{a}$ & $37,7 \mathrm{a}$ & $46,2 \mathrm{a}$ & $34,2 \mathrm{a}$ \\
Ácido bórico & $40,5 \mathrm{a}$ & $46,5 \mathrm{a}$ & $35,5 \mathrm{a}$ & $72,0 \mathrm{a}$ \\
\hline
\end{tabular}

Médias de quatro repetições seguidas de mesma letra na coluna não diferem entre si

pelo teste de Tukey a 5\% de significância

Tabela 18. Valores de saturação por bases, em porcentagem, nas diferentes fontes e doses de boro utilizadas

\begin{tabular}{lcccc}
\hline Fonte & \multicolumn{4}{c}{ Doses B $\left(\mathrm{kg} \mathrm{ha}^{-1}\right)$} \\
& 1 & 2 & 3 & 4 \\
\hline Ulexita- pó & $75,5 \mathrm{a}$ & $68,7 \mathrm{a}$ & $77,5 \mathrm{a}$ & $80,7 \mathrm{a}$ \\
Colemanita- pó & $84,2 \mathrm{a}$ & $73,2 \mathrm{a}$ & $77,5 \mathrm{a}$ & $79,7 \mathrm{a}$ \\
Ulexita- gran. & $73,7 \mathrm{a}$ & $72,5 \mathrm{a}$ & $72,2 \mathrm{a}$ & $82,0 \mathrm{a}$ \\
Termofosfato-B & $76,0 \mathrm{a}$ & $74,7 \mathrm{a}$ & $78,5 \mathrm{a}$ & $73,7 \mathrm{a}$ \\
Ácido bórico & $74,2 \mathrm{a}$ & $79,2 \mathrm{a}$ & $73,5 \mathrm{a}$ & $85,0 \mathrm{a}$ \\
\hline
\end{tabular}

Médias de quatro repetições seguidas de mesma letra na coluna não diferem entre si pelo teste de Tukey a 5\% de significância

$\mathrm{Na}$ Figura 6 pode-se observar aumento significativo $(\mathrm{p}>0,05)$ no teor de cálcio com o aumento das doses de boro aplicadas, esta resposta deve-se ao aumento das doses 
de termofosfato magnesiano aplicado conjuntamente ao boro, não havendo influência do cálcio contido nas fontes que o possuem (ex.: ulexita e colemanita). O mesmo ocorre para a V\% (Figura 7).

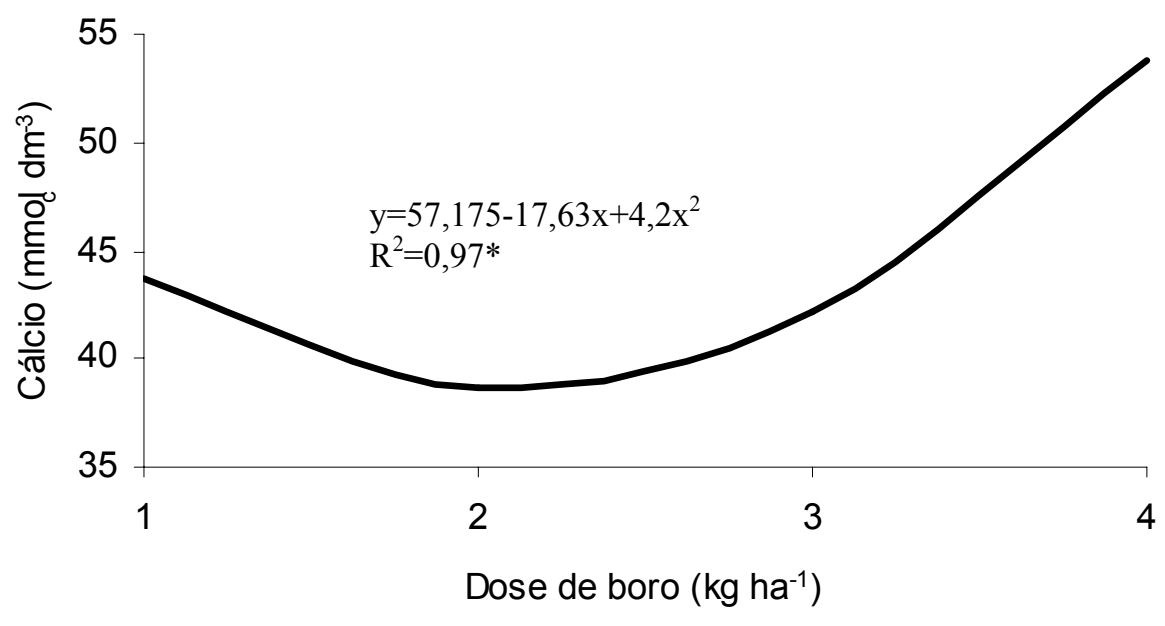

Figura 6- Correlação entre as doses de boro e teores de cálcio no solo

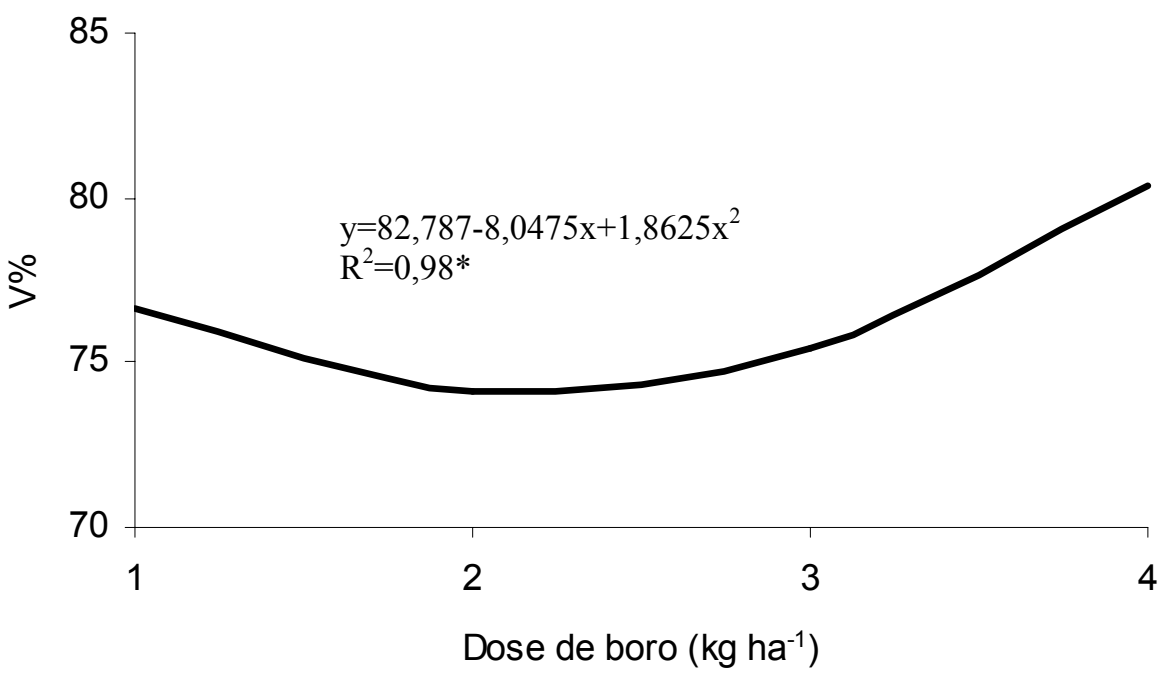

Figura 7- Correlação entre doses de boro aplicadas no solo e a saturação por bases 
Apesar de não ter ocorrido diferença significativa quanto aos teores de boro no solo de acordo com a fonte utilizada (Tabela 19), observa-se tendência de maiores valores deste nutriente para fontes menos solúveis (ex.: colemanita e termofosfato), ou seja, fontes que apresentam maiores teores de boro no solo, extraído por água quente, por um maior período de tempo, sugerindo menor ocorrência de lixiviação do nutriente, conforme citado por Byers et al. (2001).

Tabela 19. Teores de boro no solo, em $\mathrm{mg} \mathrm{dm}^{-3}$ (extrator $\mathrm{H}_{2} \mathrm{O}$ quente), nas diferentes fontes e doses de boro utilizadas

\begin{tabular}{lcccc}
\hline Fonte & \multicolumn{4}{c}{ Doses B $\left(\mathrm{kg} \mathrm{ha}^{-1}\right)$} \\
& 1 & 2 & 3 & 4 \\
\hline Ulexita- pó & $0,77 \mathrm{a}$ & $0,78 \mathrm{a}$ & $0,81 \mathrm{a}$ & $0,96 \mathrm{a}$ \\
Colemanita- pó & $0,65 \mathrm{a}$ & $0,95 \mathrm{a}$ & $0,94 \mathrm{a}$ & $1,02 \mathrm{a}$ \\
Ulexita- gran. & $0,66 \mathrm{a}$ & $0,80 \mathrm{a}$ & $0,90 \mathrm{a}$ & $0,74 \mathrm{a}$ \\
Termofosfato-B & $0,65 \mathrm{a}$ & $0,78 \mathrm{a}$ & $0,76 \mathrm{a}$ & $1,03 \mathrm{a}$ \\
Ácido bórico & $0,76 \mathrm{a}$ & $0,90 \mathrm{a}$ & $0,88 \mathrm{a}$ & $0,81 \mathrm{a}$ \\
\hline
\end{tabular}

Médias de quatro repetições seguidas de mesma letra na coluna não diferem entre si pelo teste de Tukey a 5\% de significância

Quanto aos teores de boro no solo em termos de padrões de fertilidade observa-se que os mesmos estão na classe alta, ou seja, maiores que $0,6 \mathrm{mg} \mathrm{dm}^{-3}$ (GPACC, 1994). Na Figura 8 pode-se observar aumento significativo $(p>0,01)$ e linear no teor de boro do solo com o aumento das doses aplicadas, porém aumento este não proporcional as doses aplicadas, uma vez que para elevação de $1 \mathrm{mg} \mathrm{dm}^{-3}$ de boro na análise de solo na profundidade de 0-20 $\mathrm{cm}$ e considerando a densidade do solo de 1,0, necessitaria da aplicação de $2 \mathrm{~kg} \mathrm{ha}^{-1}$ de B desde que não ocorresse "perdas” no sistema. 


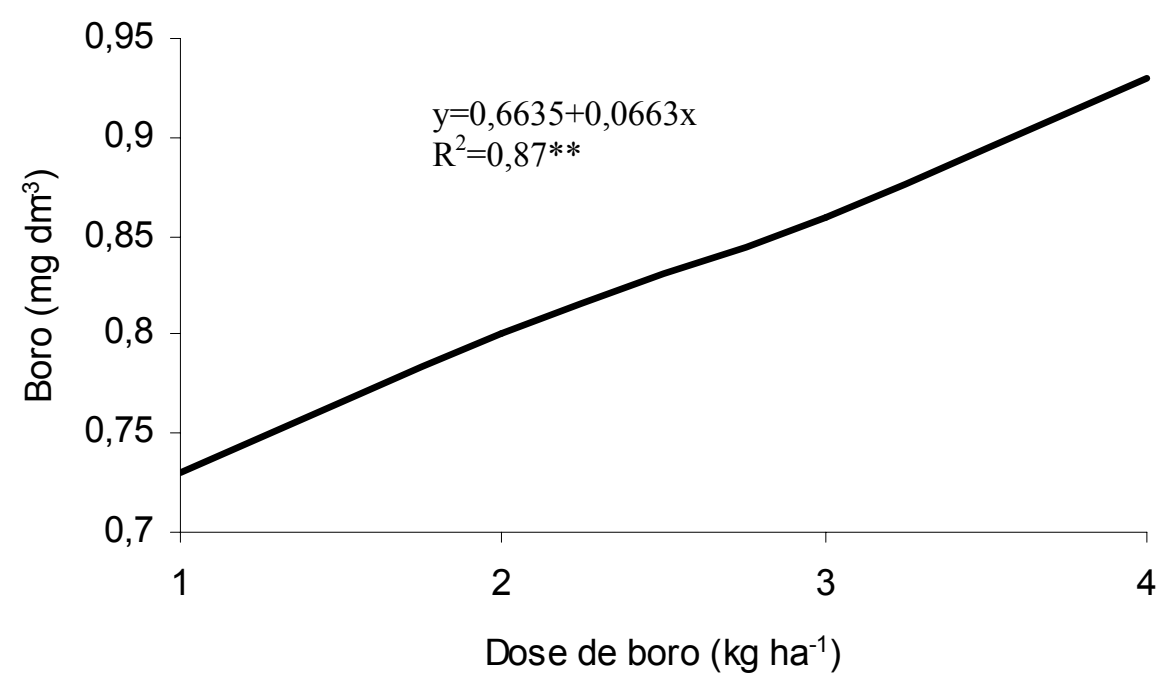

Figura 8- Correlação entre doses de boro aplicadas e teores de boro no solo

\subsection{Avaliação da produtividade de citros}

$\mathrm{Na}$ Tabela 20 está apresentada a produtividade obtida em função dos tratamentos aplicados. Analisando os dados, verifica-se que não houve diferença estatística significativa dos tratamentos na produção dos citros. 
Tabela 20. Produção de citros $\left(\mathrm{t} \mathrm{ha}^{-1}\right.$ e caixas $\left.\mathrm{ha}^{-1}\right)$ obtida para cada tratamento

\begin{tabular}{|c|c|c|}
\hline \multirow[t]{2}{*}{ Tratamento } & \multicolumn{2}{|c|}{ Produção } \\
\hline & $\mathrm{t} \mathrm{ha}^{-1}$ & $\mathrm{cx} \mathrm{ha}^{-1}$ \\
\hline T1- Ulexita pó (1 kg B ha $\left.{ }^{-1}\right)$ & $40,4 a$ & $990 \mathrm{a}$ \\
\hline T2- Ulexita pó (2kg B ha $\left.{ }^{-1}\right)$ & $42,0 \mathrm{a}$ & $1029 a$ \\
\hline T3- Ulexita pó (3kg B ha $\left.{ }^{-1}\right)$ & $39,7 a$ & $973 a$ \\
\hline T4- Ulexita pó (4kg B ha $\left.{ }^{-1}\right)$ & $34,1 \mathrm{a}$ & $836 a$ \\
\hline T5- Colemanita pó (1kg B ha $\left.{ }^{-1}\right)$ & $36,3 a$ & $890 \mathrm{a}$ \\
\hline T6- Colemanita pó (2kg B ha $\left.{ }^{-1}\right)$ & $47,7 \mathrm{a}$ & $1169 a$ \\
\hline T7- Colemanita pó ( $\left.3 \mathrm{~kg} \mathrm{~B} \mathrm{ha}{ }^{-1}\right)$ & $43,5 \mathrm{a}$ & $1066 a$ \\
\hline T8- Colemanita pó (4kg B ha') & $43,5 \mathrm{a}$ & $1066 \mathrm{a}$ \\
\hline T9- Ulexita gran. (1 kg B ha-1) & $40,2 \mathrm{a}$ & $985 a$ \\
\hline T10- Ulexita gran. $(2 \mathrm{~kg} \mathrm{~B} \mathrm{ha-1})$ & $44,8 \mathrm{a}$ & $1098 \mathrm{a}$ \\
\hline T11- Ulexita gran. $\left(3 \mathrm{~kg} \mathrm{~B} \mathrm{ha}{ }^{-1}\right)$ & $37,3 \mathrm{a}$ & $914 \mathrm{a}$ \\
\hline T12- Ulexita gran. (4kg B ha ${ }^{-1}$ ) & $38,3 \mathrm{a}$ & $939 a$ \\
\hline T13- Termofosfato-B (1 $\left.\mathrm{kg} \mathrm{B} \mathrm{ha}^{-1}\right)$ & $46,4 \mathrm{a}$ & $1137 \mathrm{a}$ \\
\hline T14- Termofosfato-B $\left(2 \mathrm{~kg} \mathrm{~B} \mathrm{ha}^{-1}\right)$ & $47,0 \mathrm{a}$ & $1152 \mathrm{a}$ \\
\hline T15- Termofosfato-B $\left(3 \mathrm{~kg} \mathrm{~B} \mathrm{ha}^{-1}\right)$ & $34,9 \mathrm{a}$ & $855 a$ \\
\hline T16- Termofosfato-B $\left(4 \mathrm{~kg} \mathrm{~B} \mathrm{ha}^{-1}\right)$ & $34,2 \mathrm{a}$ & $838 \mathrm{a}$ \\
\hline T17- Ácido bórico (1kg B ha $\left.{ }^{-1}\right)$ & $39,9 a$ & $978 \mathrm{a}$ \\
\hline T18- Ácido bórico (2kg B ha $\left.{ }^{-1}\right)$ & $44,3 \mathrm{a}$ & $1086 a$ \\
\hline T19- Ácido bórico (3kg B ha $\left.{ }^{-1}\right)$ & $42,7 \mathrm{a}$ & $1047 \mathrm{a}$ \\
\hline T20- Ácido bórico (4kg B ha ${ }^{-1}$ ) & $41,7 \mathrm{a}$ & $1022 a$ \\
\hline T21- Termofosfato-Mg $\left(250 \mathrm{~kg} \mathrm{ha}^{-1}\right)$ & $35,9 a$ & $880 \mathrm{a}$ \\
\hline T22- Termofosfato- $\mathrm{Mg}\left(500 \mathrm{~kg} \mathrm{ha}^{-1}\right)$ & $44,2 \mathrm{a}$ & $1083 a$ \\
\hline T23- Termofosfato-Mg $\left(750 \mathrm{~kg} \mathrm{ha}^{-1}\right)$ & $42,8 \mathrm{a}$ & $1049 a$ \\
\hline T24- Termofosfato-Mg $\left(1000 \mathrm{~kg} \mathrm{ha}^{-1}\right)$ & $44,8 \mathrm{a}$ & $1098 \mathrm{a}$ \\
\hline T25- Testemunha & $37,6 \mathrm{a}$ & $922 \mathrm{a}$ \\
\hline Valor F & $0,7 \mathrm{~ns}$ & $0,7 \mathrm{~ns}$ \\
\hline CV $(\%)$ & 23,3 & 23,3 \\
\hline DMS & 25,7 & 25,7 \\
\hline
\end{tabular}

Médias de quatro repetições contidas em colunas, seguidas de mesma letra não diferem entre si pelo teste de Tukey. * e **: nível de significância de 5 e $1 \%$ respectivamente. ns: não significativo

Quanto a produtividade pode-se observar que a mesma encontra-se por volta de $41 \mathrm{t} \mathrm{ha}^{-1}$ e 1004 caixas $\mathrm{ha}^{-1}$, ou seja, considerada alta para condições de sequeiro 
(ANEXO B) na região do sul de Minas Gerais, bem como pela elevada ocorrência da CVC nessa área.

A mesma tendência de não significância ocorre quando analisados apenas os tratamentos com adição de boro. Não observa-se influência estatística significativa das diferentes fontes de boro na produtividade da cultura (Tabela 21). Apesar da não ocorrência de diferença entre as doses de boro e a produção (ANEXO A), observa-se tendência de ocorrência de maiores produções na dose aplicada de $2 \mathrm{~kg}$ de B ha ${ }^{-1}$, o que coincide com a máxima recomendação de adubação boratada para a cultura, lembrando também que essa área vinha recebendo nos anos anteriores à instalação do experimento a aplicação de boro principalmente via herbicida, bem como pulverizações foliares.

Tabela 21. Produção, em toneladas por hectare, obtida para cada fonte e doses de boro utilizadas

\begin{tabular}{lcccc}
\hline Fonte & \multicolumn{4}{c}{ Doses B $\left(\mathrm{kg} \mathrm{ha}^{-1}\right)$} \\
& 1 & 2 & 3 & 4 \\
\hline Ulexita- pó & $40,4 \mathrm{a}$ & $42,0 \mathrm{a}$ & $39,7 \mathrm{a}$ & $34,1 \mathrm{a}$ \\
Colemanita- pó & $36,3 \mathrm{a}$ & $47,7 \mathrm{a}$ & $43,5 \mathrm{a}$ & $43,5 \mathrm{a}$ \\
Ulexita- gran. & $40,2 \mathrm{a}$ & $44,8 \mathrm{a}$ & $37,3 \mathrm{a}$ & $38,3 \mathrm{a}$ \\
Termofosfato-B & $46,4 \mathrm{a}$ & $47,0 \mathrm{a}$ & $34,9 \mathrm{a}$ & $34,2 \mathrm{a}$ \\
Ácido bórico & $39,9 \mathrm{a}$ & $44,3 \mathrm{a}$ & $42,7 \mathrm{a}$ & $41,7 \mathrm{a}$ \\
\hline
\end{tabular}

Médias de quatro repetições seguidas de mesma letra na coluna não diferem entre si pelo teste de Tukey a 5\% de significância

\subsection{Avaliação dos atributos qualitativos dos frutos}

\subsubsection{Atributos tecnológicos dos frutos}

Na Tabela 22 apresenta-se a influência dos tratamentos nos atributos tecnológicos dos frutos. Nesses atributos observa-se diferença significativa apenas no rendimento de suco, expresso em porcentagem. 
Tabela 22. Atributos tecnológicos dos frutos obtidos para cada tratamento

\begin{tabular}{|c|c|c|c|c|}
\hline Tratamento & RATIO & $\begin{array}{c}\text { Sólidos solúveis/caixa } \\
\left(\mathrm{kg} \mathrm{caixa}^{-1}\right)\end{array}$ & $\begin{array}{c}\text { Rendimento suco } \\
(\%)\end{array}$ & ${ }^{\circ} \mathrm{BRIX}$ \\
\hline T1-Ulexita pó $\left(1 \mathrm{kgB} \mathrm{ha}^{-1}\right)$ & $13,2 \mathrm{a}$ & $3,1 \mathrm{a}$ & $61,7 \mathrm{a}$ & $12,5 \mathrm{a}$ \\
\hline T2-Ulexita pó (2kgB ha- $\left.{ }^{-1}\right)$ & $14,2 \mathrm{a}$ & $3,0 \mathrm{a}$ & $60,5 \mathrm{ab}$ & $12,2 \mathrm{a}$ \\
\hline T3-Ulexita pó $\left(3 \mathrm{kgB} \mathrm{ha}^{-1}\right)$ & $13,9 \mathrm{a}$ & $3,0 \mathrm{a}$ & $60,4 a b$ & $12,2 \mathrm{a}$ \\
\hline T4-Ulexita pó $\left(4 \mathrm{kgB} \mathrm{ha}^{-1}\right)$ & $13,8 \mathrm{a}$ & $3,1 \mathrm{a}$ & $61,0 \mathrm{ab}$ & $12,3 \mathrm{a}$ \\
\hline T5-Colemanita pó $\left(1 \mathrm{kgB} \mathrm{ha}{ }^{-1}\right)$ & $15,7 \mathrm{a}$ & $2,9 a$ & $60,5 \mathrm{ab}$ & $11,9 \mathrm{a}$ \\
\hline T6-Colemanita pó $\left(2 \mathrm{kgB} \mathrm{ha}^{-1}\right)$ & $13,3 \mathrm{a}$ & $3,0 \mathrm{a}$ & $63,0 \mathrm{a}$ & $11,8 \mathrm{a}$ \\
\hline T7-Colemanita pó $\left(3 \mathrm{kgB} \mathrm{ha}^{-1}\right)$ & $15,2 \mathrm{a}$ & $3,0 \mathrm{a}$ & $58,9 \mathrm{ab}$ & $12,6 a$ \\
\hline T8-Colemanita pó $\left(4 \mathrm{kgB} \mathrm{ha}^{-1}\right)$ & $13,0 \mathrm{a}$ & $3,1 \mathrm{a}$ & $61,0 \mathrm{ab}$ & $12,4 \mathrm{a}$ \\
\hline T9-Ulexita gran. $\left(1 \mathrm{kgB} \mathrm{ha}^{-1}\right)$ & $15,3 \mathrm{a}$ & $2,9 a$ & $60,7 \mathrm{ab}$ & $11,9 \mathrm{a}$ \\
\hline T10-Ulexita gran. $\left(2 \mathrm{kgB} \mathrm{ha}^{-1}\right)$ & $14,6 \mathrm{a}$ & $3,2 \mathrm{a}$ & $62,7 \mathrm{a}$ & $12,4 \mathrm{a}$ \\
\hline T11-Ulexita gran. $\left(3 \mathrm{kgB} \mathrm{ha}^{-1}\right)$ & $15,9 \mathrm{a}$ & $3,2 \mathrm{a}$ & $61,6 a$ & $12,9 \mathrm{a}$ \\
\hline T12-Ulexita gran. $\left(4 \mathrm{kgB} \mathrm{ha}^{-1}\right)$ & $14,9 \mathrm{a}$ & $2,7 \mathrm{a}$ & $52,0 \mathrm{~b}$ & $12,5 \mathrm{a}$ \\
\hline T13-Termofosfato-B $\left(1 \mathrm{kgB} \mathrm{ha}^{-1}\right)$ & $13,1 \mathrm{a}$ & $3,1 \mathrm{a}$ & $63,3 \mathrm{a}$ & $12,0 \mathrm{a}$ \\
\hline T14-Termofosfato-B $\left(2 \mathrm{kgB} \mathrm{ha}^{-1}\right)$ & $12,8 \mathrm{a}$ & $3,0 \mathrm{a}$ & $60,6 a b$ & $12,0 \mathrm{a}$ \\
\hline T15-Termofosfato-B $\left(3 \mathrm{kgB} \mathrm{ha}^{-1}\right)$ & $13,9 \mathrm{a}$ & $3,2 \mathrm{a}$ & $61,9 \mathrm{a}$ & $12,7 \mathrm{a}$ \\
\hline T16-Termofosfato-B $\left(4 \mathrm{kgB} \mathrm{ha}^{-1}\right)$ & $14,7 \mathrm{a}$ & $3,2 \mathrm{a}$ & $62,1 \mathrm{a}$ & $12,6 \mathrm{a}$ \\
\hline T17-Ácido bórico $\left(1 \mathrm{kgB} \mathrm{ha}^{-1}\right)$ & $15,6 \mathrm{a}$ & $3,1 \mathrm{a}$ & $63,8 \mathrm{a}$ & $11,9 \mathrm{a}$ \\
\hline T18-Ácido bórico $\left(2 \mathrm{kgB} \mathrm{ha}^{-1}\right)$ & $14,2 \mathrm{a}$ & $3,1 \mathrm{a}$ & $62,5 \mathrm{a}$ & $12,3 \mathrm{a}$ \\
\hline T19-Ácido bórico $\left(3 \mathrm{kgB} \mathrm{ha}^{-1}\right)$ & $14,4 \mathrm{a}$ & $3,0 \mathrm{a}$ & $60,2 \mathrm{ab}$ & $12,9 \mathrm{a}$ \\
\hline T20-Ácido bórico $\left(4 \mathrm{kgB} \mathrm{ha}^{-1}\right)$ & $14,3 \mathrm{a}$ & $2,9 a$ & $58,0 \mathrm{ab}$ & $12,2 \mathrm{a}$ \\
\hline T21-Termofosfato-Mg $\left(250 \mathrm{~kg} \mathrm{ha}^{-1}\right)$ & $14,5 \mathrm{a}$ & $3,2 \mathrm{a}$ & $64,1 \mathrm{a}$ & $12,1 \mathrm{a}$ \\
\hline T22-Termofosfato-Mg $\left(500 \mathrm{~kg} \mathrm{ha}^{-1}\right)$ & $13,9 \mathrm{a}$ & $3,0 \mathrm{a}$ & $58,6 a b$ & $12,9 \mathrm{a}$ \\
\hline T23-Termofosfato-Mg $\left(750 \mathrm{~kg} \mathrm{ha}^{-1}\right)$ & $14,9 \mathrm{a}$ & $3,2 \mathrm{a}$ & $62,4 a$ & $12,4 \mathrm{a}$ \\
\hline T24-Termofosfato-Mg $\left(1000 \mathrm{~kg} \mathrm{~h}^{-1}\right)$ & $15,2 \mathrm{a}$ & $3,1 \mathrm{a}$ & $60,5 \mathrm{ab}$ & $12,8 \mathrm{a}$ \\
\hline T25- Testemunha & $14,8 \mathrm{a}$ & $3,0 \mathrm{a}$ & $59,9 \mathrm{ab}$ & $12,4 \mathrm{a}$ \\
\hline Valor F & $0,9 \mathrm{~ns}$ & $0,8 \mathrm{~ns}$ & $1,9 *$ & $0,4 \mathrm{~ns}$ \\
\hline CV (\%) & 12,5 & 8,7 & 5,7 & 8,3 \\
\hline DMS & 4,8 & 0,7 & 9,3 & 2,7 \\
\hline
\end{tabular}

Médias de quatro repetições contidas em colunas, seguidas de mesma letra não diferem entre si pelo teste de Tukey. * e **: nível de significância de 5 e 1\% respectivamente. ns: não significativo

Na Tabela 23 pode-se observar a influência das fontes de boro no RATIO, o qual expressa a relação de sólidos solúveis, medido através do ${ }^{\circ}$ BRIX, com a acidez do suco. Nota-se que as fontes não influenciaram os valores de RATIO, sendo que o aumento da dose de boro também não proporcionou diferença estatística significativa (ANEXO A). 
Tabela 23. Valor de RATIO obtido para cada fonte e doses de boro utilizadas

\begin{tabular}{lcccc}
\hline Fonte & \multicolumn{4}{c}{ Doses B $\left(\mathrm{kg} \mathrm{ha}^{-1}\right)$} \\
\\
\hline Ulexita- pó & 1 & 2 & 3 & 4 \\
Colemanita- pó & $13,2 \mathrm{a}$ & $14,2 \mathrm{a}$ & $13,9 \mathrm{a}$ & $13,8 \mathrm{a}$ \\
Ulexita- gran. & $15,7 \mathrm{a}$ & $13,3 \mathrm{a}$ & $15,2 \mathrm{a}$ & $13,0 \mathrm{a}$ \\
Termofosfato-B & $15,3 \mathrm{a}$ & $14,6 \mathrm{a}$ & $15,9 \mathrm{a}$ & $14,9 \mathrm{a}$ \\
Ácido bórico & $13,1 \mathrm{a}$ & $12,8 \mathrm{a}$ & $13,9 \mathrm{a}$ & $14,7 \mathrm{a}$ \\
\hline
\end{tabular}

Médias de quatro repetições seguidas de mesma letra na coluna não diferem entre si pelo teste de Tukey a 5\% de significância

A mesma tendência pode ser observada para o teor de sólidos solúveis (Tabela 24) e o ${ }^{\circ}$ BRIX (Tabela 25). O boro entretanto, dentre suas funções, participa da translocação de açucares e carboidratos através da habilidade que possui de ligar-se a estes compostos formando complexos que atravessam mais facilmente as membranas celulares (Shelp,1993), portanto esperava-se que maiores doses de boro contribuíssem para maior acúmulo de açúcares nos frutos. O mesmo foi observado por Cabrita (1993), onde maiores aplicações de boro no solo não influenciaram as características tecnológicas dos frutos.

Tabela 24. Teor de sólidos solúveis, expresso em $\mathrm{kg}$ por caixa $(40,8 \mathrm{~kg})$, obtido para cada fonte e doses de boro utilizadas

\begin{tabular}{lcccc}
\hline Fonte & \multicolumn{4}{c}{ Doses B $\left(\mathrm{kg} \mathrm{ha}^{-1}\right)$} \\
& 1 & 2 & 3 & 4 \\
\hline Ulexita- pó & $3,1 \mathrm{a}$ & $3,0 \mathrm{a}$ & $3,0 \mathrm{a}$ & $3,1 \mathrm{a}$ \\
Colemanita- pó & $2,9 \mathrm{a}$ & $3,0 \mathrm{a}$ & $3,0 \mathrm{a}$ & $3,1 \mathrm{a}$ \\
Ulexita- gran. & $2,9 \mathrm{a}$ & $3,2 \mathrm{a}$ & $3,2 \mathrm{a}$ & $2,7 \mathrm{a}$ \\
Termofosfato-B & $3,1 \mathrm{a}$ & $3,0 \mathrm{a}$ & $3,2 \mathrm{a}$ & $3,2 \mathrm{a}$ \\
Ácido bórico & $3,1 \mathrm{a}$ & $3,1 \mathrm{a}$ & $3,0 \mathrm{a}$ & $2,9 \mathrm{a}$ \\
\hline
\end{tabular}

Médias de quatro repetições seguidas de mesma letra na coluna não diferem entre si pelo teste de Tukey a 5\% de significância 
Tabela 25. Valor de ${ }^{\circ}$ BRIX obtido para cada fonte e doses de boro utilizadas

\begin{tabular}{lcccc}
\hline Fonte & \multicolumn{4}{c}{ Dose B $\left(\mathrm{kg} \mathrm{ha}^{-1}\right)$} \\
& 1 & 2 & 3 & 4 \\
\hline Ulexita- pó & $12,5 \mathrm{a}$ & $12,2 \mathrm{a}$ & $12,2 \mathrm{a}$ & $12,3 \mathrm{a}$ \\
Colemanita- pó & $11,9 \mathrm{a}$ & $11,8 \mathrm{a}$ & $12,6 \mathrm{a}$ & $12,4 \mathrm{a}$ \\
Ulexita- gran. & $11,9 \mathrm{a}$ & $12,4 \mathrm{a}$ & $12,9 \mathrm{a}$ & $12,5 \mathrm{a}$ \\
Termofosfato-B & $12,0 \mathrm{a}$ & $12,0 \mathrm{a}$ & $12,7 \mathrm{a}$ & $12,6 \mathrm{a}$ \\
Ácido bórico & $11,9 \mathrm{a}$ & $12,3 \mathrm{a}$ & $12,9 \mathrm{a}$ & $12,2 \mathrm{a}$ \\
\hline
\end{tabular}

Médias de quatro repetições seguidas de mesma letra na coluna não diferem entre si pelo teste de Tukey a 5\% de significância

O único parâmetro influenciado pelas doses de boro foi o rendimento de suco (Figura 9). Observa-se que com o aumento da dose de boro aplicada houve diminuição linear significativa $(p>0,01)$ no rendimento de suco, o que talvez possa ser explicado pela característica que o elemento possui em participar do metabolismo ou incorporação do cálcio na parede celular (Yamauchi et al., 1986), auxiliando a deposição do mesmo na formação dos pectatos. Desta forma o boro "ajudou" a formar maiores quantidades de tecido, ou seja, bagaço, aumentando a participação desta variável na relação peso suco/peso fruto. Na Tabela 26 observa-se não haver influencia das fontes no parâmetro avaliado.

Tabela 26. Rendimento do suco, expresso em porcentagem, obtido para cada fonte e doses de boro utilizadas

\begin{tabular}{lcccc}
\hline Fonte & \multicolumn{4}{c}{ Doses B $\left(\mathrm{kg} \mathrm{ha}^{-1}\right)$} \\
& 1 & 2 & 3 & 4 \\
\hline Ulexita- pó & $61,7 \mathrm{a}$ & $60,5 \mathrm{a}$ & $60,3 \mathrm{a}$ & $61,0 \mathrm{a}$ \\
Colemanita- pó & $60,6 \mathrm{a}$ & $62,9 \mathrm{a}$ & $58,9 \mathrm{a}$ & $61,0 \mathrm{a}$ \\
Ulexita- gran. & $60,7 \mathrm{a}$ & $62,7 \mathrm{a}$ & $61,6 \mathrm{a}$ & $52,0 \mathrm{a}$ \\
Termofosfato-B & $63,3 \mathrm{a}$ & $60,6 \mathrm{a}$ & $61,9 \mathrm{a}$ & $62,1 \mathrm{a}$ \\
Ácido bórico & $63,8 \mathrm{a}$ & $62,5 \mathrm{a}$ & $60,2 \mathrm{a}$ & $58,0 \mathrm{a}$ \\
\hline Médias de quatro repetições seguidas de mesma letra na coluna não diferem entre si \\
pelo teste de Tukey a 5\% de significância
\end{tabular}




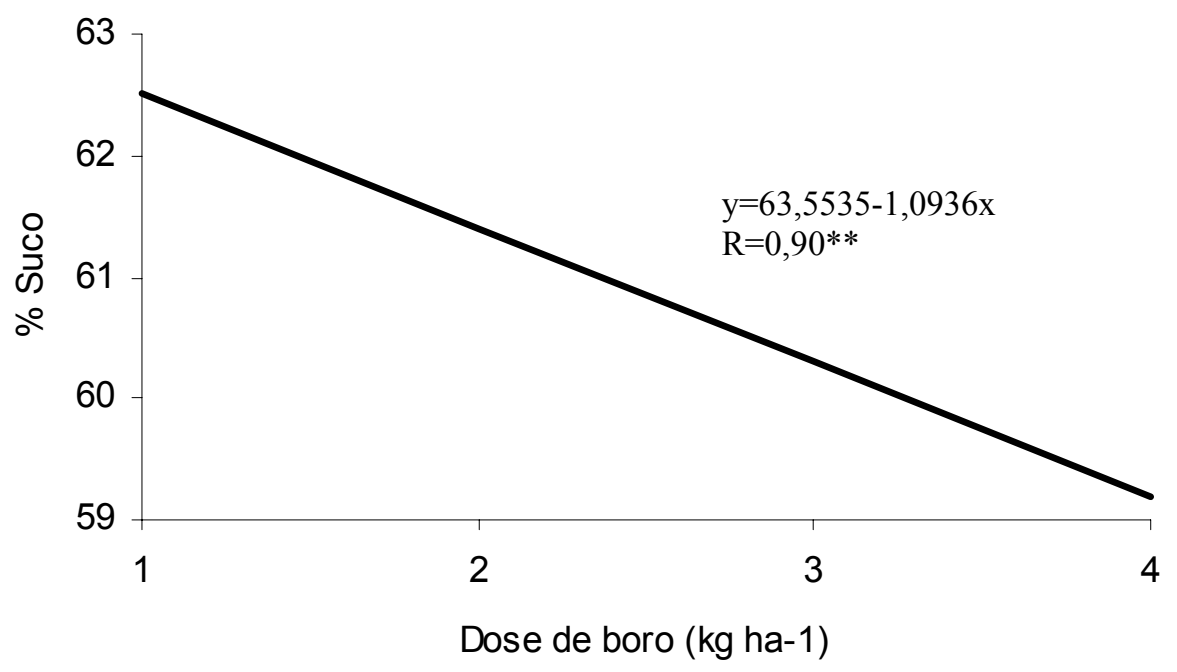

Figura 9- Correlação entre doses de boro aplicadas no solo e porcentagem de suco

\subsubsection{Atributos físicos dos frutos}

Na Tabela 27 verifica-se que não houve diferença estatística significativa dos tratamentos aplicados nas características físicas dos frutos, tais como diâmetro, espessura de casca e número de frutos por caixa. 
Tabela 27. Atributos físico dos frutos avaliados para cada tratamento

\begin{tabular}{|c|c|c|c|}
\hline \multirow[t]{2}{*}{ Tratamento } & Diâmetro fruto & Espessura casca & \multirow[t]{2}{*}{$\begin{array}{l}\text { Número de } \\
\text { frutos/caixa }\end{array}$} \\
\hline & \multicolumn{2}{|c|}{------------(mm)----------- } & \\
\hline T1-Ulexita pó $\left(1 \mathrm{kgB} \mathrm{ha}^{-1}\right)$ & $61,9 \mathrm{a}$ & $2,8 \mathrm{a}$ & $296 a$ \\
\hline T2-Ulexita pó $\left(2 \mathrm{kgB} \mathrm{ha}^{-1}\right)$ & $63,0 \mathrm{a}$ & $3,2 \mathrm{a}$ & $284 a$ \\
\hline T3-Ulexita pó $\left(3 \mathrm{kgB} \mathrm{ha}^{-1}\right)$ & $62,7 \mathrm{a}$ & $3,1 \mathrm{a}$ & $297 \mathrm{a}$ \\
\hline T4-Ulexita pó $\left(4 \mathrm{kgB} \mathrm{ha}^{-1}\right)$ & $62,5 \mathrm{a}$ & $3,3 \mathrm{a}$ & $317 \mathrm{a}$ \\
\hline T5-Colemanita pó $\left(1 \mathrm{kgB} \mathrm{ha}^{-1}\right)$ & $59,1 \mathrm{a}$ & $3,1 \mathrm{a}$ & $309 a$ \\
\hline T6-Colemanita pó $\left(2 \mathrm{kgB} \mathrm{ha}^{-1}\right)$ & $64,7 \mathrm{a}$ & $3,3 a$ & $275 a$ \\
\hline T7-Colemanita pó $\left(3 \mathrm{kgB} \mathrm{ha}^{-1}\right)$ & $59,9 a$ & $2,9 \mathrm{a}$ & $306 a$ \\
\hline T8-Colemanita pó $\left(4 \mathrm{kgB} \mathrm{ha}^{-1}\right)$ & $60,4 a$ & $3,2 \mathrm{a}$ & $313 a$ \\
\hline T9-Ulexita gran. $\left(1 \mathrm{kgB} \mathrm{ha}^{-1}\right)$ & $64,0 \mathrm{a}$ & $3,2 \mathrm{a}$ & $278 \mathrm{a}$ \\
\hline T10-Ulexita gran. $\left(2 \mathrm{kgB} \mathrm{ha}^{-1}\right)$ & $61,5 \mathrm{a}$ & $3,0 \mathrm{a}$ & $322 a$ \\
\hline T11-Ulexita gran. $\left(3 \mathrm{kgB} \mathrm{ha}^{-1}\right)$ & $62,3 a$ & $3,2 \mathrm{a}$ & $308 \mathrm{a}$ \\
\hline T12-Ulexita gran. $\left(4 \mathrm{kgB} \mathrm{ha}^{-1}\right)$ & $61,0 \mathrm{a}$ & $3,0 \mathrm{a}$ & $298 \mathrm{a}$ \\
\hline T13-Termofosfato-B $\left(1 \mathrm{kgB} \mathrm{ha}^{-1}\right)$ & $64,2 \mathrm{a}$ & $2,9 \mathrm{a}$ & $290 \mathrm{a}$ \\
\hline T14-Termofosfato-B $\left(2 \mathrm{kgB} \mathrm{ha}^{-1}\right)$ & $60,2 \mathrm{a}$ & $3,0 \mathrm{a}$ & $315 \mathrm{a}$ \\
\hline T15-Termofosfato-B $\left(3 \mathrm{kgB} \mathrm{ha}^{-1}\right)$ & $61,4 a$ & $3,1 \mathrm{a}$ & $317 \mathrm{a}$ \\
\hline T16-Termofosfato-B $\left(4 \mathrm{kgB} \mathrm{ha}^{-1}\right)$ & $63,2 \mathrm{a}$ & $2,9 \mathrm{a}$ & $300 a$ \\
\hline T17-Ácido bórico $\left(1 \mathrm{kgB} \mathrm{ha}^{-1}\right)$ & $64,2 \mathrm{a}$ & $3,3 \mathrm{a}$ & $281 \mathrm{a}$ \\
\hline T18-Ácido bórico $\left(2 \mathrm{kgB} \mathrm{ha}^{-1}\right)$ & $64,5 \mathrm{a}$ & $3,1 \mathrm{a}$ & $293 a$ \\
\hline T19-Ácido bórico $\left(3 \mathrm{kgB} \mathrm{ha}^{-1}\right)$ & $62,9 a$ & $3,1 \mathrm{a}$ & $293 a$ \\
\hline T20-Ácido bórico $\left(4 \mathrm{kgB} \mathrm{ha}^{-1}\right)$ & $64,3 a$ & $3,2 \mathrm{a}$ & $287 \mathrm{a}$ \\
\hline T21-Termofosfato-Mg $\left(250 \mathrm{~kg} \mathrm{ha}^{-1}\right)$ & $63,9 a$ & $3,0 \mathrm{a}$ & $283 a$ \\
\hline T22-Termofosfato-Mg $\left(500 \mathrm{~kg} \mathrm{ha}^{-1}\right)$ & $58,6 \mathrm{a}$ & $2,7 \mathrm{a}$ & $326 a$ \\
\hline T23-Termofosfato-Mg $\left(750 \mathrm{~kg} \mathrm{ha}^{-1}\right)$ & $63,3 a$ & $3,1 \mathrm{a}$ & $306 a$ \\
\hline T24-Termofosfato-Mg $\left(1000 \mathrm{~kg} \mathrm{ha}^{-1}\right)$ & $62,8 \mathrm{a}$ & $2,7 \mathrm{a}$ & $313 a$ \\
\hline T25- Testemunha & $61,8 \mathrm{a}$ & $3,2 \mathrm{a}$ & $318 \mathrm{a}$ \\
\hline Valor F & $1,3 \mathrm{~ns}$ & $0,7 \mathrm{~ns}$ & $0,6 \mathrm{~ns}$ \\
\hline CV $(\%)$ & 4,8 & 13,1 & 13,1 \\
\hline DMS & 8,0 & 1,1 & 105,9 \\
\hline
\end{tabular}

Médias de quatro repetições contidas em colunas, seguidas de mesma letra não diferem entre si pelo teste de Tukey. * e **: nível de significância de 5 e 1\% respectivamente. ns: não significativo

A aplicação de boro no solo, por proporcionar maior desenvolvimento radicular e conseqüentemente maior aproveitamento dos nutrientes e da água do solo, deveria refletir em maior diâmetro dos frutos (Tabela 28) e conseqüentemente no menor número 
de frutos por caixa (Tabela 29), características essas bastante influenciadas em plantas afetadas pela $\mathrm{CVC}$, as quais possuem a característica de absorverem menores quantidades de água do solo, gerando menores taxas de fotossíntese, o que reflete diretamente no tamanho dos frutos (Medina, 2002a); porém no presente trabalho não verificou-se esse efeito de fonte e doses de boro (ANEXO A).

Tabela 28. Avaliação do diâmetro do fruto, em mm, para cada fonte e dose de boro utilizada

\begin{tabular}{lcccc}
\hline Fonte & \multicolumn{4}{c}{ Doses B $\left(\mathrm{kg} \mathrm{ha}^{-1}\right)$} \\
& 1 & 2 & 3 & 4 \\
\hline Ulexita- pó & $61,9 \mathrm{a}$ & $63,0 \mathrm{a}$ & $62,7 \mathrm{a}$ & $62,5 \mathrm{a}$ \\
Colemanita- pó & $59,1 \mathrm{a}$ & $64,7 \mathrm{a}$ & $59,9 \mathrm{a}$ & $60,4 \mathrm{a}$ \\
Ulexita- gran. & $64,0 \mathrm{a}$ & $61,5 \mathrm{a}$ & $62,3 \mathrm{a}$ & $61,0 \mathrm{a}$ \\
Termofosfato-B & $64,2 \mathrm{a}$ & $60,2 \mathrm{a}$ & $61,4 \mathrm{a}$ & $63,2 \mathrm{a}$ \\
Ácido bórico & $64,2 \mathrm{a}$ & $64,5 \mathrm{a}$ & $62,9 \mathrm{a}$ & $64,3 \mathrm{a}$ \\
\hline
\end{tabular}

Médias de quatro repetições seguidas de mesma letra na coluna não diferem entre si pelo teste de Tukey a 5\% de significância

Tabela 29. Avaliação do número de frutos por caixa de $40,8 \mathrm{~kg}$ para cada fonte e dose de boro utilizadas

\begin{tabular}{lcccc}
\hline Fonte & \multicolumn{4}{c}{ Doses B $\left(\mathrm{kg} \mathrm{ha}^{-1}\right)$} \\
& 1 & 2 & 3 & 4 \\
\hline Ulexita- pó & $296 \mathrm{a}$ & $284 \mathrm{a}$ & $297 \mathrm{a}$ & $317 \mathrm{a}$ \\
Colemanita- pó & $309 \mathrm{a}$ & $275 \mathrm{a}$ & $306 \mathrm{a}$ & $313 \mathrm{a}$ \\
Ulexita- gran. & $278 \mathrm{a}$ & $322 \mathrm{a}$ & $308 \mathrm{a}$ & $298 \mathrm{a}$ \\
Termofosfato-B & $290 \mathrm{a}$ & $315 \mathrm{a}$ & $317 \mathrm{a}$ & $300 \mathrm{a}$ \\
Ácido bórico & $281 \mathrm{a}$ & $293 \mathrm{a}$ & $293 \mathrm{a}$ & $287 \mathrm{a}$ \\
\hline
\end{tabular}

Médias de quatro repetições seguidas de mesma letra na coluna não diferem entre si pelo teste de Tukey a 5\% de significância

O uso de diferentes fonte de boro também não influenciou a medida da espessura da casca do fruto (Tabela 30), não havendo diferença significativa para o aumento das doses de boro (ANEXO A). 
Tabela 30. Avaliação da espessura da casca do fruto, em mm, para cada fonte e dose de boro utilizadas

\begin{tabular}{lcccc}
\hline Fonte & \multicolumn{4}{c}{ Doses B $\left(\mathrm{kg} \mathrm{ha}^{-1}\right)$} \\
& 1 & 2 & 3 & 4 \\
\hline Ulexita- pó & $2,8 \mathrm{a}$ & $3,2 \mathrm{a}$ & $3,1 \mathrm{a}$ & $3,3 \mathrm{a}$ \\
Colemanita- pó & $3,1 \mathrm{a}$ & $3,3 \mathrm{a}$ & $2,9 \mathrm{a}$ & $3,2 \mathrm{a}$ \\
Ulexita- gran. & $3,2 \mathrm{a}$ & $3,0 \mathrm{a}$ & $3,2 \mathrm{a}$ & $3,0 \mathrm{a}$ \\
Termofosfato-B & $2,9 \mathrm{a}$ & $3,0 \mathrm{a}$ & $3,1 \mathrm{a}$ & $2,9 \mathrm{a}$ \\
Ácido bórico & $3,3 \mathrm{a}$ & $3,1 \mathrm{a}$ & $3,1 \mathrm{a}$ & $3,2 \mathrm{a}$ \\
\hline Médias de quatro repetições seguidas de mesma letra na coluna não diferem entre si \\
pelo teste de Tukey a 5\% de significância
\end{tabular}




\section{CONCLUSÕES}

Os resultados do presente estudo permitiram concluir que:

a) as fontes de boro aplicadas no solo foram eficientes em aumentar o teor foliar de boro;

b) as fontes, ácido bórico e ulexita pó, foram as que promoveram os maiores aumentos nos teores foliares de boro;

c) não houve influência significativa de doses e fontes de boro nos teores foliares de fósforo, cálcio e magnésio;

d) os teores de boro no solo foram mantidos acima do nível crítico pela utilização das fontes, tendo determinado maiores valores onde utilizou-se fontes menos solúveis como a colemanita e o termofosfato contendo boro, em avaliação realizada 11 meses após a aplicação dos tratamentos;

e) os teores no solo de fósforo, cálcio, magnésio e saturação por bases foram influenciados significativamente pelas doses de boro;

f) a produtividade do pomar e atributos físicos dos frutos não tiveram influência da utilização de fontes e doses de boro no pomar com elevada incidência de CVC;

g) a utilização de boro diminui a porcentagem de suco no fruto, não afetando as demais características tecnológicas do fruto. 
ANEXOS 


\section{ANEXO A}

Tabela 31. Funções para variação nas doses de boro nas seguintes variáveis

\begin{tabular}{llcc}
\hline Variável & Função & $\mathrm{R}^{2}$ & Teste F \\
\hline P- folha & $\mathrm{Y}=1,015+0,012 \mathrm{X}$ & 0,90 & $\mathrm{~ns}$ \\
Ca- folha & $\mathrm{Y}=36,8325-0,0435 \mathrm{X}$ & 0,55 & $\mathrm{~ns}$ \\
Mg- folha & $\mathrm{Y}=3,4337-0,27375 \mathrm{X}+0,06625 \mathrm{X}^{2}$ & 0,90 & $\mathrm{~ns}$ \\
Produção & $\mathrm{Y}=36,835+5,97 \mathrm{X}$ & 0,61 & $\mathrm{~ns}$ \\
RATIO & $\mathrm{Y}=14,70-0,3274 \mathrm{X}$ & 0,05 & $\mathrm{~ns}$ \\
Sólidos solúveis & $\mathrm{Y}=2,8986+0,1734 \mathrm{X}$ & 0,85 & $\mathrm{~ns}$ \\
${ }^{\circ}$ BRIX & $\mathrm{Y}=11,918+0,1619 \mathrm{X}$ & 0,56 & $\mathrm{~ns}$ \\
Espessura casca & $\mathrm{Y}=3,0487+0,02025 \mathrm{X}$ & 0,34 & $\mathrm{~ns}$ \\
Diâmetro fruto & $\mathrm{Y}=62,90975-0,208799 \mathrm{X}$ & 0,39 & $\mathrm{~ns}$ \\
Número de frutos/caixa & $\mathrm{Y}=288,2+4,34 \mathrm{X}$ & 0,83 & $\mathrm{~ns}$ \\
\hline
\end{tabular}

\section{ANEXO B}

Tabela 32. Dados de temperatura, umidade relativa e precipitação média da área experimental durante os meses de outubro/2001 a agosto/2002

\begin{tabular}{lccc}
\hline \multicolumn{1}{c}{ MÊS/ANO } & $\begin{array}{c}\text { Temperatura } \\
\left({ }^{\circ} \mathrm{C}\right)\end{array}$ & $\begin{array}{c}\text { Umidade } \\
\text { Relativa }\end{array}$ & $\begin{array}{c}\text { Precipitação } \\
(\mathrm{mm})\end{array}$ \\
\hline Outubro/2001 & 24,6 & $(\%)$ & 106,8 \\
Novembro/2001 & 25,4 & 60,2 & 264,5 \\
Dezembro/2001 & 25,1 & 71,7 & 362,1 \\
Janeiro/2002 & 25,8 & 75,6 & 200,6 \\
Fevereiro/2002 & 24,4 & 80,6 & 445,3 \\
Março/2002 & 26,3 & 83,7 & 19,1 \\
Abril/2002 & 26,9 & 64,6 & 0,0 \\
Maio/2002 & 23,6 & 48,4 & 31,7 \\
Junho/2002 & 23,8 & 56,5 & 0,0 \\
Julho/2002 & 22,3 & 44,8 & 15,4 \\
Agosto/2002 & 25,4 & 47,2 & 13,1 \\
\hline
\end{tabular}




\section{REFERÊNCIAS BIBLIOGRÁFICAS}

AGARWALA, S.C.; SHARMA, P.N.; CHATTERJEE, C.; SHARMA， C.P. Development and enzymatic changes during pollen development in boron deficient maize plants. Journal of Plant Nutrition, v.3, n.1/4, p.329-336, 1981.

AYRES, A.J. Intensidade da clorose variegada dos citros em pomares comerciais do Estado de São Paulo e sul do Triângulo Mineiro. Jaboticabal, 2000. 59p. Dissertação (Mestrado) - Faculdade de Ciências Agrárias e Veterinárias, Universidade Estadual Paulista "Julio de Mesquita Filho".

BARNARD, R.; FULCHER, W.J.; OBERHOLZER, P.C.J. The uptake of $\mathrm{Zn}, \mathrm{Mn}, \mathrm{Cu}$ and B from spray mixtures by navel oranges leaves. Plant and Soil, v.39, p.429$432,1973$.

BENNETT, D.M. Silicon deposition in the roots of Hordeum sativum Jess, Avena sativa L. and Triticum aestivum L. Annuals of Botany, v.50, p.239-254, 1982.

BIGGAR, J.W.; FIREMAN, M. Boron adsorption and release by soils. Soil Science Society of America Proceedings, v.24, p.115-120, 1960. 
BINGHAM, F.T.; MARTIN, J.P.; CHASTAIN, J.A. Effects of phosphorus fertilization of California soils on minor element nutrition of citrus. Soil Science, v.186, p.24-31, 1957.

BRADFORD, G.R. Boron. In: CHAPMAN, H.D (Ed.). Diagnostic criteria for plants and soils. Riverside: University of California, 1966. cap.4, p.33-61.

BYERS, D.E.; MIKKELSEN, R.L.; COX, F.R. Greenhouse evaluation of four boron fertilizer materials. Journal of Plant Nutrition. v.24, n.4/5, p.717-725, 2001.

CABRITA, J.R.M. Aplicação de boro, manganês e zinco em citros, vias solo e foliar. Piracicaba, 1993. 47p. Dissertação (Mestrado) - Escola Superior de Agricultura “Luiz de Queiroz”, Universidade de São Paulo.

CAKMAK, I.; KURZ, H.; MARSCHNER, H. Short-term effects of boron, germanium and high light intensity on membrane permeability in boron deficient leaves of sunflower. Physiologia Plantarum, v.95, p.11-18, 1995.

CARVALHO, M.L.V. Situação atual da clorose variegada dos citros e estratégias de controle. Fitopatologia Brasileira, v.21, p.328-330, 1996.

CASTRO, P.R.C. Aspectos fisiológicos do amarelinho. In: ENCONTRO TÉCNICO SOBRE AMARELINHO DOS CITROS, Piracicaba:ESALQ, 1992. p.24-26.

CHATTERJIE, C.; SINHA, P.; NAUTIYAL, N.; AGARWALA, S.C.; SHARMA, C.P. Metabolic changes associated with boron-calcium interaction in maize. Soil Science and Plant Nutrition, v.33, n.4, p.607-617, 1987. 
COMISSÃO DE FERTILIDADE DO SOLO DO ESTADO DE MINAS GERAIS. Recomendações para o uso de corretivos e fertilizantes em Minas Gerais. Viçosa: Universidade Federal de Viçosa, 1999. 359p.

CORREA, A.E.; PAVAN, M.A.; MIYAZAMA, M. Aplicação de boro no solo e respostas do cafeeiro. Pesquisa Agropecuária Brasileira, v.20, n.2, p.177-181, 1985.

DANTAS, J.P. Micronutrientes no solo: boro. In: FERREIRA, M.E.; CRUZ, M.C. (Ed.). Micronutrientes na agricultura. Piracicaba: Associação Brasileira para Pesquisa da Potassa e do Fosfato, 1991. cap.5, p.113-125, 1991.

DE NEGRI, J.D. Clorose variegada dos citros: nova anomalia afetando pomares em São Paulo e Minas Gerais. Campinas: CATI, 1990. 6p. (Comunicação Técnica, 82).

DECHEN, A.R.; HAAG, H.P.; CARMELLO, Q.A. Funções dos micronutrientes nas plantas: mecanismos de absorção e de translocação de micronutrientes. In: FERREIRA, M.E.; CRUZ, M.C. (Ed.). Micronutrientes na agricultura. Piracicaba: Associação Brasileira para Pesquisa da Potassa e do Fosfato, 1991. cap.3, p.65-97.

DEL RIVERO, J.M. Los estados de carencia em los agrios. Madrid: Intituto Nacional de Investigaciones Agronomicas, 1964. 353p.

EMPRESA BRASILEIRA DE PESQUISA AGROPECUÁRIA. Centro Nacional de Pesquisa de Solos. Sistema brasileiro de classificação de solos. Rio de Janeiro, 1999. 412p.

EPSTEIN, E. Nutrição mineral das plantas: princípios e perspectivas. Rio de Janeiro: Livros técnicos e científicos, 1975. 341p. 
FEICHTENBERGER, E.; MÜLLER, G.W.; GUIRADO, N. Doenças dos citros. In: KIMATI, H,; AMORIM, L.; BERGAMIM FILHO, A.; CAMARGO, L.E.A.; REZENDE, J.A.M. (Ed.). Manual de fitopatologia. São Paulo: Editora Agronômica Ceres, 1997. cap.25, p.261-296.

FNP CONSULTORIA \& COMÉRCIO. Agrianual 2003: anuário da agricultura brasileira. São Paulo, 2003. 545p.

FUNDECITRUS. Fundecitrus. Estatísticas - CVC. http://www.fundecitrus.com.br/ escvc.html (12 jan.2003).

GONÇALVES, J.R. Mutante entra na guerra ao amarelinho. Folha de São Paulo, São Paulo, 15 jan 2002. p.F1.

GRAHAM, R.D.; WEBB, M.J. Micronutrients and desease resistence and tolerance in plants. In: MORTVEDT, J.J.; COX, F.R.; SHUMAN, C.M.; WILCH, R.M. (Ed.). Micronutrients in agriculture. Madison: Soil Science Society of America Book Services, 1991. cap.10, p.329-370.

GRASSI FILHO, H. Níveis de cálcio e boro e suas interações, afetando o desenvolvimento do sistema radicular, a composição mineral e o vigor do limoeiro Cravo (Citrus limonia (L.) OSBECK), em condições controladas. Piracicaba, 1991. 92p. Dissertação (Mestrado) - Escola Superior de Agricultura "Luiz de Queiroz", Universidade de São Paulo.

GRASSI FILHO, H. Adições de cálcio e boro influenciando características fenológicas e composição foliar do limoeiro Siciliano enxertado sobre dois porta-enxertos. Piracicaba, 1995. 77p. Tese (Doutorado)- Escola Superior de Agricultura "Luiz de Queiroz”, Universidade de São Paulo. 
GRAVENA, S.; LOPES, J.R.S.; PAIVA, P.E.B.; YAMAMOTO, P.T.; ROBERTO, S.R. Os vetores da Xylella fastidiosa. In.: DONADIO, L.C.; MOREIRA, C.S. (Ed.). Clorose variegada dos citros. Bebedouro: Fundecitros, 1997. cap.2, p.22-36.

GRUPO PAULISTA DE ADUBAÇÃO E CALAGEM PARA CITROS. Recomendações de adubação e calagem para citros no Estado de São Paulo. Cordeirópolis: GPACC, 1994. 27p. (Edição Especial).

GUPTA, U.C. Relationship of total and hot water soluble boron, and fixation of added boron, to properties of podzol soils. Soil Science Society of America Proceedings, v.32, p.45-48, 1968.

GUPTA, U.C. Interaction effects of boron and lime on barley. Soil Science Society of America Proceedings, v.36, p.332-334, Jan./Feb., 1972.

GUPTA, U.C. Factors affecting boron uptake by plants. In: GUPTA, U.C (Ed). Boron and its role in crop production. Boca Raton: CRC Press, 1993. cap 5, p. 87-104.

GUPTA, U.C.; CUTCLIFFE, J.A. Effects of lime and boron on brown-heart, leaf tissue calcium/boron rations, and boron concentrations of rutagaba. Soil Science Society of America Proceedings, v.36, p.936-939, July/Aug., 1972.

GUPTA, U.C.; CUTCLIFFE, J.A. Effects of methods of boron application on leaf tissue concentration of boron and control of brown-heart in rutabaga. Canadian Journal of Plant Science, v.58, n.63, p.231-234, 1978.

GURGEL, M.N.A. Efeitos do silicato de cálcio e sua interação com o fósforo no estado nutricional, produtividade e qualidade tecnológica da cana-de-açúcar (Saccharum sp.). Piracicaba, 1979. 62p. Dissertação (Mestrado) - Escola Superior de Agricultura "Luiz de Queiroz”, Universidade de São Paulo. 
HOPKINS, D.L. Xylella fastidiosa: xylem-limited bacterial pathogen of plants. Annual Review of Phytopathology, v.22, p.271-290, 1989.

HORTENSTINE, C.C.; ASHLEY, D.A.; WEAR, J.I. An evaluation of slowly soluble boron materials. Soil Science Society of America Proceedings, v.29, p.249-251, 1958.

HUNTER, I.R.; WILL, G.M.; SKINNER, M.F. A strategy for the correction of boron deficiency in radiate pine plantations in New Zealand. Forest Ecology and Management, v.37, p.77-82. 1990.

JACOMINO, A.P.; MODESTO, J.C.; BERETA, M.J.G.; TUBELIS, A.; LEITE, R.M.V.B.; SALIBE, A.A. Transmissão controlada da Clorose Variegada dos Citros (CVC). Fitopatologia Brasileira, v.18, p.265, 1993. Suplemento.

KAMPFER, M.; UEXKULL, H.R. von. Nuevos conocimientos sobre la fertilización de los cítricos. 3.ed. Hanover: Verlag Gesselschaft fur Ackerbau, 1966. 492p.

KORNDÖRFER, G.H.; PEREIRA, H.S. Possíveis interações entre silício e declíneo. Citricultura Atual, n.26, p.12-13, 2002.

KORNDÖRFER, G.H.; PEREIRA, H.S.; CAMARGO, M.S. de. Silicatos de cálcio e magnésio na agricultura. Uberlândia: Universidade Federal de Uberlândia, 2002. 23p. (Grupo de Pesquisa "Silício na Agricultura”. Boletim Técnico, 1).

LANNING, F.C.; ELEUTERIUS, L.N. Silica deposition in some C3 and C4 species of grasses, sedges and composites in the USA. Annuals of Bothany, v.63, p.395-410, 1989. 
LARANJEIRA, F.F. Dez anos de clorose variegada dos citros: o que sabemos? Laranja, v.18, n.1, p.123-141, 1997.

LARANJEIRA, F.F.; PALAZZO, D.A. Danos qualitativos à produção de laranja 'Natal' causados pela clorose variegada dos citros. Laranja, v.20, n.1, p.77-91, 1999.

LAVÍN, A.A. Boron toxicity induced by ulexite applications in some drip irrated fruit crops at Cauquenes, Chile. Agricultura Técnica, v.48, n.2, p.167-170, 1988.

LENOBLE, M.E.; BLEVINS, D.G.; MILES, R.J. Extra boron maintains root growth under toxic aluminum conditions. Better Crops, p.3-5, Summer, 1993.

LEU, L.S.; SU, C.C. Isolations, cultivation and pathogenicity of Xylella fastidiosa, the causal bacterium of pear leaf scorch disease in Taiwan. Plant Disease, v.77, n.6, p.642-646, 1993.

LIMA, J.E.O.; MIRANDA, V.S.; COUTINHO, A.; ROBERTO, S.R.; CARLOS, E.F. Distribuição de Xylella fastidiosa no cafeeiro, nas regiões cafeeiras e seu isolamento in vitro. Fitopatologia Brasileira, v.21, n.3, p.392-393, 1996.

LOPES, J.R.S. Mecamismos de transmissão de Xylella fastidiosa por cigarrinhas. Laranja, v.17, p.79-92, 1996.

MACHADO, E.C.; QUAGGIO, J.A.; LAGÔA, A.M.M.A.; TICELLI, M.; FURLANI, P.R. Trocas gasosas e relações hídricas em laranjeiras com clorose variegada dos citros. Revista Brasileira de Fisiologia Vegetal, v.6, n.1, p.53-57, 1994.

MALAVOLTA, E. Manual de química agrícola: adubos e adubação. São Paulo: Editora Agronômica Ceres, 1987. 606p. 
MALAVOLTA, E.; KLIEMANN, H.J. Desordens nutricionais no cerrado. Piracicaba: Potafos, 1985. 136p.

MALAVOLTA, E.; VIOLANTE NETTO, A. Nutrição mineral, calagem, gessagem e adubação dos citros. Piracicaba: Associação Brasileira para Pesquisa da Potassa e do Fosfato, 1989. 153p.

MALAVOLTA, E.; PRATES, H.S. Alterações na composição mineral das folhas de pomares cítricos afetados pela anomalia "amarelinho" ou clorose variegada. Laranja, v.12, n.2, p.315-329, 1991.

MALAVOLTA, E.; PRATES, H.S.; PINTO, W.B.S. Levantamento e observações sobre o "amarelinho" ou "clorose variegada" dos citros. Laranja, v.13, n.2, p.503-513, 1992.

MALAVOLTA, E.; VITTI, G.C.; OLIVEIRA, S.A. de. Avaliação do estado nutricional das plantas. 2.ed. Piracicaba: Associação Brasileira para pesquisa da Potassa e do Fosfato, 1997. 319p.

MARSCHNER, H. Functions of mineral nutrients: micronutrients. In: MARSCHNER, H. Mineral nutrition of higher plants. London: Academic Press, 1995a. cap.9, p.313-404.

MARSCHNER, H. Beneficial mineral elements: silicon. In: MARSCHNER, H. Mineral nutrition of higher plants. London: Academic Press, 1995b. cap.10, p.405-435.

MARTINI, F.; THELLIER, M. Use an $(n, \alpha)$ nuclear reaction to study the long-distance transport of boron in Trifolium repens L. after foliar application. Planta, v.150, n.197, p.34-39, 1980. 
MATHAI, G.; PAILY, P.V.; MENON, M.R. Effect of fungicides and silica in the control of sheath blight disease of rice caused by Corticum sasakii (Shiriai). Agricultural Research Journal of Kerala, v.19, n.1, p.79-83, 1978.

MATICHENKOV, V.; CALVERT, D.; SNYDER, G. Silicon fertilizers for citrus in Florida. Proceedings of the Florida State for Horticultural Society, v.112, p.5-8, 1999.

MATTOS JUNIOR., D.; QUAGGIO, A.J.; CANTARELlA, H. Calagem e adubação dos citros. Informe Agropecuário, v.22, n.209, p.39-46, 2001.

MEDINA, C.L. Fotossíntese, relações hídricas e alterações bioquímicas em laranjeira "Pêra" com CVC e submetida à deficiência hídrica. Campinas, 2002a. 147p. Tese (Doutorado)- Universidade de Campinas.

MEDINA, C.L. Fisiologia das plantas com clorose variegada dos citros. Citricultura Atual, n.30, p.8-10, 2002b.

MENGEL, K.; KIRKBY, E.A. Boron. In: MENGEL, K.; KIRKBY, E.A. Principles of plant nutrition. Bern: International Potash Institute, 1982. cap.18, p.533-541.

MENZIES, J.; BOWEN, P.; EHRET, D. Foliar applications of potassium silicate reduce severity of powdery mildew on Cumcumber, Muskemelon and Zucchini Squash. Journal of the American Society for Horticultural Science, v.117, n.6, p.902-905, 1992.

MIYAKE,Y.; TAKAHASHI, E. Effect of silicon on the growth of cucumber plant in soil culture. Soil Science and Plant Nutrition, v.29, p.463-471, 1983. 
MORAGHAN, J.T.; MASCAGNI, H.J. Environmental and soil factors affecting micronutrient deficiencies and toxicities. In: MORTVEDT, J.J.; COX, F.R.; SHUMAN, C.M.; WILCH, R.M. (Ed.). Micronutrients in agriculture. Madison: Soil Science Society of America Book Services, 1991. cap.11, p.371-425.

MORTVEDT, J.J. Needs for controlled-availability micronutrient fertilizers. Fertilizer Research, n.38, p.213-221, 1994.

MURPHY, L.S.; WALSH, L.M. Fertilizer applications for correcting micronutrient deficiencies. In: MORTVEDT, J.J.; GIORDANO, P.M.; LINDSAY, W.L. Micronutrients in agriculture. Madison: Soil Science Society of America. 1972, cap.15, p.347-387.

OLIVEIRA, R.F.; MACHADO, E.C.; MARIN, F.R.; MEDINA, C.L. Sap flow rates and stomatal conductance of sweet orange 'Pêra' (Citrus sinensis L.Osb.) infected by Xylella fastidiosa. In: INTERNATIONAL SOCIETY OF CITRICULTURE CONGRESS, 9. Lake Alfred, 2000. Abstracts. Lake Alfred: APC, 2000. p.161.

PALAZZO, D.A. Estimativas de perdas de laranja 'Natal' por clorose variegada dos citros. Laranja, v.14, p.211-226, 1993.

PAVAN, M.A.; CORREA, A.E. Reações de equlíbrio solo-boro. Pesquisa Agropecuária Brasileira, v.23, n.3, p.261-269, 1988.

PURCELL, A.H.; HOPKINS, D.L. Fastidious xylem-limited bacterial plant pathogen. Annuals Review of Phytopathology, v. 34, p. 131-151, 1996.

RAIJ, B.van. Fertilidade do solo e adubação. Piracicaba: Editora Agronômica Ceres, 1991. 343p. 
RAIJ, B. van; ANDRADE, J.C.; CANTARELlA, H.; QUAGGIO, J.A. (Ed.). Análise química para avaliação da fertilidade de solos tropicais. Campinas: Instituto Agronômico, 2001. 285p.

RAJU, B.C.; WELLS, J.M. Disease caused by fastidious Xylem-limited. Plant Disease, v.70, n.3, p.182, 1986.

RODRIGUEZ, O. Aspectos fisiológicos, nutrição e adubação dos citros. In: RODRIGUEZ, O.; VIÉGAS, F.; POMPEU JUNIOR., J.; AMARO, A.A. Citricultura brasileira. Campinas: Fundação Cargill, 1991. v.1, cap.14, 419-475.

ROSSETTI, V.; DE NEGRI, J.D. Clorose variegada dos citros: revisão. Laranja, v.11, n.1, p.1-14, 1990.

ROTHUBUR, R.; SCOTT, F. A study of the uptake silicon and phosphorus by wheat plants with radio chemical methods. Biochemical Journal, v.65, p.241-245, 1957.

SANCHEZ, P; UEHARA, G. Management considerations for acid soils with high phosphorus fixation capacity. In: KHASAWNECH, F.E.; SAMPLE, E.C.; KÄMPRATH, E.J. The role of phosphorus in agriculture. Madison: ASA, 1980. p.471-514.

SHELP, B.J. Physiology and biochemistry of boron in plants. In: GUPTA, U.C. Boron and its role in crop production. Boca Raton: CRC Press, 1993. cap 4, p. 53-85.

SINGH, S.S. Boron adsorption equilibrium in soils. Soil Science, v.98, p.383-387, 1964. 
SMITH, P.F. Boron deficiency in Florida citrus groves. Proceedings of the Florida State for Horticultural Society, v.67, p.69-73, 1954.

SMITH, P.F. Leaf analysis of citrus. In: CHILDERS, N.F. (Ed.). Fruit nutrition. New Brunswick: Horticultural Publications Rutgers, 1966. cap.2, p.208-228.

SOUZA, E.C.A.; YASUDA, M. Uso agronômico do termofosfato no Brasil. São Paulo: Fertilizantes Mitsui, 1995. 60p.

STOREY, R.; TREEBY, M.T. Seasonal changes in nutrient concentration of navel orange fruit. Scientia Horticulturae, v.84, n.1/2, p. 67-82, 2000.

TIBAU, A.C. Matéria orgânica e fertilidade do solo. 3.ed. São Paulo: Editora Nobel, 1984. 220p.

TISDALE, S.L.; NELSON, W.L.; BEATON, J.D. Micronutrients and other beneficial elements in soils and fertilizers. In: TISDALE, S.L.; NELSON, W.L.; BEATON, J.D (Ed.). Soil fertility and fertilizers. New York: Macmillan, 1985. cap.9, p.350413.

TRAVENSOLO, R.F.; LEITE, JUNIOR., R.P. Hospedeiros alternativos de Xylella fastidiosa entre plantas invasoras de pomares de citros com Clorose Variegada. Fitopatologia Brasileira, v.21, p.24-29, 1996. Suplemento.

VITTI, G.C. Avaliação e interpretação do enxofre no solo e na planta. Jaboticabal: FUNEP, 1988. 37p.

VITTI, G.C. Nutrição e crescimento de plantas cítricas. In: SEMINÁRIO INTERNACIONAL DE FISIOLOGIA DOS CITROS, 2., Bebedouro, 1992. Anais. Campinas: Fundação Cargill, 1992. p.133-162. 
VITTI, G.C.; MARCHI, R.J.; BORELLA, M.L.; VAZ FILHO, D. Estudo de prováveis desequilíbrios nutricionais em pomares cítricos no município de Colina-SP. Jaboticabal: UNESP, 1989. 12p.

WELLS, J.M.; RAJU, B.C.; JUNG, H.Y.; WEISBURG, W.G.; MANDELCO-PAUL, L.; BRENNER, D.J. Xylella fastidiosa gen nov., sp. Nov. gramnegative, xylem limited fastidious plant bacteria related to Xanthomonas spp. International Journal of Systematic Bacteriology, v. 37, p.136-143, 1987.

WOJEIK, P. Effect of boron fertilization on uptake and distribution of selected mineral nutrients in "Elstar" apple. Journal of Fruit and Ornamental Plant Research, v.7, p.119-131, 1999.

WUTSCHER, H.K. Growth and mineral nutrition of young orange trees grown with high levels of silicon. HortScience, v.24, n.2, p.275-277, 1989.

YAMADA, T. Boro: será que estamos aplicando a dose suficiente para o adequado desenvolvimento das plantas? Informações Agronômicas, n.90, p.1-5, 2000.

YAMAMOTO, P.T; ROBERTO, S.R. Aspectos relacionados às principais espécies de cicadelíneos (Hemiptera: Cicadellidae: Cicadellinae) que ocorrem em citros. In: CONGRESSO BRASILEIRO DE FRUTICULTURA, 16., Salvador, 1997. Resumos. Salvador:SBF, 1997. p.237.

YAMAUCHI, T.; HARA, T.; SONODA, Y. Effects of boron deficiencies and calcium supply on the calcium metabolism in tomato plant. Plant and Soil, v.93, n.223/231, 1986. 